${ }^{1}$ Department of Systematic Zoology, Evolutionary Biology Centre, Uppsala University, Uppsala, Sweden (Present address);

${ }^{2}$ Departamento de Biodiversidad y Biología Evolutiva (Entomología), Museo Nacional Ciencias Naturales, Madrid, C.S.I.C., Spain

\title{
First phylogenetic analysis of the subfamily Pachydeminae (Coleoptera, Scarabaeoidea, Melolonthidae): the Palearctic Pachydeminae*
}

\author{
I. SANMARTín ${ }^{1,2}$ and F. MARtín-Piera ${ }^{2}$
}

\begin{abstract}
This paper presents the first phylogenetic analysis of Pachydeminae Reitter, 1902; one of the least known subfamilies of Melolonthidae, 'leafchafers' (Scarabaeoidea, Coleoptera). Some species of Pachydeminae have recently become agricultural pests in southern Spain. We analysed the phylogenetic relationships among 49 species belonging to 16 genera in the Palearctic region, based on a set of 63 morphological characters from the adult external morphology, wing anatomy, mouthparts and male and female genitalia. The last three sets of characters are described here for the first time. The phylogeny shows that the Palearctic Pachydeminae are monophyletic within the subfamily. Mouthparts and male and female genitalia provide the best synapomorphies for intergeneric relationships. In contrast, most of the external morphological characters used in the taxonomy of Pachydeminae are highly homoplastic. The phylogeny shows a basal split between the genera Hemictenius Reitter, 1897; Pachydema Castelnau, 1832, and the monospecific Peritryssus Reitter, 1918; and a second clade including the rest of genera. The remarkable Peritryssus is confirmed as a Pachydeminae, being the sister group to the monophyletic Hemictenius. Except for the position of P. rubripennis (Lucas, 1848) and P. zhora Normand, 1951, the phylogeny supports the monophyly of Pachydema but rejects the traditional division into species groups and the monophyly of the endemic Canarian species. In contrast, Tanyproctus Faldermann, 1835, must be rejected as polyphyletic. Otoclinius Brenske, 1896, is also probably polyphyletic (two new species synonymies), whereas Leptochristina Baraud and Branco, 1991, is either mono- or paraphyletic. The two Mediterranean genera Ceramida Baraud, 1897, and Elaphocera Gené, 1836, form a monophyletic group, this clade being the best supported by the data set. Ceramida is clearly monophyletic, whereas Elaphocera is probably monophyletic except for E. barbara Rambur, 1843, which shares with Ceramida the character state for numerous mouthpart and genitalic characters. The phylogeny questions the generic status of the small and monospecific genera of Pachydeminae. The monotypic Alaia Petrovitz, 1980, and Brenskiella Berg, 1898, are merged with Europtron Marseul, 1867, into one clade, whereas Atanyproctus Petrovitz, 1954, is grouped with some species of Tanyproctus, and the monotypic Pachydemocera Reitter, 1902, is proposed as a junior synonym of Elaphocera.
\end{abstract}

Key words: Pachydeminae - Melolonthidae - Coleoptera - leaf-chafers - Palearctic - phylogeny - mouthparts - wing anatomy - internal genitalia

\section{Introduction}

The Scarabaeoidea is one of the largest and best-studied superfamilies of Coleoptera. It has traditionally been classified into two ecological groups: the Laparosticti (dung beetles) and the Pleurosticti (leaf-feeding beetles or leaf chafers). The phylogeny of the Laparosticti is relatively well known (Holloway 1960; Howden 1982; Scholtz 1986; Scholtz et al. 1987, 1988; Zunino 1984a), whereas the Pleurosticti, especially the most derived families, are far from resolved. Melolonthidae is an especially poorly defined family, comprising numerous subfamilies of uncertain status (Scholtz 1990; Browne and Scholtz 1998). However, the family is economically important because the larvae ('white grubs') are pests of crops and underground stems of plants (Ritcher 1966).

Pachydeminae Reitter, 1902, is one of the least known subfamilies of Melolonthidae. Its species were not considered important for agriculture (Balachowsky 1962) until 1995, when Ceramida Baraud, 1987 was reported as a new pest of olive trees in southern Spain (Alvarado et al. 1996; Serrano et al. 1996; Sanmartín and Martín-Piera, in prep.). The Pachydeminae comprise about 115 genera and 530 species worldwide, although there is not a definitive catalogue (Lacroix 2000). They are distributed in all major zoogeographical regions except India and Australia but their distribution is very

\footnotetext{
*The second author of this paper, my thesis advisor and my good mentor, Fermín Martín-Piera, died shortly after this paper was accepted. This paper is dedicated to his memory (I. Sanmartín).
}

disjunct. In the Holarctic region, they are present in western North America and the southern Palearctic, with an east-west Mediterranean disjunction well known in other groups of animals (Oosterbroek and Arntzen 1992). In the Neotropics, the Pachydeminae are restricted to the temperate region (Bolivia, Peru, Uruguay but mainly Argentina and Chile). They are also more abundant (both in number of species and genera) in the south-east part of the Afrotropical region (Lacroix 2000). These disjunct distributions, together with the reduced geographic ranges of most species (females are usually flightless), make the subfamily Pachydeminae especially interesting for biogeographic analysis.

The Palearctic Pachydeminae comprise about 20 genera and 280 species, although there is no definitive inventory (Baraud 1992; Lacroix 1993; Piattella and Sabatinelli 1996; Lacroix 2000). The Palearctic region is the best-represented in terms of number of species, whereas the Afrotropical region leads in number of genera. Five out of the eight genera of Pachydeminae that include more than 10 species are Palearctic (Ceramida, Elaphocera Gené, 1836; Hemictenius Reitter, 1897; Pachydema Castelnau, 1832;, Tanyproctus Faldermann, 1835). The Palearctic Pachydeminae are distributed across southern Eurasia from the Canary Islands to China, including southern Europe (except France and Italy), North Africa, Near East, Asia Minor, Iran, Afghanistan, Caucasus, and Central Asia (see Appendix). Most species are distributed in the south-west Palearctic (west of the Ural Mountains) with the eastern Palearctic represented by only 10 species in China and one in Burma (Lacroix 2000). 
The taxonomy of the Palearctic Pachydeminae is particularly difficult. The paucity of specimens in entomological collections has hampered the establishment of character variability, and has led to the description of new taxa on specimen or interpopulation differences (Sanmartín and Martín-Piera 1999a). In addition, identification rests exclusively on characters of the male external morphology because females are difficult to collect and have only been described for a few species of the largest genera. However, most species of Pachydeminae present an accentuated sexual dimorphism. Females are characterized by a massive abdomen, reduced legs and antennae, and variable wing reduction. These traits are probably adaptations to fossorial life because, after emerging in the autumn, females dig into the ground for oviposition in the spring (Sanmartín and Martín-Piera 1997; in prep.). Most of the characters used in the identification of genera (related to the male external morphology) are not good candidates for synapomorphies because either they vary within the genus (polymorphic) or are also present in other genera (symplesiomorphies). This is especially so in the larger and more geographically widespread genera Tanyproctus and Pachydema. One consequence of this lack of reliable characters is the tendency in the taxonomy of Pachydeminae to create new genera that are either monotypic or contain a few species. About $62 \%$ of the genera of Pachydeminae contain only one species (Lacroix 2000). Most of the monotypic genera have been erected to accommodate single species that differ from traditional genera by a conspicuous autapomorphy. Some of them are potentially ingroup members of other, larger genera. Thus, among the 20 Palearctic genera, nine are monotypic (Alaia Petrovitz, 1980; Brenskiella Berg, 1898; Buettikeria Sabatinelli and Pontuale, 1998; Jalalabadia Balthasar, 1967; Kryzhanovskia Nikolajev and Kabakov, 1977; Pachydemocera Reitter, 1902; Peritryssus Reitter, 1918; Pseudopachydema Balthasar, 1930; Tanyproctoides Petrovitz, 1971), six comprise less than nine species (Asiactenius Nikolajev, 2000; Atanyproctus Petrovitz, 1954; Europtron Marseul, 1867; Leptochristina Baraud and Branco, 1991; Otoclinius Brenske, 1896; Phalangonyx Reitter, 1889), and only five include more than 10 species (Ceramida, Elaphocera, Hemictenius, Pachydema and Tanyproctus). Furthermore, all new genera established in the last 10 years are either monotypic or contain less than six species (e.g. Alaia, Asiactenius, Buettikeria, Leptochristina).

Another problem in the systematics of the Palearctic Pachydeminae is the lack of a comprehensive taxonomic study. Except for Baraud's monograph (Baraud 1992) of the western Palearctic genera, there are only a few studies dealing with small genera (Branco 1981; Nikolajev 1987; Baraud 1991; Baraud and Branco 1991; Bezdek et al. 1999). Baraud's classification (Baraud 1992) of the western Palearctic Pachydeminae is based on a few unreliable morphological characters, and the monophyly of the most speciose genera Tanyproctus and Pachydema has not been established. Discussion of phylogenetic relationships among the Palearctic genera or even within the entire subfamily has never been attempted.

In this work, we attempt to redress this situation by presenting the first cladistic analysis of the subfamily Pachydeminae based on a complete new set of characters. We analysed relationships among 49 species belonging to 16 Palearctic genera (including the five largest, most speciose genera) based on a set of 63 characters. A main objective of the paper is to describe three new sets of characters that could be useful in the identification and diagnosis of genera: mouthpart structures, wing anatomy, and male and female genitalia. We compared the value as putative synapomorphies of these new characters with the male external morphologic characters currently employed in the taxonomy of Pachydeminae. A second objective was to test the monophyly of the Palearctic genera which might help to advance the reconstruction of a phylogenetic system for the entire subfamily.

\section{Materials and methods}

Prior to the cladistic analysis, we carried out a comparative study on the adult morphology of Pachydeminae, including external morphology, mouthparts, wing anatomy, and male and female genitalia (Sanmartín 1998; Sanmartín and Martín-Piera 1999a). We examined 125 species (more than 2000 specimens) belonging to 14 Palearctic genera: Alaia, Atanyproctus, Brenskiella, Ceramida, Elaphocera Europtron, Hemictenius, Leptochristina, Otoclinius, Pachydema, Pachy democera, Peritryssus, Tanyproctoides and Tanyproctus (see Appendix for a complete list of the species studied and their distribution). This represents approximately $45 \%$ of the total number of species in the Palearctic region and an average of $78.5 \%$ species studied per genus, ranging from $100 \%$ (e.g. Ceramida and Elaphocera) to $21 \%$ in Tanyproctus (Appendix).

For the study of anatomical structures, specimens were relaxed in boiling distilled water. Mouthparts were studied under immersion in $70 \%$ ethanol and fixed to a label pinned to the specimen. The study of wing anatomy followed Browne and Scholtz (1994): the left wing was removed at the tergum, spread on a microscope slide with a drop of $70 \%$ ethanol, and held outstretched until the ethanol evaporated; once fixed, the wing was mounted in Euparal ${ }^{\circledR}$ mounting medium (Euparal R1344. Agar Scientific, Ltd. Essex, UK). For the study of male genitalia, the aedeagus was removed through the pygidium and cleared alternatively in boiling distilled water and a $5 \% \mathrm{KOH}$ solution (CocaAbia and Martín-Piera 1991). The endophallus was extracted through the apical ostium of the parameres, dehydrated through a progressive dehydration alcoholic series ending in xylol, and mounted on a microscopic slide in DPX ${ }^{\circledR}$ mounting medium (DPX 360294H. BDH Laboratory Supplies, Poole, UK). To study the microsensilla of the endophallus, the endophallus was dehydrated, air-dried (instead of critical point dried), sputter-coated with gold and examined under the scanning electron microscope. For the study of female genitalia, the complete abdomen was removed and cleared prior to the dissection and the genitalia was mounted either on an excavated slide with Euparal $^{\circledR}$ or stored in microvials with $70 \%$ ethanol. The latter technique was more useful to fully appreciate the three-dimensiona disposition of the structures. Illustrations were made using a camera lucida attached to a Wild stereomicroscope, and a video camera was used for both viewing and photographing finer details (Wild MZ.8. Leica Microsystems, Barcelona, Spain).

\section{Cladistic analysis}

Taxa studied

We included in the analysis 49 species representing 16 Palearctic genera of Pachydeminae (Table 1). Apart from the 14 genera mentioned above, we coded the monotypic Kryzhanovskia and Pseudopachydema directly from the original descriptions because we could not access the material of the type species. The other Palearctic genera not included in the analysis (Lacroix 2000) are all monotypic or small, recently described genera. Jalalabadia (one species from Afghanistan) is a mysterious genus that has never been cited after the original description (Lacroix, pers. comm) but seems to be close to Tanyproctoides. Buettikeria includes one species from the Arabian Peninsula and its range of distribution borders the Palearctic. Phalangonyx (eight species from Saudi Arabia, Iran and Afghanistan) has a complicated taxonomic history. Reitter (1889) erected this genus to separate $T$. coniceps from other Tanyproctus species based on the strongly sinuated clypeus margin, but he relegated Phalangonyx to a subgenus of Tanyproctus in a subsequent work (Reitter 1902). Since then, it has been considered either as a subgenus of Tanyproctus (Medvedev 1952), as a junior synonym of this last genus (Petrovitz 1968; Baraud 1992), or a as a different genus 
Table 1. Species included in the phylogenetic analysis and their geographic distribution. Abbreviations for the subgenera (see text). (B): Brachydema; (T): Tanyproctus sensu stricto; (Tca.): Tanyproctocera; (A): Artia; (P): Pachydema sensu stricto; (S): Sparophysa

Genus Species Geographic distribution

Palearctic

Otoclinius Brenske, 1896

O. fragilis Petrovitz, 1980

O. gracilipes Brenske, 1896

P. lucidicollis (Kraatz, 1882)

L. pubimargo (Reitter, 1902)

L. annamariae Baraud \& Branco, 1991

T. (B.) reichei (Rambur, 1843)

T. (T.) rufidens (Marseul, 1879)

T. (B.) kindermanni (Reiche, 1861)

T. (T.) bucharicus (Reitter, 1897)

T. (T.) subciliatus Reitter, 1902

T. (Tca.) saulcyi (Reiche, 1856)

T. (B.) rugulosus Fairmaire, 1892

T. (T.) ganglbaueri (Brenske, 1897)

T. (T.) persicus (Ménétries, 1832)

Pachydema Castelnau, 1832

Hemictenius Reitter, 1897

Elaphocera Gené, 1836

Ceramida Baraud, 1987

Europtron Marseul, 1867

Peritryssus Reitter, 1918

Brenskiella Berg, 1898

Alaia Petrovitz, 1980

Tanyproctoides Petrovitz, 1971

Atanyproctus Petrovitz, 1954

Pseudopachydema Balthasar, 1930

Kryzhanovskia Nikolajev \& Kabakov, 1977

Non-Palearctic

Sparrmannia La Porte, 1840

Phobetus Le Conte, 1856

Outgroups

Euserica Reitter, 1896

Melolontha Fabricius, 1775

Pseudotrematodes Jaquelin du Val, 1860

Polyphylla Harris, 1842
P. castanea (Brullé, 1838)

P. obscura (Brullé, 1838)

P. bipartita (Brullé, 1838)

P. tinerfensis Galante \& Stebnicka, 1992

$P$. (A.) anthracina Fairmaire, 1860

P. (P.) hirticollis (Fabricius, 1787)

P. (P.) xanthochroa Fairmaire, 1879

P. (S.) palposa Reitter, 1902

$P$. (A.) rubripennis (Lucas, 1848)

P. (A.) zohra Normand, 1951

H. tekkensis (Reitter, 1889)

H. ochripennis Reitter, 1902

H. opacus

H. simplicitarsis Reitter, 1897

H. opacipes Reitter, 1902

H. nigrociliatus Reitter, 1897

E. elongata Schauffus, 1874

E. syriaca Kraatz, 1882

E. emarginata (Gyllenhal, 1817)

E. capdeboui Schauffus, 1882

E. barbara Rambur, 1843

E. sulcatula Fairmaire, 1884

E. carteiensis Rambur, 1843

E. alonsoi López-Colón, 1992

C. bedeaui (Erichson, 1840)

C. baraudi (Branco, 1981)

E. gracile Marseul, 1867

P. excisus Reitter, 1918

B. flavomicans (Brenske, 1896)

A. sexdentata Petrovitz, 1980

A. miksici Petrovitz, 1965

A. simplicitarsis Petrovitz, 1954

P. caucasica Balthasar, 1930

K. olegi Nikolajev \& Kabakov, 1977

S. alopex (Fabricius, 1787)

P. comatus Le Conte, 1856

E. mutata (Gyllenhal, 1817)

M. papposa Illiger, 1803

$P$. friwaldskii (Menétriès, 1836)

P. fullo (Linnaeus, 1758)
T. arabicus (Arrow, 1932)
Iran

Iran

Rhodes, Syria

Syria; Turkey

Iraq

Greece; Asia Minor

Caucasus, Iran

Syria; Israel

Buchara, Afghanistan

Turkestan

Israel; Syria

Syria; Turkey

Iran; Transcaspia

Iran, Caucasus

Canary Islands (Tenerife), Gormera

Canary Isl (Tenerife) Gormera, Fuerteventura

Canary Isl (Gran Canaria, Tenerife, Gomera) Lanzarote, Hierro

Canary Isl (Tenerife)

Morocco

Algeria; Tunis; Libya

Tunis

Egypt

Morocco; Algeria

Tunis; Libya

Transcaspia; Turkestan;

Baldschuan; Tadzhikistan

Buchara; Samarcanda (Ball., 1870)

Afghanistan; Buchara

Buchara, Uzbekistan

Buchara, Uzbekistan

Greece; Turkey

Syria; Crete

Sardinia

Balearic Islands

Morocco; Algeria

Morocco

SE Iberian Peninsula

SE Iberian Peninsula

S Iberian Peninsula; Morocco; Algeria

Portugal

Algeria

Sicilia

Israel

Iran; Afghanistan

Saudi Arabia

Afghanistan

Iran

Caucasus, Azerbaïdjan

Afghanistan

South Africa

California

Iberian Peninsula, Morocco

Iberian Peninsula

Balkans, Asia Minor

$\mathrm{W}$ and $\mathrm{C}$ Europe, Russia, Caucasus,

North Africa, Asia Minor

Syria 
(Arrow 1932; Decelle 1982; Sabatinelli and Pontuale 1998). Finally, Nikolajev (2000) recently described the new genus Asiactenius (northern Iran and Afghanistan, southern Turkmenistan) to include two new species, A. mirabilis and A. afghanus and three species previously assigned to Hemictenius, H. reitteri Medvedev, 1952, H. tekkensis (Reitter, 1889) and H. tokgagevi Medvedev, 1962. Asiactenius differs from Hemictenius in the basal enlargement of the male meso- and metartarsal claws. This genus is represented in the analysis by H. tekkensis, which in our analysis was included within Hemictenius.

The non-monotypic genera were represented in the analysis by a comprehensive sample of species reflecting their morphological diversity and geographic distribution. Using species as terminal taxa in the analysis instead of genera permitted to evaluate the monophyly of the genera but also to avoid polymorphism (missing data) in the terminals (Nixon and Davis 1991). Polymorphism was especially important in the case of the larger and more geographically widespread genera Tanyproctus and Pachydema, which usually present more than one state for the external morphological characters. The alternative approach of inferring the ancestral (groundplan) state of the genus from a previous phylogeny (Ronquist 1995; Nordlander et al. 1996; Morrone 1997) was not feasible because this is the first phylogeny on Pachydeminae. Another advantage of using species as the phylogenetic unit in the analysis is that we could examine the phylogenetic position (generic status) of the monotypic and smallest genera of Pachydeminae (e.g. Pachydemocera), and also check the classification of some 'problematic' species that differ morphologically from the genera in which they are currently included (e.g. Tanyproctus reichei (Rambur, 1843) Pachydema zhora Norman, 1951; Elaphocera barbara Rambur, 1843). We could also test the phylogenetic support for the internal classification of the largest, most speciose genera Tanyproctus and Pachydema. These genera have been divided into species groups or subgenera according to characters of the external morphology. Tanyproctus is traditionally classified into four subgenera (Baraud 1992): Brachydema Fairmaire, 1884; Tanyproctus s. str. Faldermann, 1835; Tanyproctocera Reitter, 1902; and Tetraproctus Khnzorian, 1953. Similarly, the African species of Pachydema are classified into four species-groups/subgenera (Baraud 1985): Pachydema s. str. Castelnau, 1832; Artia Rambur, 1843; Sparophysa Burmeister, 1885 and Phygotoxeuma Brenske, 1897. The 16 endemic species of Pachydema in the Canary Islands (Lacroix 2000) are usually considered as a different species-group. In order to test the phylogenetic support of these internal classifications, one or two species for each species group/ subgenus were included in the analysis, with the exception of Phygotoxeuma and Tetraproctus, for which we could not study any specimen. Four Canarian species were also included within Pachydema to test whether they form a monophyletic group within the genus.

\section{Outgroup}

Characters were polarized using the subfamily Melolonthinae as the main outgroup. Although the phylogeny of Melolonthidae has not yet been established (Browne and Scholtz 1998), the subfamily Melolonthinae is traditionally considered as closely related to Pachydeminae (Baraud 1992; Lacroix 2000). In addition, the Palearctic genera of Melolonthinae have recently been the subject of a complete taxonomic and phylogenetic revision that included many characters herein analysed (Coca-Abia 1995). Instead of treating Melolonthinae as a single taxon, we selected some species to represent the morphological variability within the subfamily. This was done in order to avoid terminal polymorhism in the outgroup but also to resolve ambiguous character polarizations when the outgroup presents more than one ingroup state. In that case, characters informative about ingroup relationships might also help to resolve relationships among outgroup representatives (Clark and Curran 1986). Two species were selected from each of the two tribes of Melolonthinae (Coca-Abia 1995): Melolontha papposa Illiger, 1803, and Polyphylla fullo (Linnaeus, 1758) from Melolonthini, and Pseudotrematodes friwaldskii (Menétriès, 1836) and Aplidia akbesiana Petrovitz, 1971 from Rhizotrogini (Table 1). These genera are placed basally in the phylogeny of each tribe (Coca-Abia 1995) and thus probably reflect more accurately the morphological groundplan of the tribe than more derived genera (Ronquist 1995). Using these basal genera permits also to avoid the problem of 'inapplicable' characters in the matrix (Maddison 1993).
For example, the genitalic structure of 'temones' is a primitive feature of Rhizotrogini (Coca-Abia 1995), which is present in the basal genera but absent from the more-derived genera (e.g. Rhizotrogus Berthold, 1827).

To help resolve ambiguous character polarizations we also included a representative of the related subfamily Sericinae (Euserica mutata (Gyllenhal 1817)) as a second outgroup. In some recent classifications (Lacroix 2000), Sericinae is considered as a separate family from Melolonthidae. Finally, since no phylogeny has been proposed for the Pachydeminae, we included two non-Palearctic genera in the analysis in order to test the monophyly of the Palearctic genera within the subfamily. The Nearctic genus Phobetus Le Conte, 1856 (P. comatus Le Conte, 1856) and the Afrotropical genus Sparrmannia La Porte, 1840 (S. alopex (Fabricius 1787)) were selected because these two genera (and Aegostetha Dejean, 1833) are the only non-Palearctic genera that include more than 10 species (Phobetus: 12 spp., Sparrmannia: 27 spp.).

\section{Characters}

Sixty-three characters were coded for the analysis (Table 2), divided into external morphology (22 characters), mouthparts (eight), wing anatomy (three) and male and female genitalia (30). Many of the ingroup species were not scored for the female characters (state 'missing') because females have only been described in a few species of the largest genera Ceramida, Elaphocera, Hemictenius, Pachydema and Tanyproctus. Similarly, the outgroup species could not be scored for several characters of the male internal genitalia because of difficulties with assessing the homologies (state 'non-applicable'). The morphology of the structures in the outgroup was very different to those in the ingroup and comparison was not possible (e.g. ch49). In both cases, 'missing' and 'non-applicable', the character states were coded as '?' (Table 2). Multistate characters (26) were considered as ordered (Farris 1970) if the states seemed to follow a natural sequence (morphocline): e.g. a measurement ratio (character 47) or the progressive reduction of the functionality of the female wing (ch33). The transformation series was hypothesized to be $0-1-2$. If the states could not be unambiguously ordered, the character was considered as unordered (Fitch 1971): e.g. characters describing shape (ch42, ch50).

\section{Analysis}

Cladistic analyses were carried out using the parsimony program NONA version 2.0 (Goloboff 1998). The search strategy used TBR (Tree Bisection and Reconnection) branch swapping on a series of 1000 random addition replicates retaining up to 10 cladograms per replicate $(\mathrm{h} / 10$; mult*1000). The shortest trees found on each replication were swapped to completion using the $\left(\max ^{*}\right)$ option. This strategy retained up to 10000 trees in the buffer. The high number of trees probably indicates the existence of numerous tree islands. In order to search the tree space more efficiently, we used the Parsimony Ratchet search (Nixon 1999) implemented in NONA and WINCLADA version 0.9 (Nixon 2000). In this search, a starting tree is generated followed by branch-swapping (TBR). Then, a random subset of six characters $(10 \%$ of the data set) is selected and weighted double. The reweighted matrix is used to perform branch-swapping (TBR) on the first tree, keeping only one tree. All characters are set to the original (equal) weights and TBR is performed on the second tree until an optimal tree is found. This was repeated 200 times (iterations). The Parsimony Ratchet was developed in order to maximize the number of starting points on each search, i.e. the number of tree islands visited and reduce the time of search spent on each tree island (by retaining a smaller number of trees), while at the same time retaining the tree structure already attained. Because the ratchet samples many tree islands with fewer trees from each island, it provides much more accurate estimates of the true consensus that collecting many trees from few islands (Nixon 1999). Character changes were mapped on the trees using WINCLADA vs. 0.9.

\section{Results}

\section{Character analysis}

Because most characters used in the analysis are described here for the first time or largely reinterpreted, we give a detailed 
Table 2. Data matrix of 56 taxa $\times 63$ characters used to reconstruct the phylogeny of the Palearctic Pachydeminae. '?': state unknown or not applicable

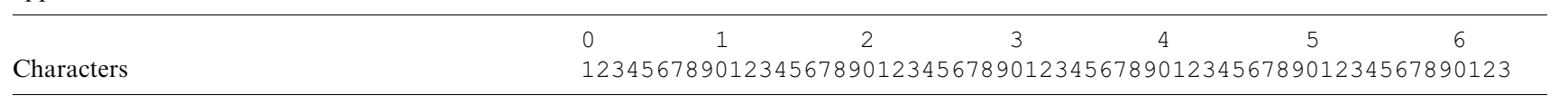

\section{Outgroups}

E. mutata

M. papposa

P. friwaldskii

Po. fullo

A. akbesiana

Non-Palearctic

Sp. alopex

$P h$. comatus

Palearctic

O. fragilis

O. gracilipes

Pc. lucidicollis

L. pubimargo

L. annamariae

T. reichei

T. rufidens

T. kindermanni

T. bucharicus

T. subcialiatus

T. saulcyi

T. rugulosus

T. ganglbaueri

T. persicus

$P$. castanea

P. obscura

$P$. bipartita

$P$. tinerfensis

$P$. anthracina

$P$. hirticollis

P. xanthochroa

P. palposa

P. rubripennis

P. zhora

H. tekkensis

H. ochripennis

H. opacus

H. simplicitars

H. opacipes

H. nigrociliatus

E. elongata

E. syriaca

E. emarginata

E. capdeboui

E. barbara

E. sulcatula

E. carteiensis

E. alonsoi

C. bedeaui

C. baraudi

Eu. gracile

Pe. excisus

B. flavomicans

A. sexdentata

Td. arabicus

At. miksici

At. simplicitars

Ps. caucausica

K. olegi
0002011120001010100011110010010000011000 ? 3110?????? 112? 00000 ?? 2 $0301000010111000000000000000000000200000 ? 1100020$ ?? 001110000210 0000000000000000000000000000000020010000 ? 0000100 ??? 0? 000000???? 0301011110011000000000000000000000200000 ? 1010020??? 10111100???? $0000010101101100100000000000000000000000 ? 0011 ? ? 3 ? ? ? ? 00110001 ? ? ?$

13010101011100101000 ? $0000000000 ? 021001100000110$ ?????????????? 0002011 0 $01101 ? 100$ ? 01 ? $00001001 ? ? 32121101110010$ ???????????????

010001101010001100211 ? $1120022100 ? 120101002101001100$ ??????????? 010200000000001100201 ? $1120112100 ? 120101012101001100$ ???????????? 131100111000001100101 ? 1010112122 ? 111111022121021220 ?? ?? ?????? 130110101100001100211 ? 1010111101 ? 120101002111000000 ?????????? 130111000100101100211 ? 1010111101 ? 120101002111000000 ? ? ?? ?????? 010201101100001100211100001000002120101011100001100111210000302 $01020110110000110020100010111100 ? 120101011101001100$ ?? ????????? 010201101100001100211 ? 00? 01? ? 00? 120101011001001100 ?? ?? ?? ?? ? $01020110110000110020100010111100 ? 120101011101001100$ ???????????? 010201100100001100211000101111 ?? 2120101011101001100111202100002 $01020000011110110021100010111100 ? 120101002101001100$ ?? ????????? 010201101100001100211000101111 ?? 120101011101001100 ?? ???????? 010201101000001100201100101111002120101011101001100 ??????????? 010201100100001100211 ? $0010111100 ? 120101011101001100$ ???????????? 010201100101101100211100 ? 00000 ?? 120101010000002101 ?????????? $010201100101001100211 ? 0000000022 ? 120101011100002101$ ???????????? 010201100101101100211100000000220120101010100002101 ??????????? 010201100101101100211 ? 0000000022 ? 120101011100002101 ?? ???????? 010201100101101100211100000000220120101010100002101101210000002 010201100101101100211100000000 ?? 120101011100002101 ?? ?? ?????? 010200000101001100211100000000220120101011100002101100210000002 01020000010110110021110000000022 ? 120101011100002101 ?? ????????? $01000010010000110021110000000000 ? 120101011100002101$ ??????????? 110000100100001100211 ? $0010011100 ? 120101012000002101$ ?? ?? ??????? $011001101100001100211100000000003120101010000002101110211100 ? 02$ $011001101100001100001 ? 0000000000 ? 120101010000002101$ ??????????? 011001101100001100211100000000003120101010000002101100211200002 01100110110000110000110000000000 ? 120101010000002101 ???????????? 011001101100001100211100 ? 00000 ? 3120101010100002101100211200002 011001101100001100211100 ? 0000000 ? 120101010000002101 ?? ?? ?????? 130100011100101100001010101111011111111022021020030010102210101 13010001110010110000101010111101 ? 110011022021010030 ? ? ?? ?? ???? 13010001110011110000101010111101 ? 111111022021010030 ?? ????????? 130100011100111100001000101111011111111022121010030010102210101 13010001110010110000101020111101 ? 110011032121000030 ?? ?? ?????? 13110001011110110000100010111101 ? 111111022121020030 ?? ????????? 13010001011110110010100010111101 ? 111111022121020030 ?????????? 130100010101111100101000101111011111111022121020030010102210101 13010 ? 011100101111001011211231013200011032011100010010102101210 130100111100101111001011211231013201011032011100010010100101210 110001101000001110002 ? 11? 0023100? 120101112001002102 ? ? ? ???????

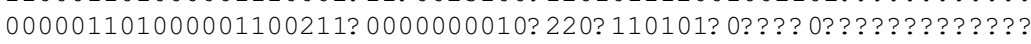
010000000110001110212 ? $1010011100 ? 120101112001001100$ ??????????? 0102011001000011 ? 0211 ? 1020012100 ? 1201010120 ? 1003043 ? ?? ????? ?? 020210000100001100211 ? $1010111100 ? 120101002101001100$ ?? ?? ??? ?? ? $010201101000001100001 ? 1020111100 ? 120111012100002103$ ? ????????? $010201101000001100001 ? 0020111100 ? 120111011101001100$ ?? ?? ?? ?? ??

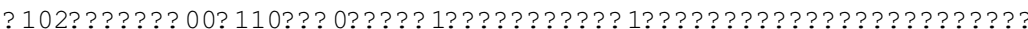
0202000 ? 01100 ? 11? 2 11 ? ? ? 01? ? ? ? ? 11 ? 1? 121? ? ? ? ? ? ? ? ? ? ? ? ? description of each character, instead of a mere list. Only some indication of the distribution of character states across taxa is given in the descriptions. For more information, the data matrix should be consulted. Terminology for wing structures follows Browne and Scholtz (1994) and Kukalova-Peck and Lawrence (1993); terms for mouthparts and genitalia are from Nel and Sczholtz (1990) and d'Hotman and Scholtz (1990a,b), respectively. 


\section{A External morphology}

1 Shape of clypeus

(0) Polygonal (Fig. 1); (1) Rounded (Fig. 2). The clypeus is typically polygonal in both Pachydeminae and the outgroups. A rounded clypeus is only found in Ceramida, Elaphocera, Pachydemocera, Leptochristina, Europtron and Sparrmannia.

2 Number of segments in male antennal club

(0) Three; (1) Five; (2) Six; (3) Seven. A three-jointed antennal club seems to be the ancestral condition in Scarabaeoidea (sensu Scholtz et al. 1994). Among the outgroups, it is present in Euserica, Pseudotrematodes and Aplidia, whereas Melolontha and Polyphylla present a five-segmented club. It also varies considerably in the Palearctic Pachydeminae. Except for Peritryssus with a three-jointed club, the rest of genera have five (e.g. Pachydema), six (Tanyproctoides) or seven (e.g. Ceramida) segments in the club. In contrast, a three-segmented club is the generalized condition among the Nearctic Pachydeminae (e.g. Phobetus), and it is also common in the Neotropical Pachydeminae (Martínez 1958, 1975; Lacroix 2000). This character was coded as unordered because it does not follow a natural sequence within Scarabaeoidea, i.e. some families present genera with three or five segments but not the intermediate state of four (Scholtz 1990).

3 Relative length of the first segment of male antennal club (0) Approximately the same length than the rest of segments (Fig. 4); (1) Approximately half the length of the rest of segments (Fig. 3). Baraud (1992) used this character to separate Hemictenius from Pachydema. All the outgroups and most genera of Pachydeminae present a first segment about as long as the rest of the segments. The apomorphic state is only found in Pachydemocera, Hemictenius and some species of Elaphocera (E. sulcatula Fairmaire 1884).

4 Shape of last segment of antennal funicle

(0) 'Cup'-shaped (Fig. 3); (1) 'Stick'-shaped (Fig. 5); (2) Applied to the club (Fig. 4). This character varies considerably in both Pachydeminae and the outgroups. For example, the segment is cup-shaped in Pseudotrematodes and Aplidia, sticklike in Polyphylla and Melolontha, and applied in Euserica. A similar character is employed in identification keys (Baraud 1992) to distinguish Pachydema (funicular segment short and applied to the club) from Tanyproctus (funicular segment long and not applied). However, the funicular segment is applied to the club in both Pachydema and Tanyproctus, whereas the length of the segment varies strongly among the species and is therefore not a good generic character. Unordered.

5 Position of last funicular segment relative to antennal club (0) Near the base of the club (Fig. 4); (1) Far from the base of the club (Fig. 6). All outgroup representatives and nearly all Pachydeminae present the last funicular segment near the base of the club. Only Tanyproctoides and Leptochristina present the derived state 1. Baraud and Branco (1991) used this character to separate Leptochristina (state 1) from Pachydemocera (state 0).

\section{Pubescence on clypeus}

(0) Present; (1) Absent. This pubescence refers exclusively to trichoid setae, the scale-shaped setae of Polyphylla and Melolontha not being considered. All characters related to external pubescence are very variable within both the outgroup and the Pachydeminae. For instance, among the Melolonthinae, Melolontha (Melolonthini) and Pseudotrematodes (Rhizotrogini) present pubescence, whereas Polyphylla (Melolonthini) and Aplidia (Rhizotrogini) do not. Euserica is also pubescent.

7 Pubescence on frons

(0) Present; (1) Absent.

8 Pubescence on anterior inner margin of clypeus

(0) Present; (1) Absent. Baraud and Branco (1991) used this character to separate Leptochristina (state 0) from Pachydemocera (state 1).

9 Pubescence on anterior margin of pronotum

(0) Present; (1) Absent.

10 Pubescence on posterior margin of pronotum

(0) Absent; (1) Present.

11 Pubescence on surface of pronotum

(0) Absent; (1) Present.

12 Ridge on anterior margin of pronotum

(0) Present; (1) Absent.

13 Ridge on posterior margin of pronotum

(0) Present; (1) Absent.

\section{Shape of metacoxae}

(0) Not pointed (Fig. 7); (1) Pointed (Fig. 8). The not pointed metacoxa is the most widespread condition in Pachydeminae and the outgroups. A pointed metacoxa is only present in Aplidia and some species of Elaphocera.

\section{Abdominal sternites}

(0) Fused at middle (Fig. 9); (1) Not fused at middle (Fig. 10). This character has traditionally been used to distinguish Melolonthinae from the rest of subfamilies of Melolonthidae (Baraud 1992). All Pachydeminae and Sericinae present sternites not fused at the middle.

\section{Fifth and sixth abdominal sternites separated} by a thick membrane

(0) Absent (Fig. 9); (1) Present (Fig. 10). A thick membrane between the fifth and sixth sternites is generally considered as a synapomorphy of Pachydeminae (Baraud 1992; Lacroix 2000). Neither the Melolonthinae nor the Sericinae present this membrane. However, whereas the membrane is clearly present in all Palearctic genera, it is not so clear in the non-Palearctic genera. We have observed this membrane neither in Sparrmannia nor in Phobetus, although Lacroix (pers. comm.) suggests that the membrane of Nearctic and Afrotropical genera is hidden by the mobile sternites of the pygidium. It should be noted however, that most descriptions of genera in the literature fail to notice the existence of this membrane. We thus decided to code Sparrmannia and Phobetus as lacking this membrane.

17 Position of inner spine of fore tibiae

(0) Behind the second outer tooth (Fig. 11); (1) Ahead or in front of the second outer tooth (Fig. 12). As in most families of 

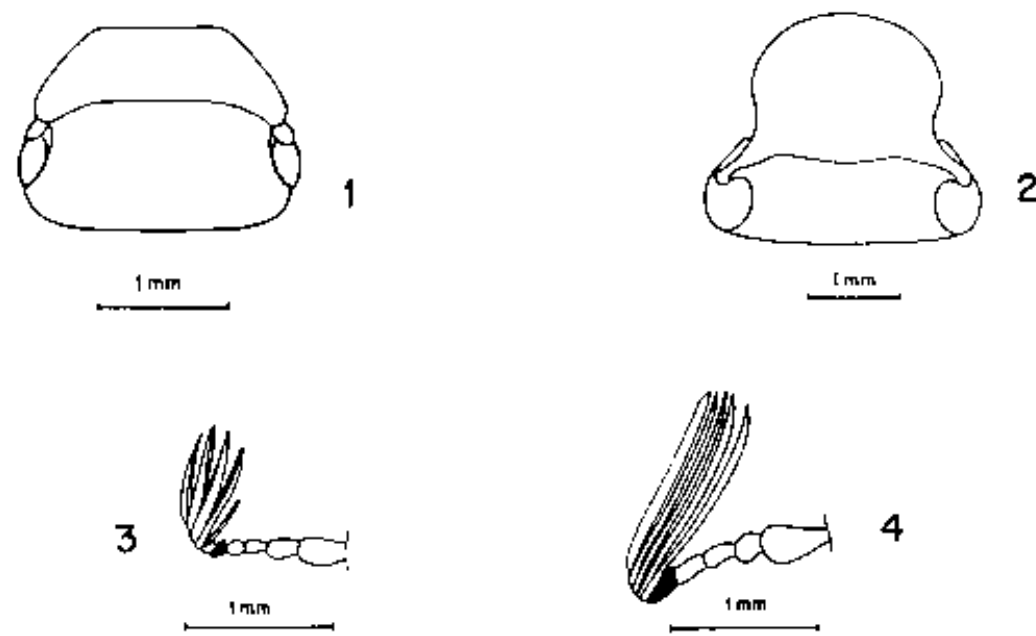

4

3

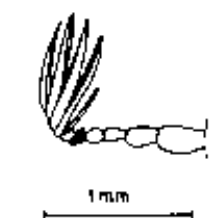

5

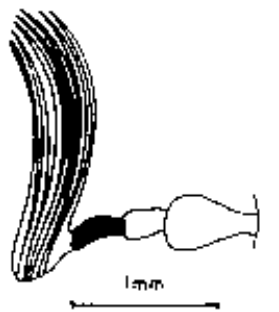

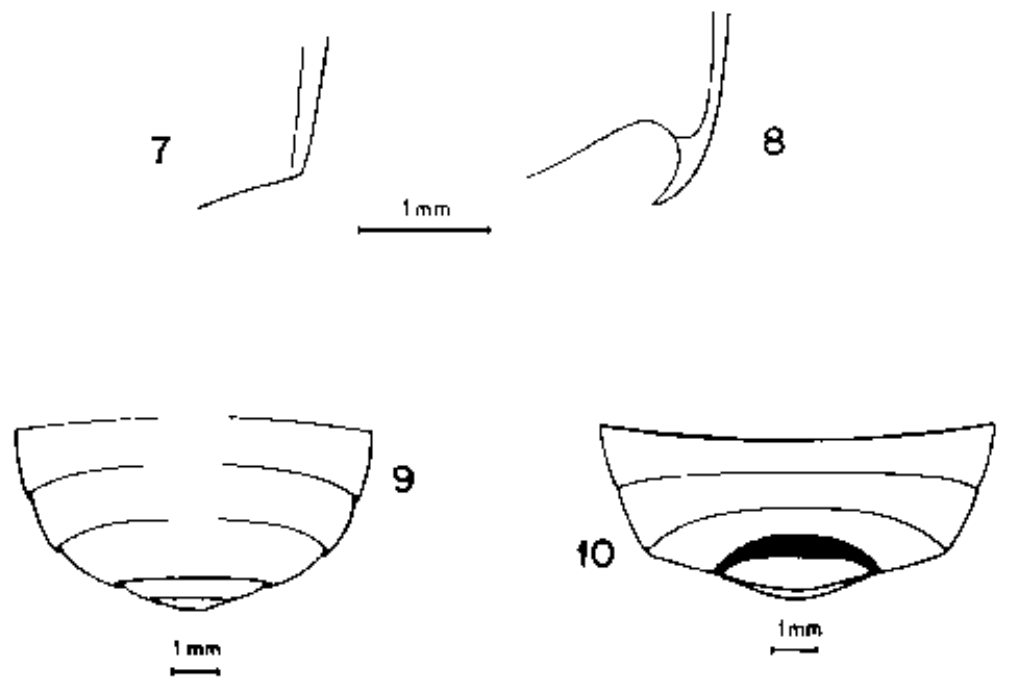

6

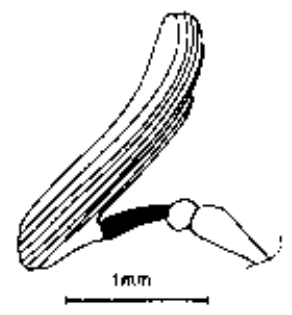

\section{2}

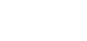

Figs 1-10. Shape of the clypeus of (1) Pachydema anthracina and (2) Ceramida luisae. Antennal club of (3) Hemictenius tekkensis (4) Pachydema anthracina (5) Ceramida luisae, and (6) Leptochristina annamariae. Metacoxae of (7) Hemictenius tekkensis and (8) Elaphocera ibicensis. Abdominal sternites of (9) Melolontha papposa and (10) Pachydema anthracina

Scarabaeoidea, the Melolonthidae present a fore tibia with three teeth on the outer margin and a spine (spur) on the inner margin. The position of the spine relative to the teeth varies among genera within the subfamilies. However, the most frequent condition is a spine behind the second outer tooth (e.g. Pachydema, Melolontha). Character state 1 is only found in the outgroups Euserica and Aplidia, and in the Pachydeminae Ceramida, Europtron, Brenskiella, and Sparrmannia.

\section{Relative length of first hind tarsal joint}

(0) Subequal to or shorter than second joint; (1) Distinctly longer than second joint. In most genera of Pachydeminae and in the outgroups Sericinae and Melolonthinae, the first tarsal joint is shorter or subequal to the second. The derived state, first tarsal joint distinctly longer than the rest, is an autapomorphy of Ceramida.

19 Brush of small yellow setae on the inner surface of pro- and mesotarsal joints

(0) Absent (Fig. 13); (1) Covering only the anterior half of the surface (Fig. 14); (2) Covering the entire surface (Fig. 15). A brush of setae on the pro- and mesotarsal joints seems to be autapomorphic of Pachydeminae. No other subfamily of Melolonthidae presents it. The plesiomorphic condition (brush absent) is found in, for instance, Ceramida, Europtron or Sparrmannia. When the brush is present, it usually covers the 
entire surface of the tarsal joint, as for example in Pachydema or Hemictenius, whereas in Pachydemocera and some species of Elaphocera, the brush covers only the anterior half of the joint. Unordered.

\section{Shape of pro- and mesotarsal joints}

(0) Cylindrical, not enlarged (Figs 13 and 14); (1) Enlarged (Fig. 15). As in the previous character, the enlargement of the tarsal joints seems to be an autapomorphy of Pachydeminae within Melolonthidae. A cylindrical tarsal joint is found in, for instance, Ceramida, Elaphocera, Europtron, Sparrmannia or Phobetus. Most Palearctic genera present the apomorphic condition (enlarged joints) but the degree of enlargement varies greatly among species: in some cases the joint can be as wide as long, or even wider than long, giving the joint the aspect of a spatula.

21 Tarsal claws in males

(0) Basally toothed at the external margin (Fig. 16); (1) Cleft at the apex (Figs 13, 14 and 15); (2) Simple (Fig. 17). In most genera of Pachydeminae and in Euserica the tarsal claws are cleft at the apex. A basally toothed claw is present in Pseudopachydema and the Melolonthinae, whereas Europtron and Brenskiella present simple claws. The tarsal claw of Sparrmannia is both basally toothed and cleft at the apex. Unordered.

\section{Tarsal claws in females}

(0) Basally toothed at the external margin (Fig. 16); (1) Cleft at the apex (Figs 13, 14 and 15). In Euserica female claws are cleft in the apex, whereas they are basally toothed in the Melolonthinae outgroups. In Pachydeminae, it varies considerably, even among species within the same genus (e.g. Tanyproctus reichei: state 1, T. rufidens (Marseul, 1879): state 0) but basally toothed seems to be the most frequent condition.

\section{B Mouthparts}

Mouthparts provide many valuable systematic characters at the generic level in Pachydeminae. Following the degree of mouthpart development, three morphological groups can be distinguished: (a) mouthparts strongly developed; (b) mouthparts slightly developed; and (c) mouthparts very reduced and simple. According to Nel and Scholtz (1990), these groups correspond to different feeding habits: (a) strictly phytophagous on stems and roots; (b) phytophagous on flowers and
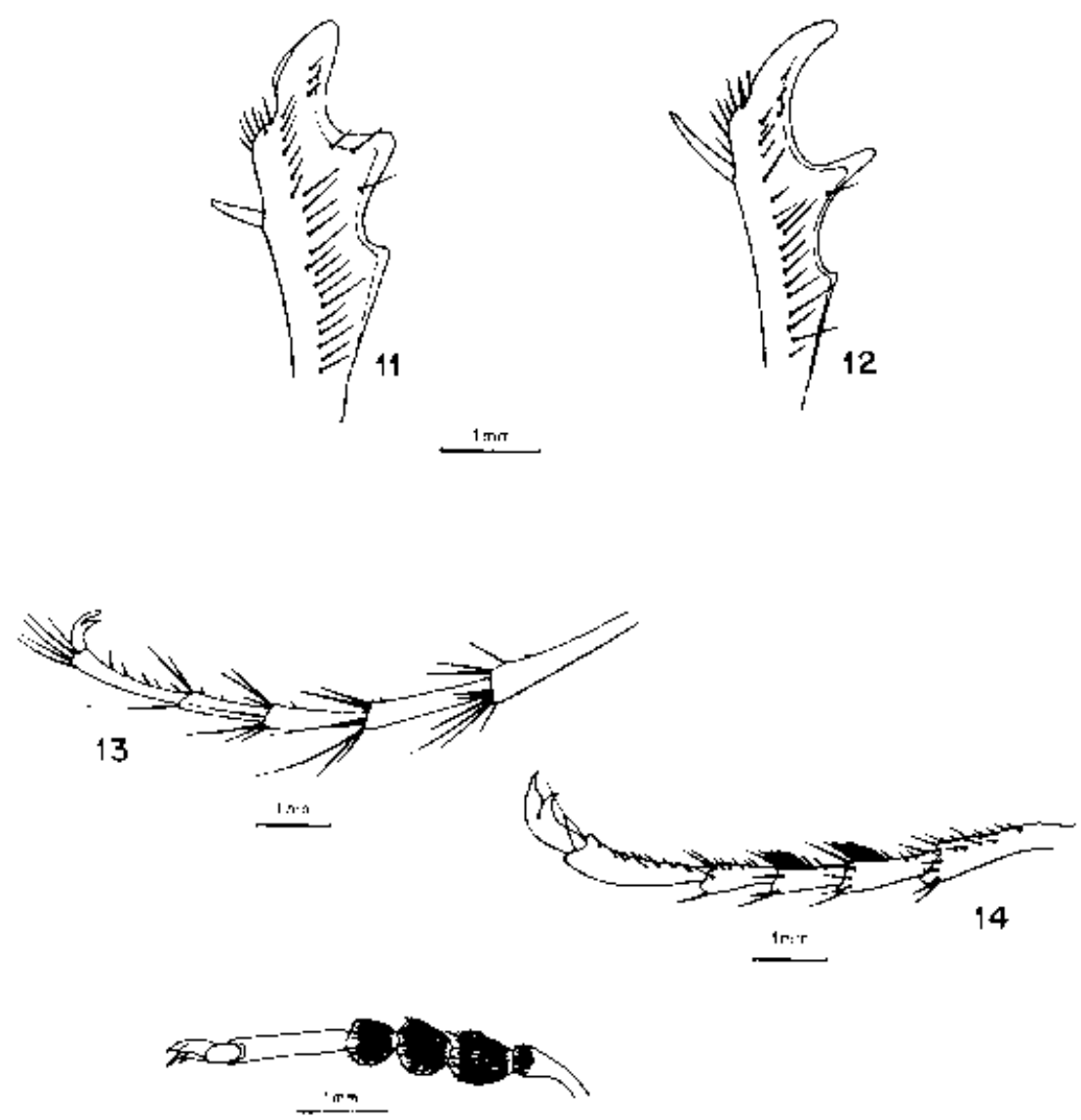

15

Figs 11-17. Fore tibiae of (11) Elaphocera ibicensis and (12) Ceramida cobosi. Male protarsus in lateral view of (13) Ceramida luisae (14) Elaphocera baguenae (15) Pachydema anthracina (ventral view). Female protarsus of (16) Tanyproctus rugulosus, and male protarsus of (17) Europtron gracile (lateral view)
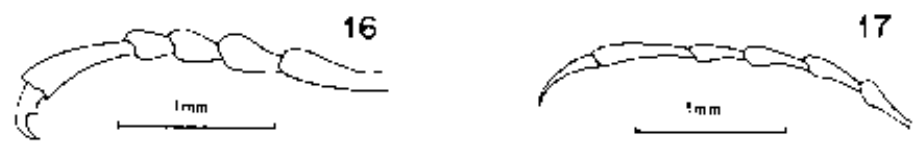
leaves; and (c) nonfeeding adults. Although the biology of Pachydeminae is poorly known, we know that adults of Ceramida do not feed and they present very simple and reduced mouthparts (Sanmartín and Martín-Piera, in prep.).

\section{Anterior margin of labrum}

(0) Strongly mesally sinuated (Fig. 18); (1) Slightly or not sinuated (Figs 19 and 20). A strongly sinuated, almost bilobed labrum is present in Melolonthinae and many genera of Pachydeminae (Hemictenius, Pachydema, Peritryssus, Tanyproctus, Sparrmannia and Phobetus). Some species of Elaphocera also present a sinuated labrum but it is less prominent (e.g. E. capdeboui Schauffus, 1882). Both cases were coded as character state 0 . In the rest of Pachydeminae (e.g. Ceramida, Europtron) and in Euserica, the labrum is only slightly or not sinuated.

\section{Shape of labrum}

(0) Much wider than long, rectangular (Figs 18 and 19); (1) So long as wide, 'tongue'-shaped (Fig. 20). A tongue-shaped labrum, which may be homologous to the intermandibular projection' described in some primitive groups of Scarabaeoidea (Nel and Scholtz 1990), is found in Euserica and some Pachydeminae genera (Ceramida, Otoclinius, Europtron). The rest of Pachydeminae (e.g. Pachydema, Hemictenius, Sparrmannia, Phobetus) and the Melolonthinae present a labrum that is considerably wider than long.

\section{Areas of setae in epipharynx}

(0) All areas present and fully developed (Fig. 21); (1) All areas present but slightly developed (Figs 22 and 23); (2) Most areas reduced, some absent (Fig. 24). Nel and Scholtz (1990) distinguished several areas of setae within the epipharnx of Scarabaeoidea: apical fringe, median brush, lateral combs, lateral tormal processes, antero- and postero-median processes and microsensilla (Fig. 21). The relative development of these areas varies among genera. All outgroup representatives present an epipharynx with fully developed areas. Among the Pachydeminae, this state is found in Hemictenius, Pachydema (except for P. zhora), Peritryssus,

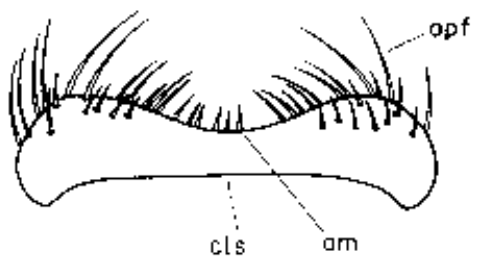

18

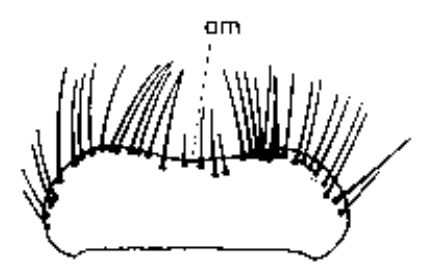

19
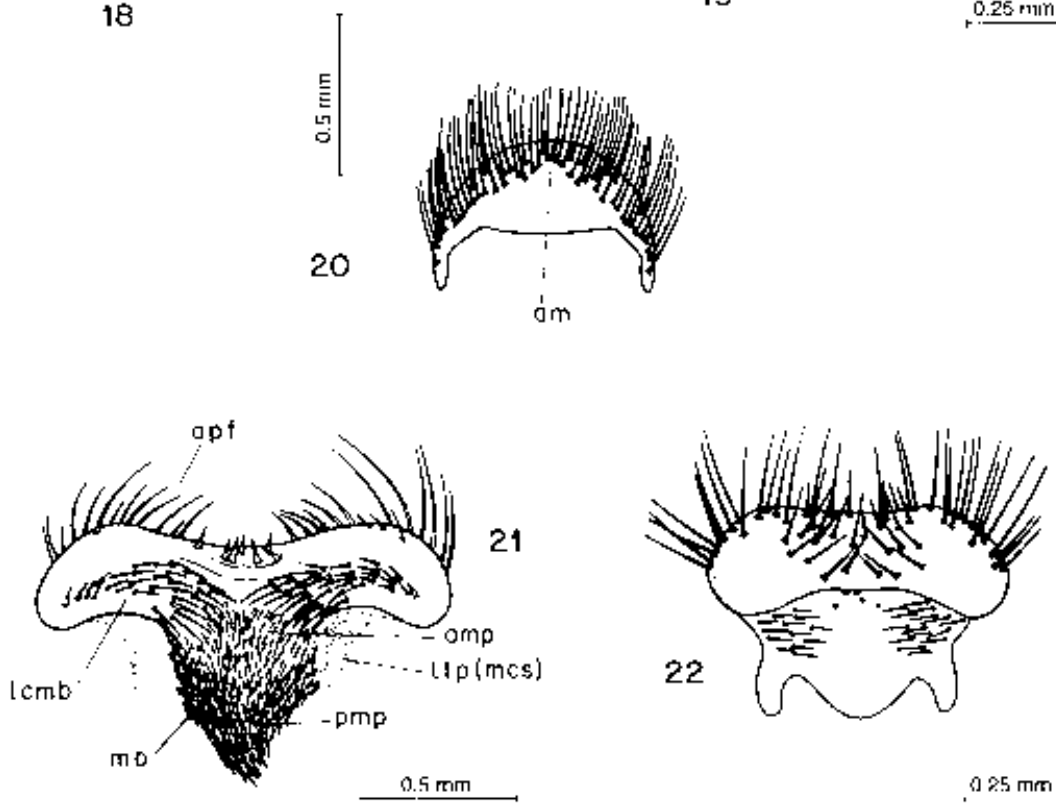

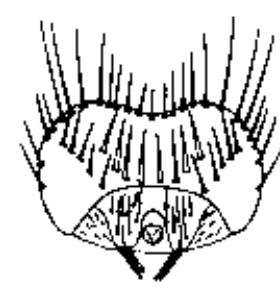

23

, . $0.75 \mathrm{~mm}$

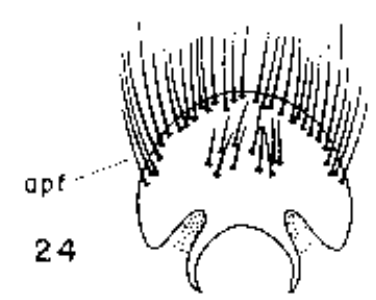

$0.5 \mathrm{mrr}$
Figs 18-24. Labrum of (18) Hemictenius ochripennis (19) Brenskiella flavomicans and (20) Ceramida adusta. Epipharynx of (21) Hemictenius ochripennis (22) Brenskiella flavomicans (23) Pachydemocera lucidicollis and (24) Ceramida adusta. Abbreviations: am: apical margin; amp: antero median processes; apf: apical fringe; cls: clypeo-labral suture; lcmb: lateral combs; ltp: lateral tormal processes; mb: median brush; mcs: microsensillae; pmp: postero median processes 
Phobetus and Sparrmannia. There are two apomorphic conditions, treated as additive. The most frequent is an epipharynx with all areas present but slightly developed, especially the median brush and tormae: Brenskiella, Elaphocera (except E. barbara), Europtron, Leptochristina, Pachydemocera and Tanyproctus (except for $T$. reichei). The alternative condition is an epipharynx with extremely reduced areas, some even absent or inconspicuous (Alaia, Atanyproctus, Ceramida and Otoclinius). This character was coded as ordered because the transition from state $0-2$ presumably went through the morphologically intermediate 1 .

26 Shape of last segment of maxillary palps

(0) Ovate and sharp-pointed (Figs 25, 26 and 27); (1) Elongated and blunt-pointed, 'stick'-like (Fig. 28). The last segment of maxillary palps is typically ovate in Pachydeminae (e.g.
Pachydema), which is the condition present in all outgroup representatives, Melolonthinae and Sericinae. Some species of Pachydema (e.g. P. palposa Reitter, 1902; P. castanea (Brullé, 1838) present extremely enlarged segments, about as wide as the antennal club. The elongated maxillary segment is an autapomorphy of Ceramida.

\section{Ventral region of last segment of maxillary palps}

(0) Distinctly excavated or with a flat area (Fig. 26); (1) Convex, without a distinct area (Fig. 28). In Scarabaeoidea, the last segment of the maxillary palps presents a ventral area covered with sensilla. In the Melolonthinae and in numerous genera of Pachydeminae (Alaia, Brenskiella, Europtron, Hemictenius, Pachydema, Peritryssus, and Sparrmannia), the segment presents a clearly distinctive area, formed by a ridge around a flattened or excavated surface. This excavation is
Figs 25-28. Maxillae of (25) Hemictenius ochripennis (26) Brenskiella flavomicans (27) Pachydemocera lucidicollis and (28) Ceramida adusta. Abbreviations: D (dorsal view): bst: basistipe, cd: cardo, cr: cardoestipital ridge, gl: galea, ls: laterostipes, mxp: maxilar palps, ps: parastipe; $\mathrm{V}$ (ventral view): sp. sensorial peg; ss: sensillum
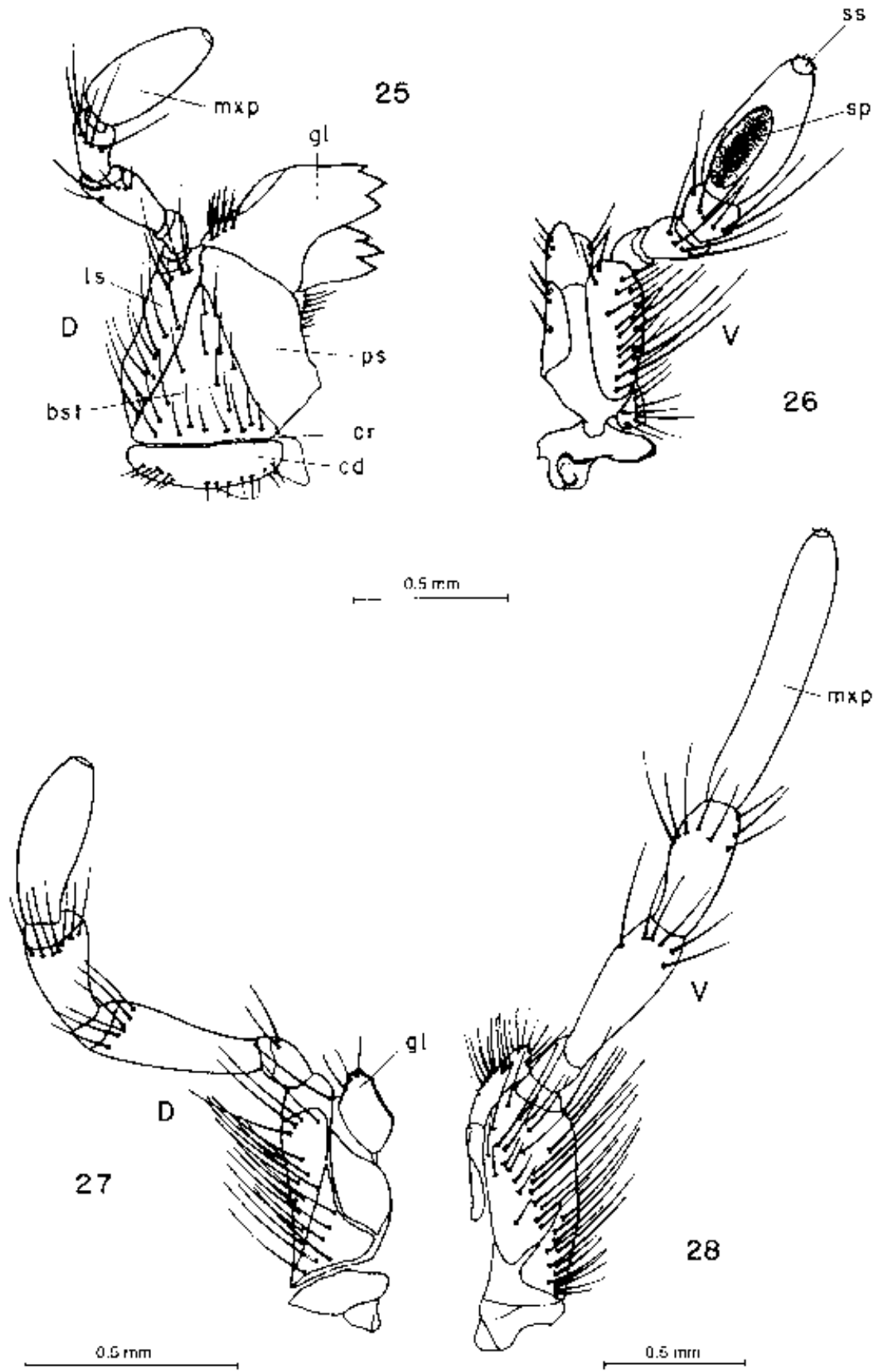
almost a groove bordered by a thick ridge in those species of Pachydema that present very enlarged segments (e.g. P. palposa, P. castanea). The rest of Pachydeminae (e.g. Tanyproctus, Elaphocera, Phobetus) and Euserica present a convex surface, not differing from the rest of the segment except for its dull, unpolished look.

\section{Galea}

(0) Armed with strong teeth or unci (Fig. 25); (1) Massive and spiked (Figs 26 and 27); (2) Unarmed and very reduced (Fig. 28). All outgroup representatives and several genera of Pachydeminae (Hemictenius, Pachydema (except P. zhora),
Peritryssus, Sparrmannia and Phobetus) present a strongly sclerotized, hypertrophied galea, armed with strong teeth or unci. There are two apomorphic states, treated as additive: the most frequent is a massive galea armed with smooth spines (e.g. Elaphocera, Tanyproctus, except T. reichei), whereas a simple, nonarmed galea is found in Ceramida, Europtron, and Otoclinius fragilis Petrovitz, 1980.

29 Mandibles

(0) Hypertrophied (Fig. 29); (1) Normally developed (Fig. 30); (2) Reduced, unarmed, with a blunt scissorial area (Fig. 31); (3) Reduced, unarmed, with a sharp scissorial area (Fig. 32). In
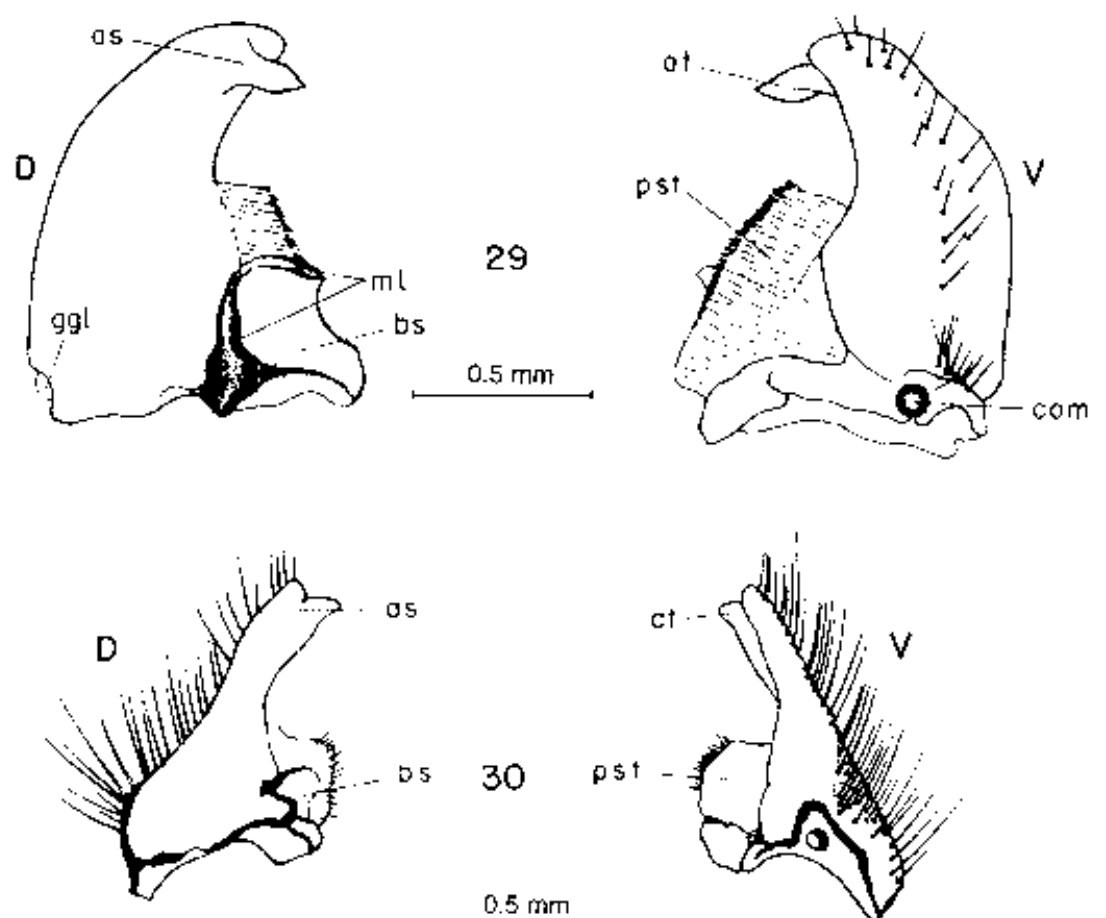

\section{0}
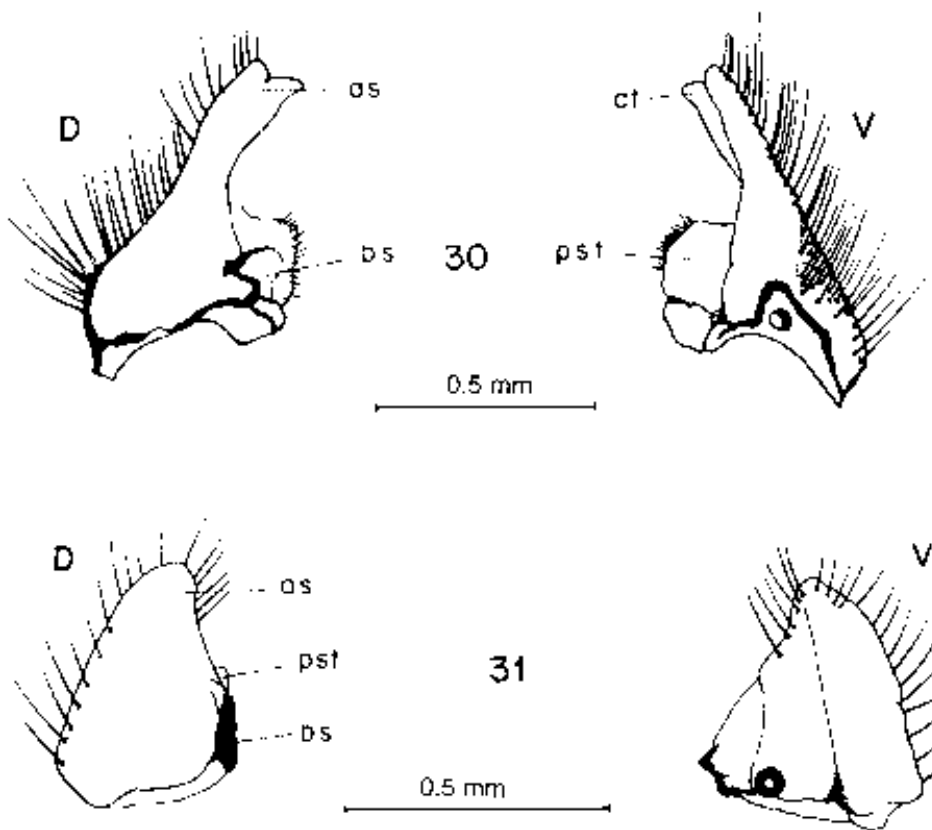

pst

31
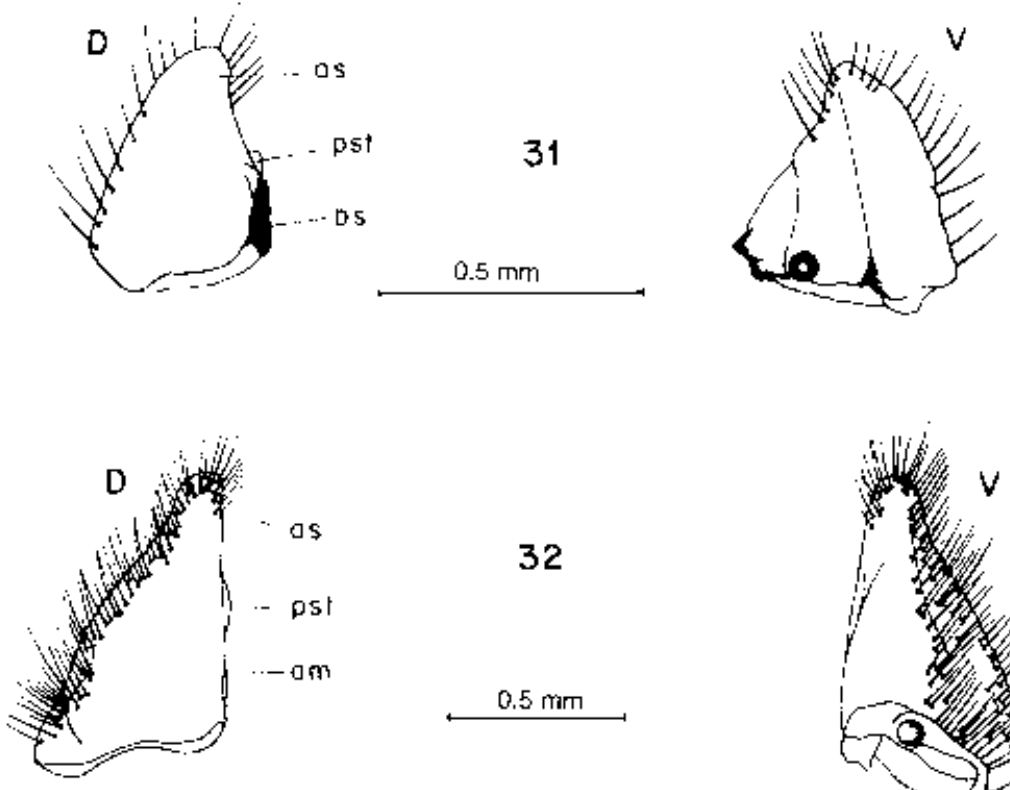

32

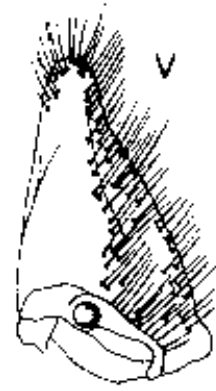

Figs 29-32. Mandibles of (29) Hemictenius ochripennis (30) Brenskiella flavomicans (31) Pachydemocera lucidicollis and (32) Ceramida adusta. Abbreviations: D (dorsal view): as: apicalis (scissorial area), bs: basalis (molar area), ggl: ginglymus, ml: molar lobes; $\mathrm{V}$ (ventral view): at: apical tooth, com: condylus, pst: prostheca 
Melolonthinae and Sericinae and some genera of Pachydeminae (Hemictenius, Pachydema (excepting P. zhora), Peritryssus, Sparrmannia and Phobetus), the mandible is strongly sclerotized, with a large membranous prostheca, toothed molar lobes, and a scissorial area ending in a single or double sharp tooth. There are three apomorphic states. The most frequent (state 1) is a less developed mandible with blunt-toothed molar and scissorial areas and a small prostheca (Atanyproctus, Brenskiella, Elaphocera, Leptochristina and Tanyproctus, except T. reichei). Another type of mandible, probably more derived, corresponds to a reduced, toothless mandible with almost inconspicuous molar area and prostheca. There are two different states within this type of mandible: scissorial area apically blunted (state 2, e.g. Pachydemocera, Otoclinius), and scissorial area apically pointed (state 3, e.g. Ceramida, Europtron). This character was considered unordered because it is not clear whether state 3 evolved from state 2 or both states evolved independently from state 1 .

\section{Shape of labium}

(0) As wide as long, square (Fig. 33); (1) Much longer than wide, rectangular (Fig. 34). The labium of Pachydeminae is typically much longer than wide (e.g. Ceramida, Phobetus, Tanyproctus (except T. reichei), whereas a square labium is present in Hemictenius, Pachydema (except P. zhora), Peritryssus, Sparrmannia and the Melolonthinae.

\section{Wing anatomy}

Kukalova-Peck $(1983,1991)$ established for the first time the homologies of the wing venation and articulation in Pterygota and in Coleoptera (Kukalova-Peck and Lawrence 1993). Following these studies, Browne and Scholtz (1994, 1995) defined the main phylogenetic trends in the evolution of the wing structures in Scarabaeoidea. Hindwing venation and articulation seem to provide good systematic characters for higher level phylogenies in Scarabaeoidea, as they are more conservative (very low phenotypic variability) and less adaptive (stronger genetic control) than mouthparts or genitalia (Browne and Scholtz 1995). However, they are less useful at lower taxonomic levels (genus or species).

Figure 35 shows the groundplan of the hindwing venation in Pachydeminae. In general, most characters present the apomorphic condition within Scarabaeoidea, as defined by Browne and Scholtz (1995). In the radial system, the radial cell is narrow, instead of eyelet-shaped, forming an acute angle with the radial bar. The posterior vein RP is anteriorly incomplete and the first secondary branching has been lost, except for RP2. The medial spur, comprising RP3 +4 and MP1 +2 , reaches the posterior margin of the wing but both branches run in parallel, instead of fused, and the cross-vein $\mathrm{r} 4$ is absent. In the medial system, the secondary branching of MP has been reduced to the MP4 vein, and the anterior cubital vein $\mathrm{CuA}$ is simple, non-branching. In the anal system, AA1 +2 is spike-like and very reduced, whereas $\mathrm{AA} 3+4$ reaches the posterior margin of the wing. AP3 + 4 is the only AP branch present. The jugal veins are lost.

The wing articulation and wing base also present the apomorphic condition with respect to the Scarabaeoidea groundplan (Scholtz et al. 1994). The size of the articulation and base relative to the wing foil is smaller than in more primitive families (Fig. 35). The axillaries of the wing articulation (Figs 36-38) are modified to enhance their articulation with the basivenalia and the wing base (Scholtz et al. 1994). The median plate (MED) and the second basal plate of the wing base show complete fusion of the wing sclerites, while the BMP-BCuA brace is absent (Fig. 35).

Some genera present slight modifications of the hindwing groundplan shown in Fig. 35 that are related to the wing venation:

31 Anterior anal branch AA1 +2 in males

(0) Spike-like (Figs 39 and 40); (1) Reduced to a sinus (Fig. 41); (2) Absent (Fig. 42). All the outgroup representatives and most genera of Pachydeminae present a spike-like anal branch. An anal branch reduced to a sinus (state 1) is an autapomorphy of Peritryssus, whereas the anal branch is missing (state 2) in Pachydema, except for P. zhora and P. rubripennis Lucas, 1848, and Pachydemocera. Ordered assuming the progressive reduction of the anal vein.

\section{Wing anal region in males}

(0) Complete (Figs 39 and 41); (1) Slightly sinuate (Fig. 40); (2) Strongly sinuate, sometimes absent (Fig. 42). Most Pachydeminae (e.g. Hemictenius) present a complete anal region, which is the state found in the outgroups Melolonthinae and Sericinae. There are two derived conditions: slightly sinuated (e.g. Ceramida, Elaphocera, Leptochristina) and strongly sinuated (e.g. Pachydemocera and Pachydema, except P. zhora and $P$. rubripennis). Ordered assuming the progressive reduction of the anal region.
Figs 33, 34. Labium of (33) Hemictenius ochripennis and (34) Brenskiella flavomicans. Abbreviations: lbp: labial palps, mt: mentum, prmt: prementum, sbm: submentum, ss: sensillum

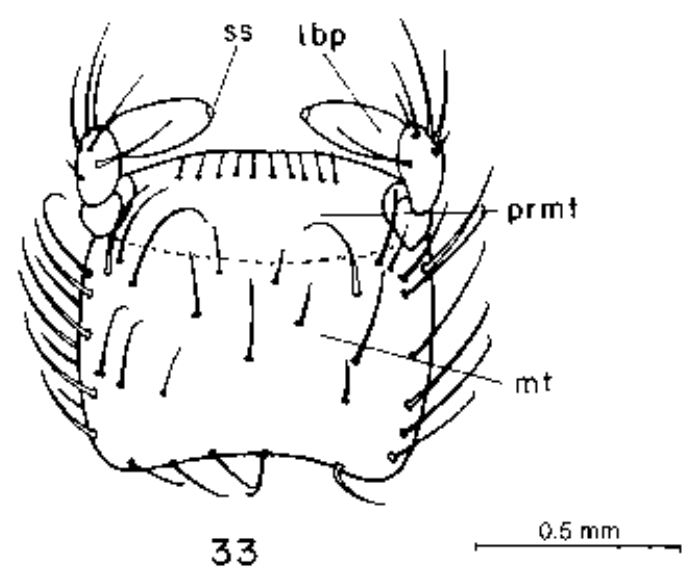

33

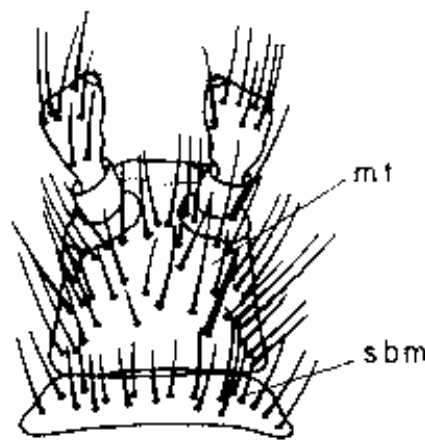

34 


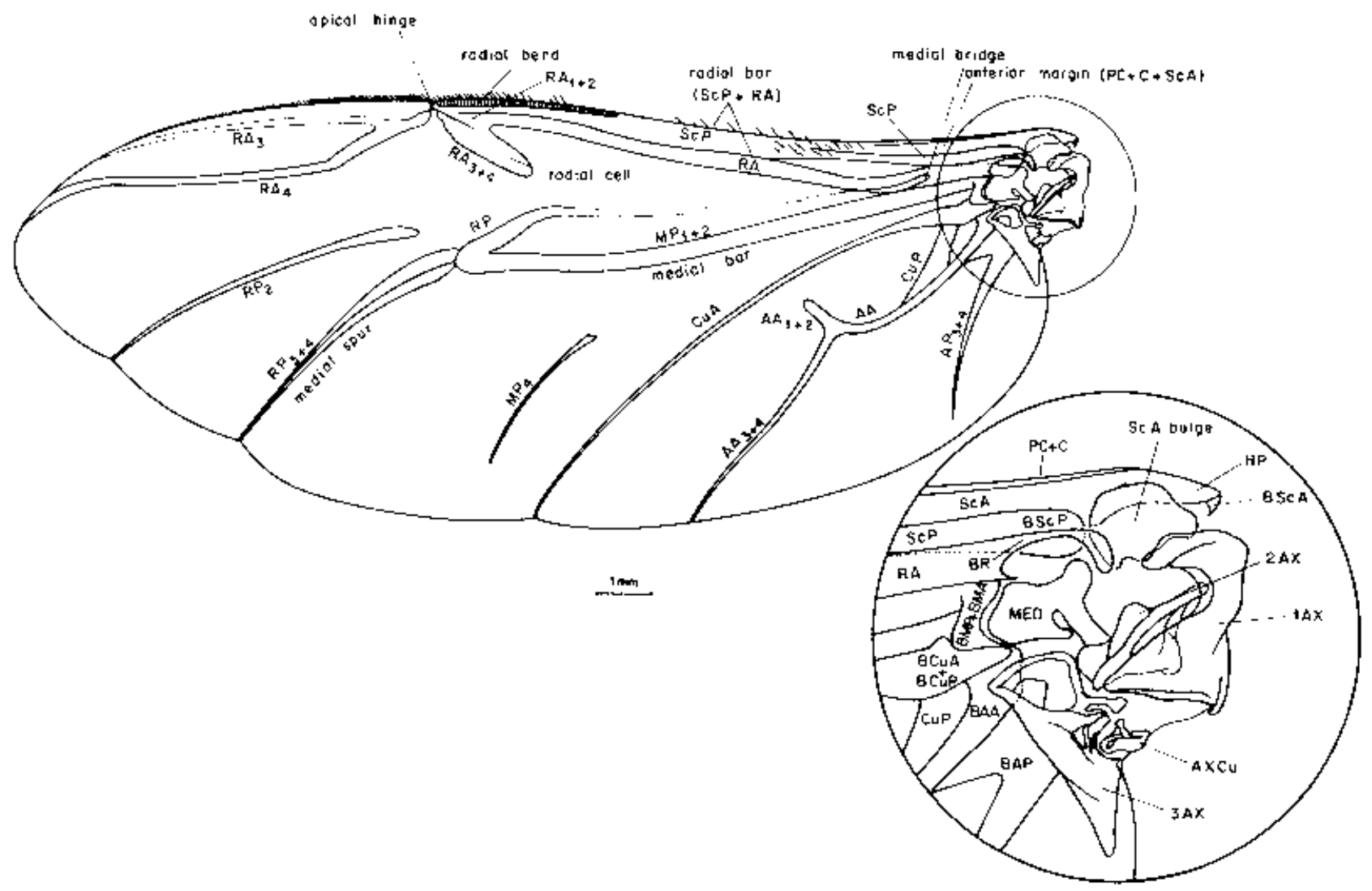

Fig. 35. Scheme of the hindwing of Pachydeminae (Tanyproctus ganglbaueri), showing the groundplan for the wing venation, wing base and wing articulation. Abbreviations of primary veins: AA: Anal anterior; AP: Anal posterior; C: Costa; CuA: Cubitus anterior; CuP: Cubitus posterior; MP: Media posterior; PC: Precosta; RA: Radius anterior; RP: Radius posterior; ScA: Subcosta anterior; ScP: Subcosta posterior. Detail of the wing articulation and wing base: 1AX: First axillary; 2AX: Second axillary; 3AX: Third axillary; AXCu: detached fragment of 3AX derived from the cubital axalar sclerite; BAA: antero-anal basivenale; BAP: postero-anal basivenale; BCuA: antero-cubital basivenale; BCuP: postero-cubital basivenale; BMA: antero-medial basivenale; BMP: postero-medial basivenale; BScA: antero-subcostal basivenale; BScP: postero-subcostal basivenale; BR: radial basivenale. HP: Humeral plate; MED: Median Plate; ScA bulge: prominent bulge in Coleoptera derived from the subcostal anterior brace in ancestral Pterygota

33 Wing state in females

(0) Winged; (1) Brachypterous; (2) Micropterous; (3) Vestigial. Most outgroup representatives present fully winged females. Only Pseudotrematodes present vestigial wings, although the ancestral state in Melolonthinae seems to be winged (CocaAbia 1995). This character varies considerably among the five Palearctic genera of Pachydeminae that could be scored: Pachydema (state 0), Elaphocera (1), Tanyproctus (2), Cerami$d a$ and Hemictenius (3). Ordered following the progressive reduction of the functionality of wings.

\section{Male genitalia}

The male genitalia provide the largest number of systematic characters at the generic and specific levels in Pachydeminae. High specificity of genitalic characters is a common trend in insects (Martín-Piera 1992) and, in general, in animals with internal fertilization (Eberhard 1985). Genitalic specificity has been explained by three different hypotheses. The 'lock-andkey' hypothesis (Dufour 1844; Shapiro and Porter 1989; Mikkola 1992) suggests that genitalic specificity evolved by preinsemination hybridization avoidance, i.e. as a mechanical fit between conspecific male and female genitalia to prevent hybridization. Two other hypotheses, sexual selection by female choice (SSFCh) (Eberhard 1985, 1991; Arnqvist 1998) and the specific mate recognition system (SMRS) (Paterson 1978, 1985; Zunino 1984b, 1987; Zunino and Palestrini 1988; Gwynne 1998) explain male genitalic specificity as a postmating evolutionary mechanism. Genitalic specificity evolved as a mechanism of 'internal courtship', either to stimulate the female to use the male sperm for egg fertilization (SSFCh) or to signal the female that con-specific sperm is being delivered (SMRS).

The male genitalia of Pachydeminae consist of the genital segment, the tegmen, and the internal sac or endophallus. As in most derived groups of Scarabaeoidea (d'Hotman and Scholtz 1990b), the genital segment has been reduced to a spiculum gastrale and the endophallus has taken over the role of the median lobe as the intromittent organ (bilobed aedeagus).

\section{Genital segment}

The genital segment, derived from the IXth abdominal segment, is situated against the ventral wall of the abdominal segments VII and VIII (Krell 1996). Its function is to anchor the aedeagus to the abdominal wall through the third connective membrane and to serve as a connecting base for the genitalic muscles (d'Hotman and Scholtz 1990b). It consists of two structures: the spiculum gastrale, 

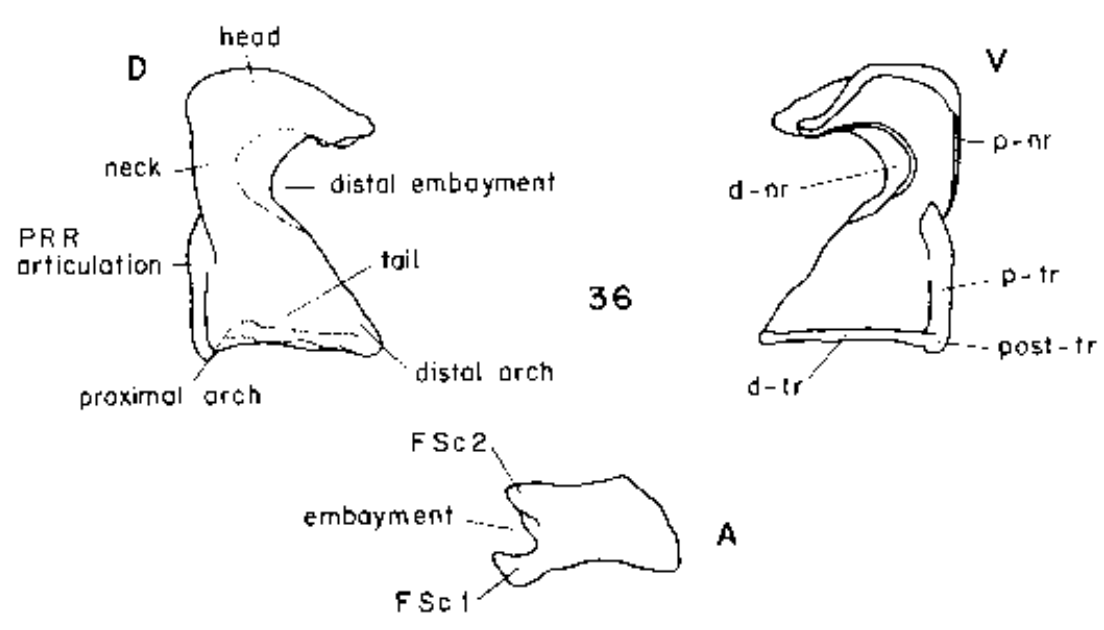

Figs 36-38. Scheme of the axillaries in the wing articulation of Pachydeminae (Tanyproctus ganglbaueri). Abbreviations: (36) First axillary ( $1 \mathrm{AX})$ in dorsal (D), ventral $(\mathrm{V})$, and anterior view (A), showing d-nr: distal neck ridge, d-tr: distal tail ridge, FSc: ventral (FSc1) and dorsal (FSc2) teeth of the $1 \mathrm{AX}$ head, composed of the subcostal fulcalare, p-nr: proximal neck ridge, $p$-tr: proximal tail ridge, post-tr: posterior tail ridge. (37) Second axillary $(2 \mathrm{Ax})$ in dorsal (D) and ventral (V) view, showing: d-dl: dorso-distal lobe, d-dr: dorso-distal ridge, d-pl: dorso-proximal lobe, d-pr: dorsoproximal ridge, PWP: posterior wing proccess junction, STAP: subalare tendon attachment point, v-dl: ventro-distal lobe, $\mathrm{v}$-dr: ventro-distal ridge, v-pl: ventro-proximal lobe, v-pr: ventro-proximal ridge. (38) Third axillary (3AX) in dorsal (D) and ventral (V) view: AXA: anal axalare, AXCu: cubital axalare, AXJ: jugal axalare, FA: anal fulcalare, $\mathrm{FCu}$ : cubital fulcalare, FJ: jugal fulcalare
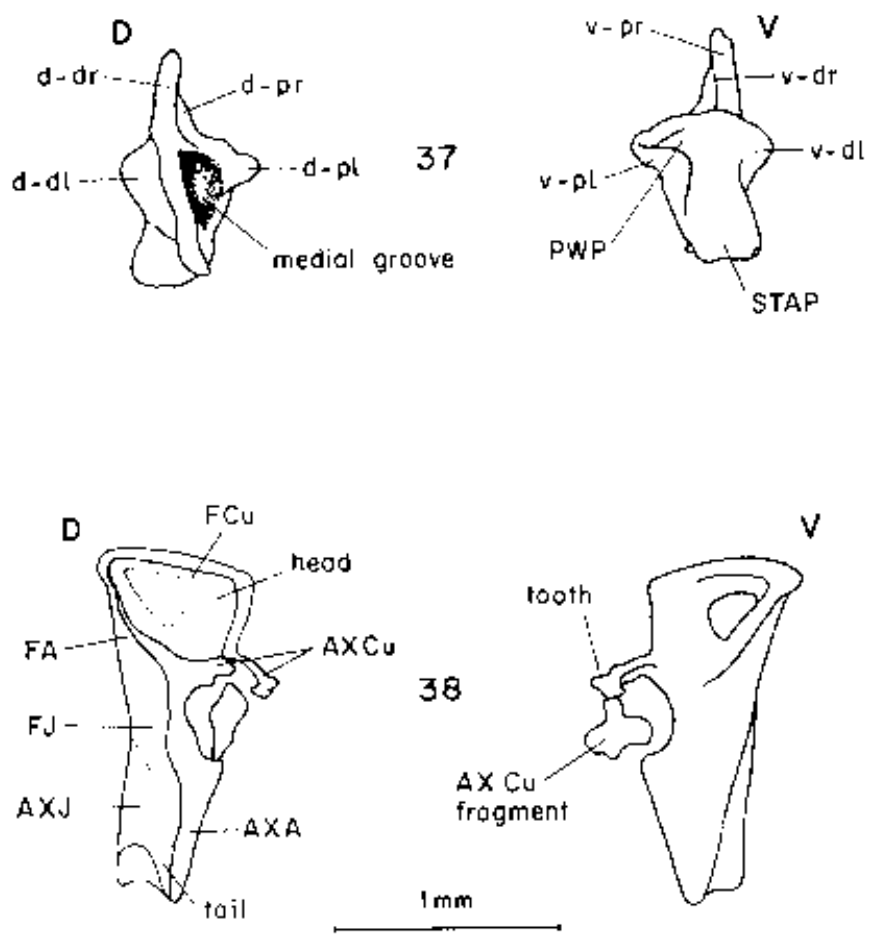

a $\mathrm{Y} / \mathrm{U}$-shaped sclerite homologous with the dorsal plate of the primitive genital capsule, and the vestigial sternite, a small sclerite derived form the ventral plate (Hieke 1966). Both structures show modifications at the generic level:

34 Shape of the spiculum gastrale

(0) 'Y'-shaped with a fine long vertical branch (Fig. 43); (1) 'U'-shaped, with a short vertical branch (Figs 44 and 45); (2) ' $Y$ '-shaped with a robust long vertical branch (Figs 46 and 47); (3) Square. An 'Y'-shaped spiculum gastrale (state 0) is found in the outgroups Melolonthinae and Sericinae, and in Sparrmannia, whereas the 'square' spiculum (state 3) is an autapomorphy of Phobetus. The ' $\mathrm{Y}$ '-shaped spiculum of Ceramida and Peritryssus (state 2) differs from that of the outgroup in presenting a robust vertical branch with lateral sclerites. The 'U'-shaped spiculum (state 1) is the most often found in the Palearctic Pachydeminae (e.g. Elaphocera, Pachydema). Unordered.
35 Development of the vestigial sternite

(0) Reduced (Fig. 46); (1) Partially developed (Fig. 45); (2) Completely developed (Fig. 44). The reduced sternite is only found in Ceramida and the outgroups Euserica, Pseudotrematodes and Aplidia. In Ceramida, however, the sternite is reduced to a small pair of lateral sclerites, whereas Pseudotrematodes and Aplidia present a small piece at the base of the vertical branch. In most Pachydeminae genera and the outgroups Melolontha and Polyphylla, the vestigial sternite is completely developed, whereas it is partially developed in Elaphocera and Pachydemocera. This character was scored as ordered because state 1 is morphologically intermediate between 0 and 2 .

\section{Tegmen}

The tegmen is derived from the $\mathrm{X}$ abdominal segment (Krell 1996). It consists of a proximal basal piece, the phallobase, and two paired distal sclerites anchored to the apex of the 

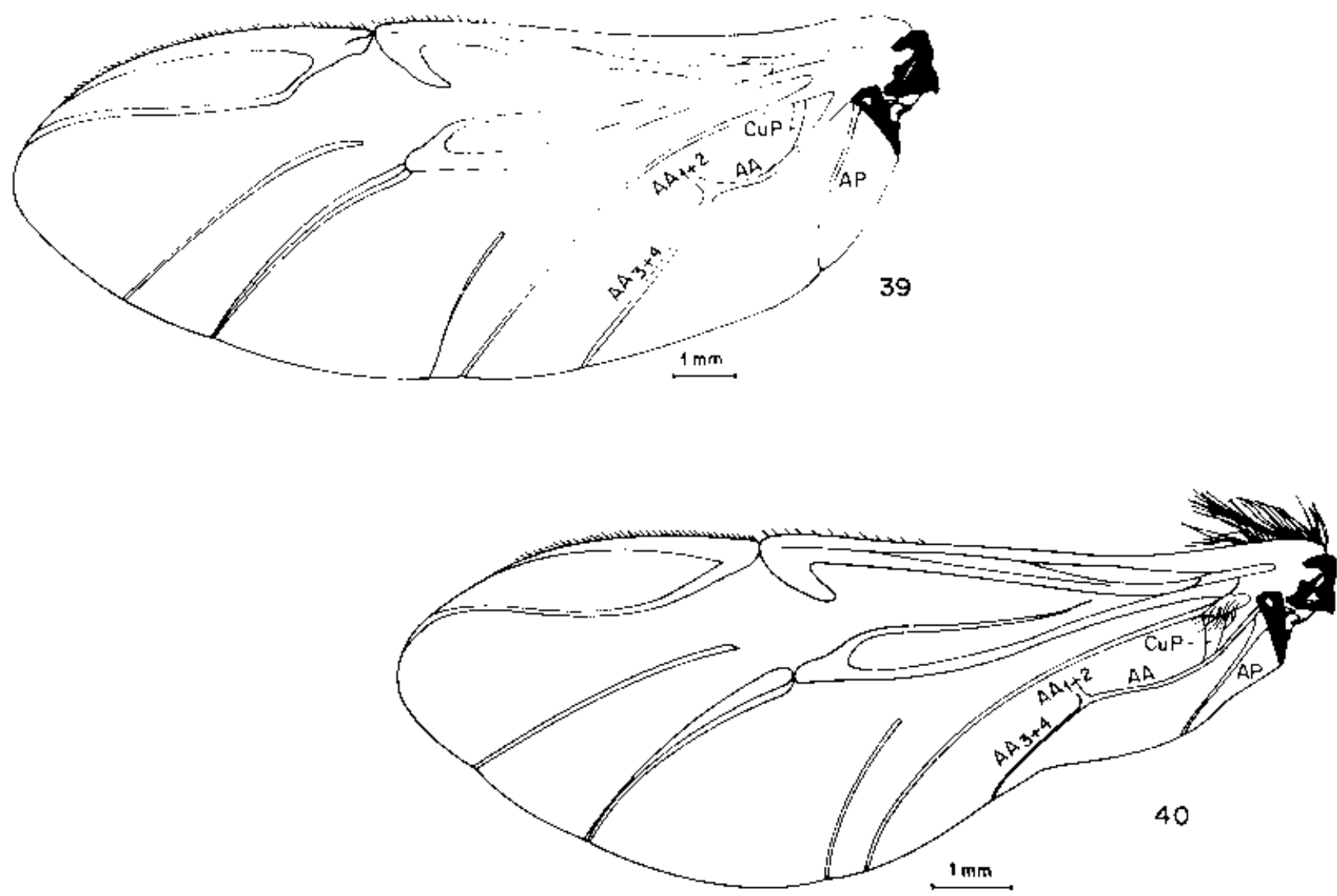

Figs 39, 40. Modifications in the hind wing venation of Pachydeminae: (39) Tanyproctus ganglbaueri; (40) Elaphocera alonsoi. Abbreviations as in Fig. 35

phallobase, the parameres (Fig. 48). In Pachydeminae, the phallobase and parameres are ventrally desclerotized, which is the derived state within Scarabaeoidea (d'Hotman and Scholtz 1990b). The apex of parameres presents setae of variable morphology (Fig. 49), presumably of sensorial function. The relative size of phallobase and parameres, as well as their shape and sculpture, provide numerous characters at the generic and specific levels in Pachydeminae:

\section{Ratio Parameres/Phallobase $(P / F)$}

(0) $\mathrm{P} / \mathrm{F} \geq 1$ (Figs 50 and 51); (1)(P)/F $<1$ (Fig. 52). The most widespread condition in Pachydeminae and the outgroups is parameres larger or equal to the phallobase (state 0 ), whereas parameres shorter than phallobase is found in Euserica, Pseudotrematodes, Sparrmannia, Phobetus, Pachydemocera, Kryzhanovskia, Elaphocera (except for E. barbara and E. syriaca Kraatz, 1882), and Ceramida baraudi Branco, 1981.

\section{Dorsal strangulation of phallobase}

(0) Weak (Fig. 52); (1) Strong (Figs 53 and 54); (2) Absent. The dorsal strangulation of the phallobase (Fig. 48) serves as attachment point for the second connective membrane (Krell 1996). A strong, almost channel-like strangulation is found in most Palearctic genera of Pachydeminae (e.g. Pachydema) and in Euserica. On the other hand, this strangulation is very weak in Sparrmannia, Ceramida, some species of Elaphocera (E. syriaca, E. barbara), and the Melolonthinae, and it is missing in Phobetus.
38 Basal ostium of phallobase

(0) Symmetrical (Figs 50, 51 and 53); (1) Asymmetrical (Figs 52 and 54). In Melolonthidae, the ventral side of the phallobase is partly obliterated by the second connective membrane, delimiting a basal opening (basal ostium). The ostium is usually larger in the Pachydeminae than in Melolonthinae (Fig. 48). In some genera of Pachydeminae, such as Atanyproctus, Pachydemocera, Peritryssus, Phobetus, Elaphocera and Ceramida, one side of the basal ostium is more basally developed than the other, giving the phallobase an asymmetrical look in lateral view (Fig. 54). All other genera of Pachydeminae and the outgroup representatives present the plesiomorphic condition, a symmetric basal ostium.

\section{Degree of sclerotization of parameres}

(0) Evenly sclerotized and continuous; (1) Ventrally desclerotized and membranous, not continuous. The primitive condition in Scarabaeoidea is evenly, well sclerotized parameres (d'Hotman and Scholtz 1990a), which is also the condition in the outgroups Melolonthinae and Sericinae. The Pachydeminae present the apomorphic condition: paramereres ventrally membranous and only partially sclerotized on the dorsal side (Fig. 48). This character has been used to distinguish Pachydeminae from Melolonthinae and Sericinae (Baraud 1992). Another difference between the three subfamilies is that the parameres of Pachydeminae are symmetrical, whereas they are asymmetrical in Sericinae and can be strongly asymmetrical in Melolonthinae (Coca-Abia 1995), such as in Aplidia and Pseudotrematodes. 

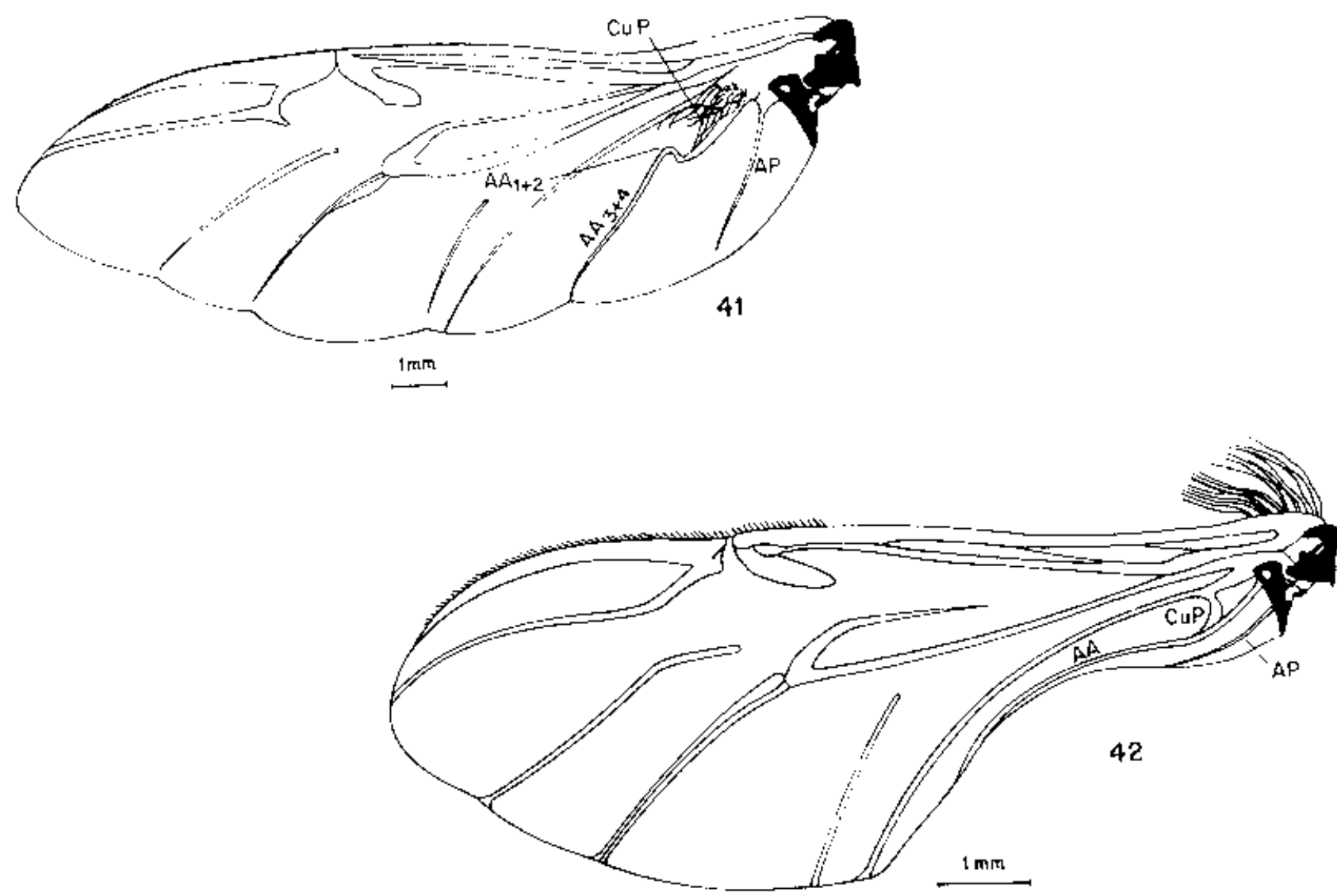

Figs 41, 42. Modifications in the hind wing venation of Pachydeminae; (41) Peritryssuss excisus; (42) Pachydemocera lucidicollis. Abbreviations as in Fig. 35

\section{Lateral face of parameres}

(0) Convex (Figs 50, 51, 52 and 54); (1) Compressed (Fig. 53). The apomorphic state, laterally compressed, 'duck bill'-like parameres (Fig. 53), are only found in Brenskiella, Europtron, and Sparrmannia. In all other Pachydeminae and the outgroups, the parameres are convex.

\section{Profile of parameres}

(0) Straight; (1) Curved throughout (Fig. 51) or with two different parts: the distal curved or straight (Fig. 50); (2) Distally curved, sickle-shaped (Fig. 54); (3) Elbowed near the middle, defining a broken line (Fig. 52). This character could not be scored for the outgroups due to difficulties with assessing homology (character inapplicable). Among the Pachydeminae, the character varies considerably. It is, for example, straight in Leptochristina (0), curved throughout in Hemictenius (1), sickle-shaped in Elaphocera (2), except for E. barbara, and elbowed near the middle in Ceramida (3). Unordered.

\section{Apex of parameres (lateral view)}

(0) Sharp (Fig. 51); (1) Apically scooped-out or with a terminal sinus (Fig. 50); (2) Blunt (Fig. 52); (3) Bent apex with clasps. This character is very variable among the outgroups: sharp (0) in Pseudotrematodes and Aplidia, scooped-out (1) in Melolontha and Polyphylla. State 3 is an autapomorphy of Euserica. It also varies greatly among the Pachydeminae. The blunt apex is the most widespread condition, being present in numerous genera (e.g. Ceramida,
Elaphocera, Leptochristina, Pachydemocera), as well as in Pachydema zhora and Atanyproctus miksici Petrovitz, 1965. A sharp apex is found in Hemictenius, Peritryssus, Sparrmannia, and some species of Pachydema (e.g. P. anthracina Fairmaire, 1860, P. castanea, P. bipartita (Brullé, 1838)). The apically scooped-out apex occurs in Tanyproctus (except $T$. saulcyi (Reiche, 1856)), most species of Pachydema (e.g. P. rubripennis), Atanyproctus simplicitarsis Petrovitz, 1954, and in Phobetus. The character therefore varies at the species level in Pachydema and Atanyproctus. Unordered.

\section{Apex of parameres (dorsal view)}

(0) Without lateral processes or lateral expanded ends (Figs 51, 52 and 53); (1) With lateral processes (Figs 50 and 54). As above, this character varies among the outgroups, although the ancestral state of Melolonthinae (and the one most often found here) is probably 0 (Coca-Abia 1995). Euserica has very complex processes, in the form of claspdevices. Most species of Pachydeminae present parameres with lateral processes but the shape of these processes varies greatly among genera and even among species within genera. For example, depending of the species, the lateral processes of Pachydema or Tanyproctus can be rounded, hook-like, arrowshaped, spear-shaped, etc.

\section{Endophallus (Fig. 55)}

The endophallus provides the largest number of taxonomic characters at the generic, specific and species-group level. At rest, the endophallus lies within the phallobase, anchored to 

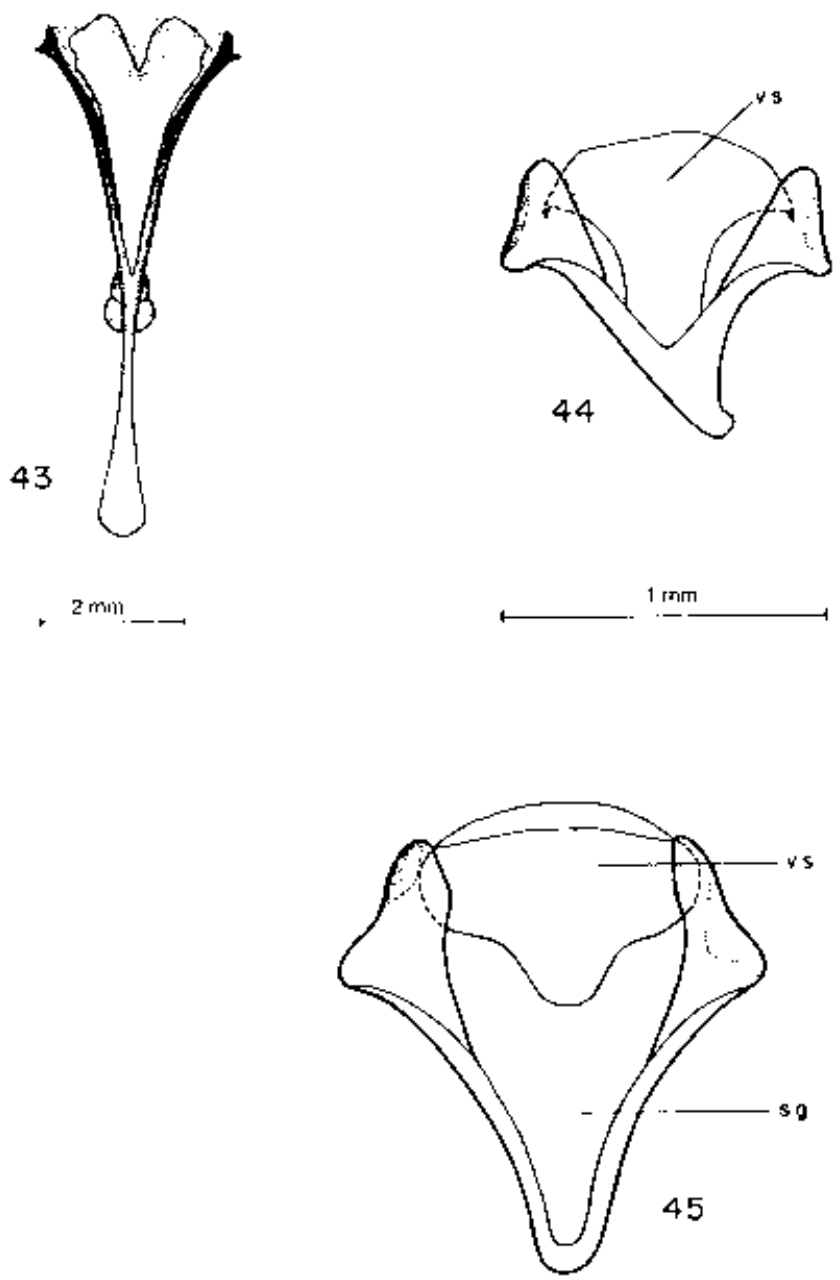

Figs 43-45. Genital segment of (43) Polyphylla fullo (from Coca-Abia 1995) (44) Pachydema anthracina and (45) Elaphocera martorelli. Abbreviations: sg: spiculum gastrale, vs: vestigial sternite

the tegmen through the first connective membrane. During copulation the endophallus evaginates through the apical ostium delimited by the paramere apices (Fig. 48). The endophallus of Pachydeminae presents two sclerotized structures: the temones and the 'V-shaped piece'. These structures probably serve as mechanical reinforcements during the evagination, or as attachment points for the intra-aedeagal muscles during copulation (d'Hotman and Scholtz 1990b; Krell 1996). The temones (d'Hotman and Scholtz 1990b) are paired elongate apophyses, articulating to the base of endophallus in dorsal position and extending downwards into the basal piece (d'Hotman and Scholtz 1990b). The V-shaped piece is a sclerotized sclerite, situated ventrally at the base of the endophallus and often divided into two pieces (Fig. 55). These structures are presumably derived from the median lobe (Zunino and Monteresino 1990; Krell 1996). This is supported by the fact that the first connective membrane of Pachydeminae is attached to the $\mathrm{V}$-shaped piece, instead of to the median lobe. Figure 56 shows the first photographs of spermatozoids in Pachydeminae.

44 Anatomy of endophallus

(0) With a caudal diverticle (Fig. 57); (1) Simple (Fig. 58); (2) With a secondary sac attached to temones (Fig. 59). The
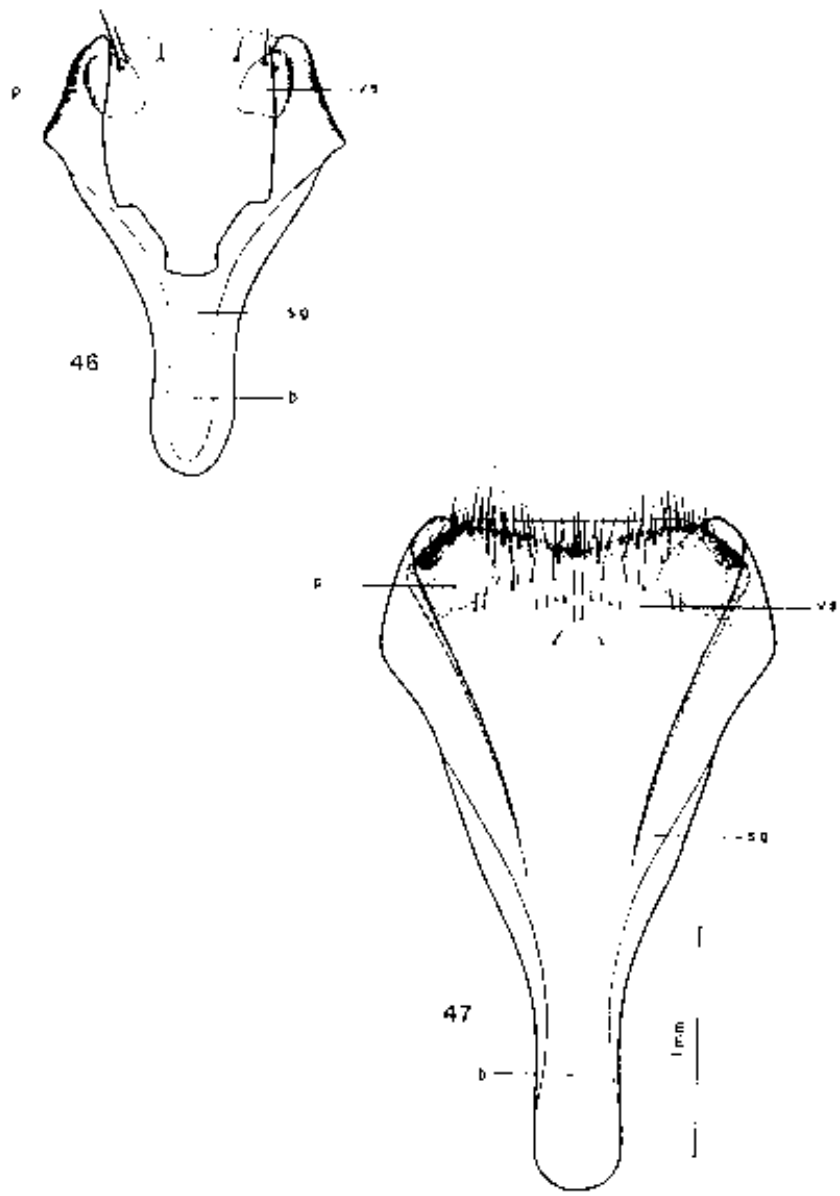

Figs 46, 47. Genital segment of (46) Ceramida cobosi and (47) Peritryssus excisus. Abbreviations: b: vertical branch of the spiculum gastrale, p: lateral sclerites, sg: spiculum gastrale, vs: vestigial sternite

endophallus of the outgroups Melolontha and Pseudotrematodes, Sparrmannia, Phobetus, and most Palearctic genera of Pachydeminae presents a caudal diverticle (Hemictenius, Fig. 57; Pachydema, Fig. 60; Tanyproctus, Fig. 61; Tanyproctoides, Fig. 62; Otoclinius, Fig. 63; Atanyproctus, Fig. 64). A simple endophallus is present in Ceramida (Fig. 58), Leptochristina (Fig. 65), and the outgroups Euserica, Polyphylla and Aplidia. The endophallus of Elaphocera and Pachydemocera (Fig. 59) presents a membranous sac of unknown function, extending from the base to the apex of the temones. Unordered.

45 Sclerotized structures in the endophallus

(0) Present (Fig. 57 sp.); (1) Absent (Fig. 58). Presence of sclerotized structures in the endophallus seems to be the primitive condition in Scarabaeoidea (d'Hotman and Scholtz 1990 b) but this character varies in Pachydeminae and the outgroups (the most frequent condition is presence of sclerotizations). When it is present, the internal sac armature is a useful taxonomic character at the species level. Some species of Pachydema (e.g. P. hirticollis (Fabricius, 1787)), Fig. 55 sh, $56(f)$ present 'hook'-like structures, whereas sclerotized plates of different morphology have been found in Hemictenius (Fig. 57 sp.), Tanyproctus reichei (Fig. 61 th) and other species 
Fig. 48. Tegmen of Pachydeminae (Pachydema anthracina) in lateral (L), dorsal (D) and ventral (V) view. Abbreviations: a: apex of parameres, ao: apical ostium, bo: basal ostium, cm: connective membrane, $\mathrm{dm}$ : dorsal membrane of parameres, ds: dorsal strangulation of phallobase, $\mathrm{Ph}$ : phallobase, Pm: parameres, scm: second connective membrane, vm: ventral membrane of parameres. The dorsal and ventral orientation of the aedeagus were determined according to the criterion of Zunino and Monteresino (1990) and Coca-Abia and Martín-Piera (1991), opposite to that of d'Hotman and Scholtz (1990b)
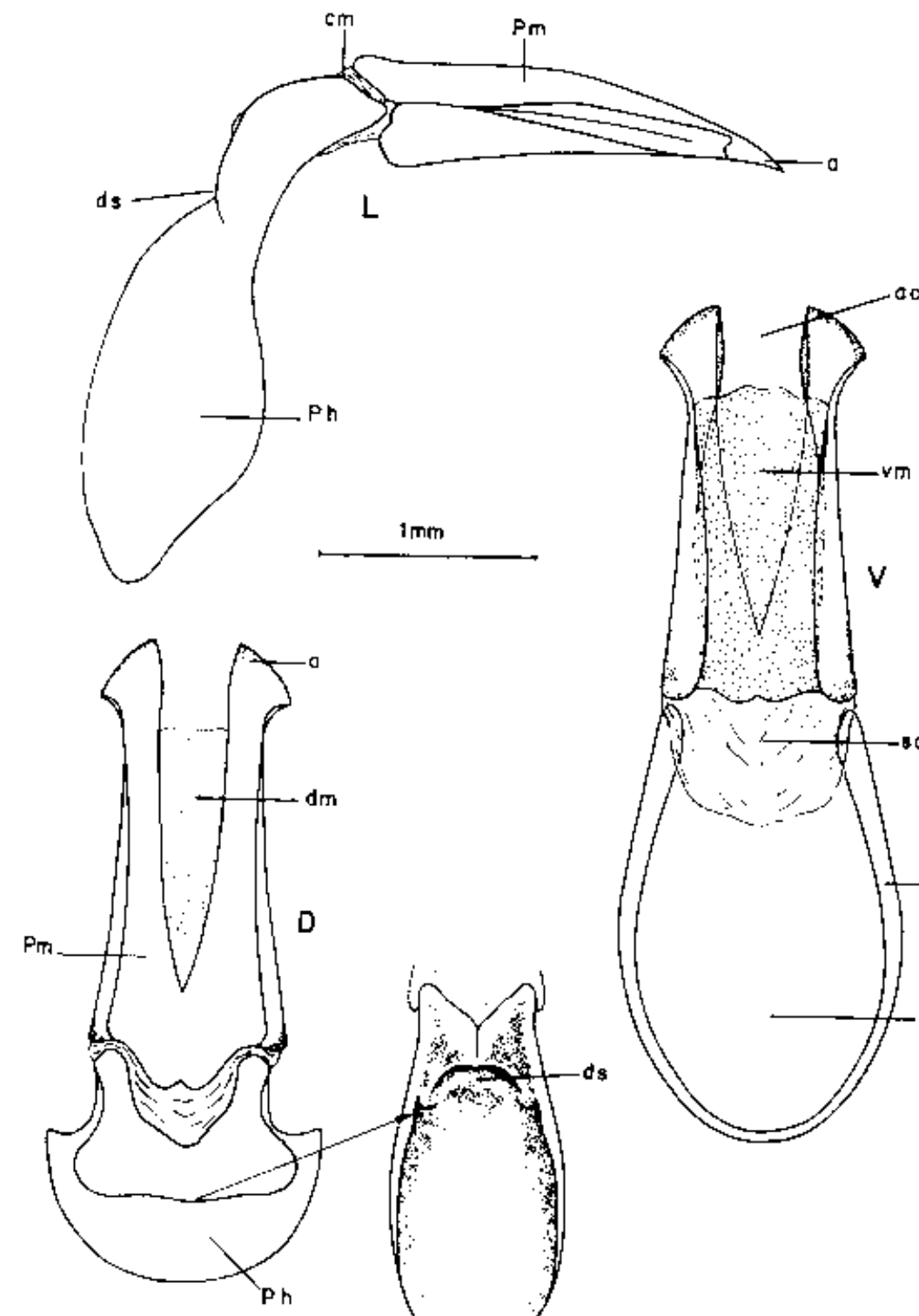

$\checkmark$ of Pachydema (P. menieri Baraud, 1985; Fig. 60 sp.). The hook-like structures might function as a mechanism to anchor the endophallus within the female's reproductive system during copulation, i.e. a 'clasping device' (d'Hotman and Scholtz 1990b). The function of the sclerotized plates is not so clear but since they usually present spines or teeth on their surface (Fig. 56h), these plates could help to stimulate the female during copulation in a sort of 'internal courtship' (Eberhard 1985; Zunino 1987). These sclerotized structures are usually surrounded by a highly dense sensilliferous area (Figs $55 r$ and 56g), termed 'raspula' (Coca-Abia and Martín-Piera 1991).

\section{Position of the V-shaped piece relative to temones}

(0) Reaching temones (Fig. 57); (1) Not reaching temones (Fig. 58). This character could not be scored for Aplidia and Euserica. Aplidia presents a median lobe instead of temones, and Euserica lacks the V-shaped piece. The V-shaped piece of most Pachydeminae and the outgroups reaches the temones without being fused to them, whereas in Ceramida (Fig. 58),
Pseudotrematodes, Sparrmannia and Phobetus a membranous area separates the $\mathrm{V}$-shaped piece from the apex of temones.

47 Length of $V$-shaped piece relative to length of temones (0) $\mathrm{Pv} / \mathrm{T}=1 / 3 \quad$ (Fig. 57); (1) $\mathrm{Pv} / \mathrm{T}=1 / 2 ;$ (2) $\mathrm{Pv} / \mathrm{T}=1 / 1$ (Fig. 59). This character could not be scored for Aplidia and Euserica (see above), varying among the other outgroups: (0) Pseudotrematodes, (2) Melolontha, Polyphylla. In Pachydeminae, the V-shaped piece is typically one-third of the length of temones (e.g. Pachydema, Phobetus) but in Pachydemocera and some species of Elaphocera (e.g. E. elongata Schauffus, 1874), the $\mathrm{V}$-shaped piece is the same length as temones. In that case, $\mathrm{V}$-shaped piece and temones are fused forming a continuous sclerotized ring that might serve to reinforce the opening through which the endophallus is evaginated (Fig. 59). In other species of Elaphocera (e.g. E. emarginata (Gyllenhal, 1817), E. syriaca) and Sparrmannia, the V-shaped piece is onehalf the length of temones, whereas in E. barbara, it is one third of the length of temones. Ordered assuming state 1 is morphologically intermediate between state 0 and state 2 . 

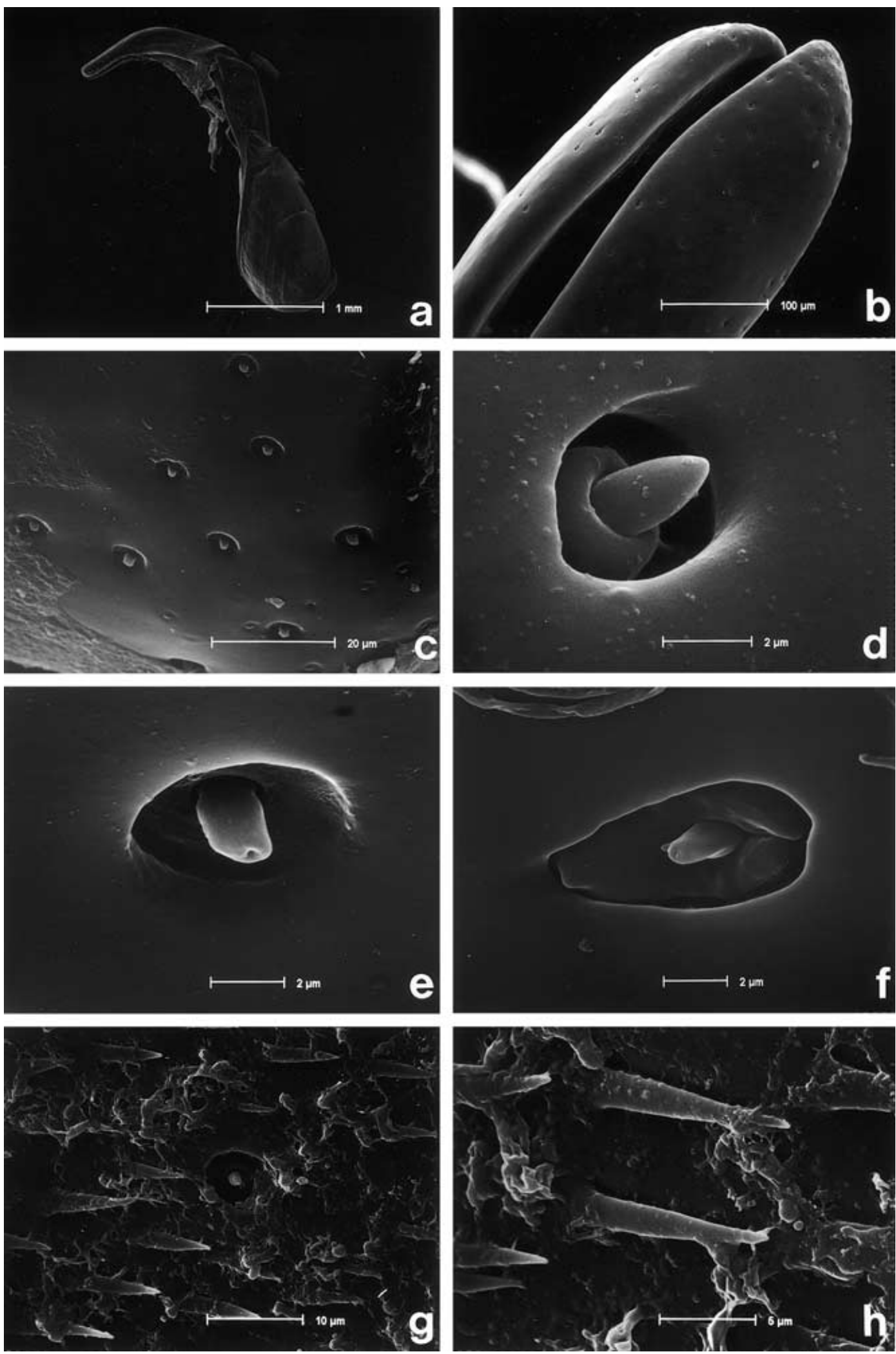

Fig. 49. Scanning electron micrograph of the tegmen of Elaphocera alonsoi (a-f) and Tanyproctus $(\mathrm{g}-\mathrm{h})$, showing sensorial setae of different morphology in the apices of parameres

48 Areas of sensory setae or sensillae in the endophallus

(0) With only a medial area (Fig. 58); (1) With medial and distal areas (Fig. 61); (2) With basal, medial, and distal areas (Fig. 57); (3) With medial and basal areas (Fig. 66). The endophallus of Scarabaeoidea is usually externally lined with fine, presumably sensory setae or sensilla (d'Hotman and Scholtz 1990b). In Pachydeminae, the morphology and disposition of these sensilla are highly specific (Fig. 67). Starting 

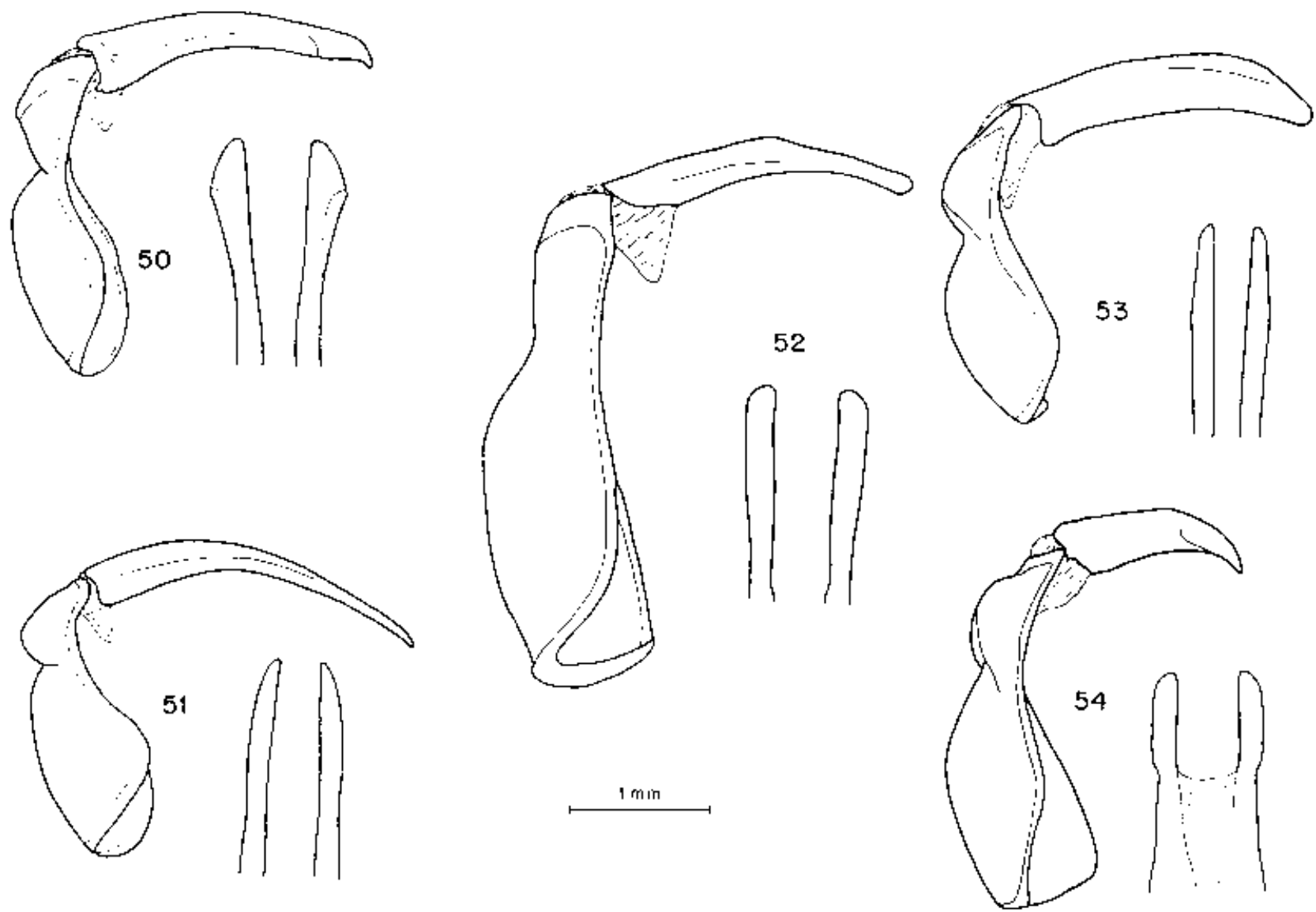

Figs 50-54. Lateral view of the tegmen and dorsal view of the parameres of (50) Pachydema fuscipennis (51) Hemictenius gracilipes (52) Ceramida bedeaui (53) Europtron gracile and (54) Elaphocera ibicensis

from the caudal to the cephalic region of the endophallus, three different areas, each one characterized by a particular type(s) of sensilla, can be distinguished: a distal area (I), a medial area (II), and a basal area (III) (Fig. 55). According to the theories of Eberhard (1985) and Zunino (1987), the highly specific sensilla of the endophallus could be used by the male to stimulate the female during a postmating 'internal courtship'. The character varies considerably among Pachydeminae and the outgroups (no setae were observed in the endophallus of Euserica), although the most common state seems to be 0 . For example, a medial area is present in Ceramida (Fig. 58) and Leptochristina (Fig. 65), a medial and distal areas in Tanyproctus (Fig. 61), a basal, medial and distal areas in Pachydema (Fig. 55), and a medial and basal areas in Alaia (Fig. 66). Unordered.

\section{Distal sensilliferous area of endophallus}

(0) Absent (Fig. 58),(1) Present and covered with hook-shaped sensilla (Fig. 57h-ss, 67a); (2) Present and covered with fingerlike setae (Fig. $59 f_{s}$ ). This and the following characters referring to the morphology of the endophallus sensilla could not be scored for the outgroup representatives and the nonPalearctic genera because the morphology of their sensilla is very different from that of the Palearctic Pachydeminae so we could not establish the homologies (character inapplicable), The majority of genera of Palearctic Pachydeminae present a distinctive distal area covered with disperse hook-shaped sensilla (e.g. Pachydema (Fig. 55)). The small, finger-shaped sensilla are an autapomorphy of Pachydemocera (Fig. 59), whereas Ceramida (Fig. 58), Leptochristina (Fig. 65), Alaia (Fig. 66) and Elaphocera present a membranous distal area without sensilla. Unordered.

\section{Medial sensilliferous area of endophallus}

(0) Covered with flat finger-shaped setae (Fig. 57 wf-snf-5, 67 b,c); (1) Covered with two types of sensilla: simple trichoid setae (Fig. 58 sts, 67d) and convex finger-shaped setae (Fig. 58 $c f-s, 67 \mathrm{e}$ ); (2) Covered with imbricate trichoid setae (Fig. 59 its); (3) Covered with sensilla of very different morphologies (Fig. 68); (4) Covered with finger-like and hook-shaped sensilla (Fig. 66). Inapplicable in the outgroup (see ch49). The medial area is covered with flat finger-shaped sensilla in most genera of Pachydeminae (Figs 55, 57, 60, 61, 62, 63, 64, 65 and 69, 70). The other states are autapomorphies of Ceramida (state 1), Pachydemocera (2), Elaphocera (3) and Alaia (4), respectively. State 3 refers to the amazing variety of morphologies found in the endophallus of Elaphocera, which varies at the species or even at the population level (Fig. 68). Unordered.

\section{Basal sensilliferous area of endophallus}

(0) Absent (Fig. 58); (1) Present as a raspula of trichoid sensilla (Fig. 57 rts); (2) Present and covered with 'shark tooth'-shaped sensilla (Fig. 69 st-ss); (3) Present and covered with coneshaped sensilla (Fig. $64 c$-ss). Inapplicable in the outgroup (see ch49). Most genera of Pachydeminae present a membranous, indistinct basal area without sensilla (Ceramida (Fig. 58), 


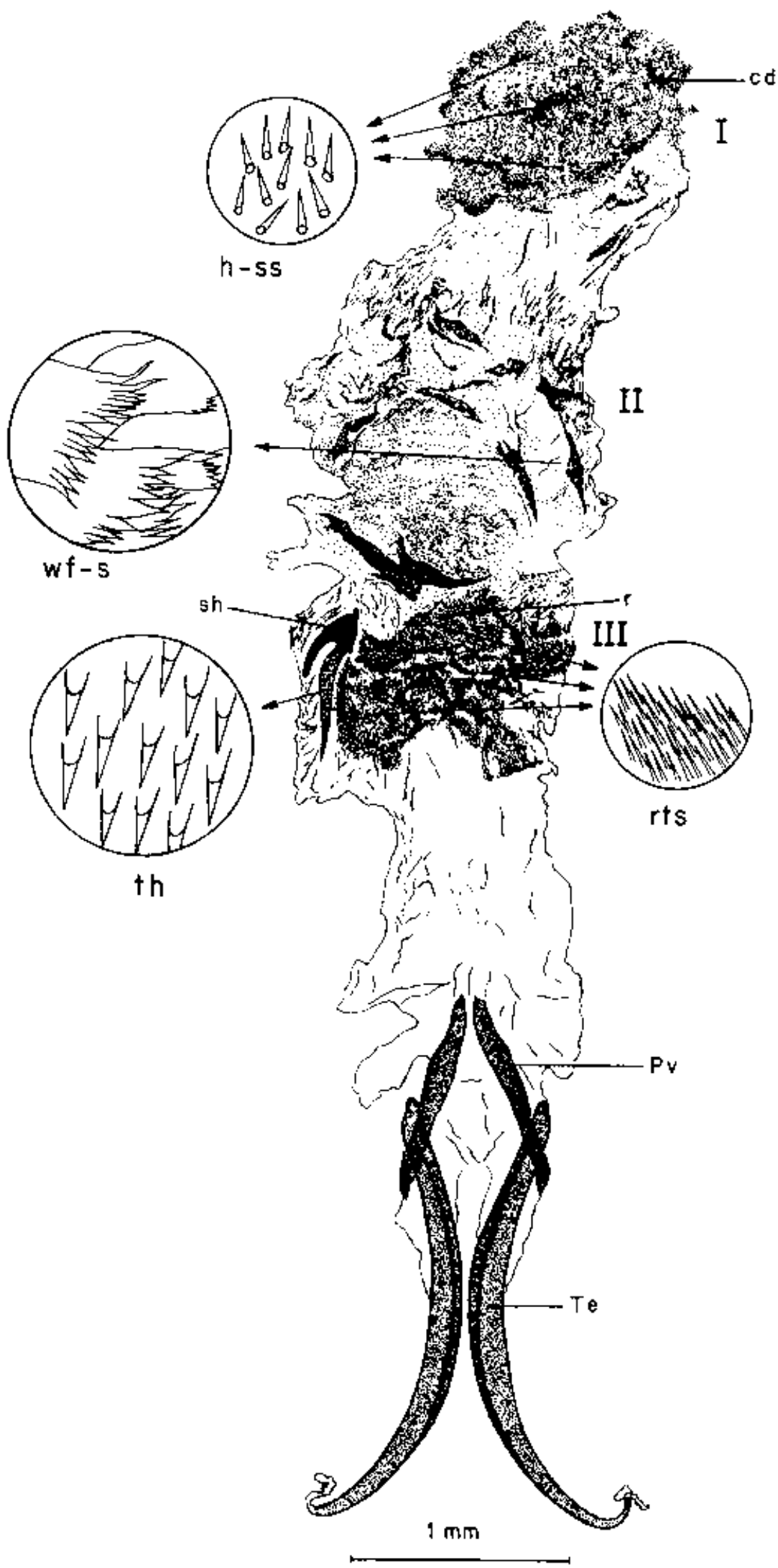

Fig. 55. Endophallus of Pachydeminae (Pachydema hirticollis), showing the division in areas with sensilla of different morphology: I (distal), II (medial), III (basal). Different morphologies of sensilla. Abbreviations: cd: caudal diverticle; h-ss: hook-shaped sensilla; Pv: V-shaped piece; r: raspulae; sh: hookshaped sclerotized structure; Te: temones; rts: raspulae of tricoid sensilla; th: detail of the teeth on the sclerotized structure; wf-s: wide flat finger-shaped sensilla

Pachydemocera (Fig. 59), Tanyproctus (Fig. 61), Tanyproctoides (Fig. 62), Otoclinius (Fig. 63), Leptochristina (Fig. 65), Brenskiella (Fig. 70) and Elaphocera). Pachydema (Fig. 55) and Hemictenius (Fig. 57) present a raspula of sensilla surrounding a sclerotized structure. The tooth-shaped sensilla are autapomorphic of Europtron (Fig. 69), and the coneshaped sensilla are present in Atanyproctus miksici (Fig. 64) and Alaia (Fig. 66). Unordered. 

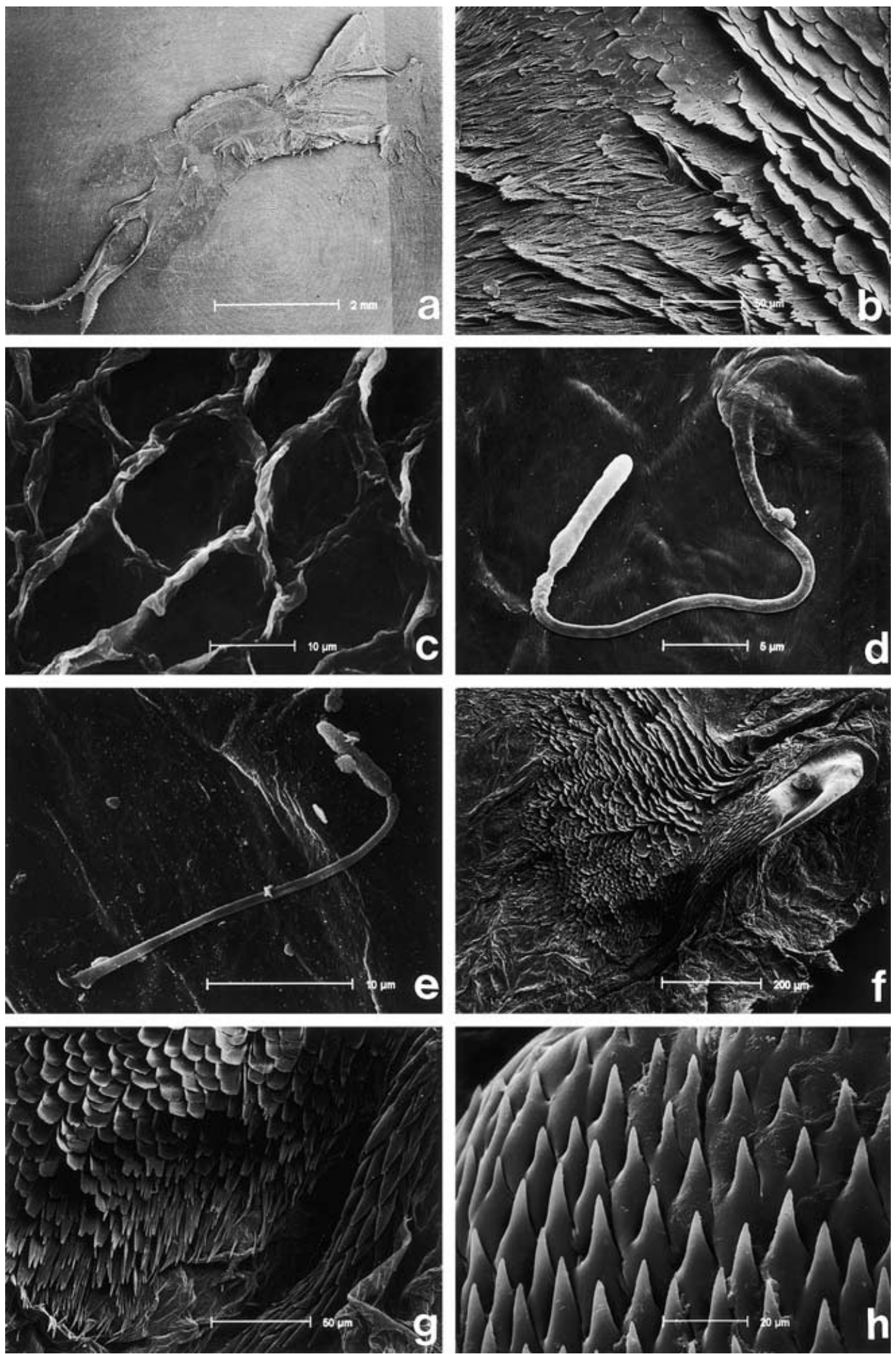

Fig. 56. Scanning electron micrographs of the endophallus of Elaphocera alonsoi, showing (a) endophallus (b) external surface of the endophallus with sensilla (c) internal surface of the endophallus and (d-e) spermatozoids. Endophallus of Pachydema hirticollis, showing (f) hook-shaped sclerotized structure with raspulae $(\mathrm{g})$ detail of the raspulae and (h) detail of the teeth on sclerotized structure

\section{E Female genitalia}

As in Melolonthinae (Coca-Abia and Martín-Piera 1991), the female genitalia of Pachydeminae is of the tubular type
(Lindroth and Palmén 1970). It comprises a genital chamber, accessory glands, median oviduct, bursa copulatrix, oviduct, spermatheca and spermathecal gland (Fig. 71). The fecundation 


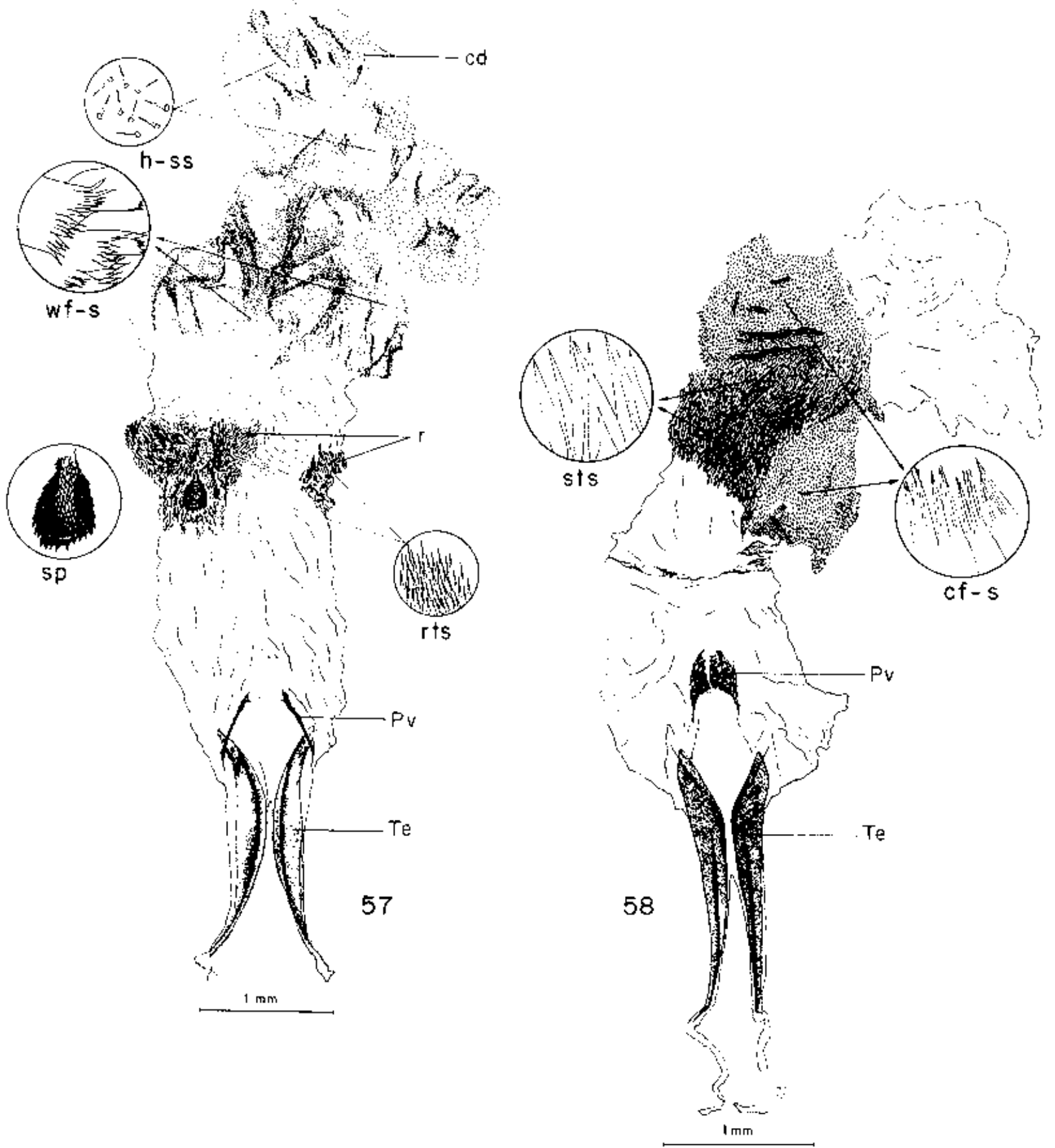

Figs 57, 58. Different types of endophallus in Pachydeminae: (57) Hemictenius nigrociliatus and (58) Ceramida lusitanica [synonymy of C. malacensis (Sanmartín and Martín-Piera 1999b)]. Abbreviations: cd: caudal diverticle; cfs: convex finger-shaped sensilla; h-ss: hook-shaped sensilla; Pv: V-shaped piece; r: raspulae; rts: raspulae of trichoid sensilla; sp. sclerotized plate; sts: simple trichoid sensilla; Te: temones; wf-s: wide flat finger-shaped sensilla

presumably takes place inside the median oviduct, a wide wrinkled camera where the bursa copulatrix, spermatheca and oviduct meet separately (Zunino and Monteresino 1990; CocaAbia and Martín-Piera 1991). Female genitalic structures are usually membranous and less specific than those in the male genitalia, providing characters at the generic level. This lack of specificity does not agree with the lock-and-key hypothesis. On the contrary, the presence of presumably sensory setae in the genital chamber and bursa copulatrix of the female seems to support the 'internal courtship' hypothesis (Eberhard 1985; Zunino 1987).

\section{Vestigial sternites of genital chamber}

(0) Fused to genital palps (Fig. 72); (1) Separated from genital palps (Fig. 73). This character could not be scored for Aplidia because this genus lacks genital palps, and it varies in the rest 

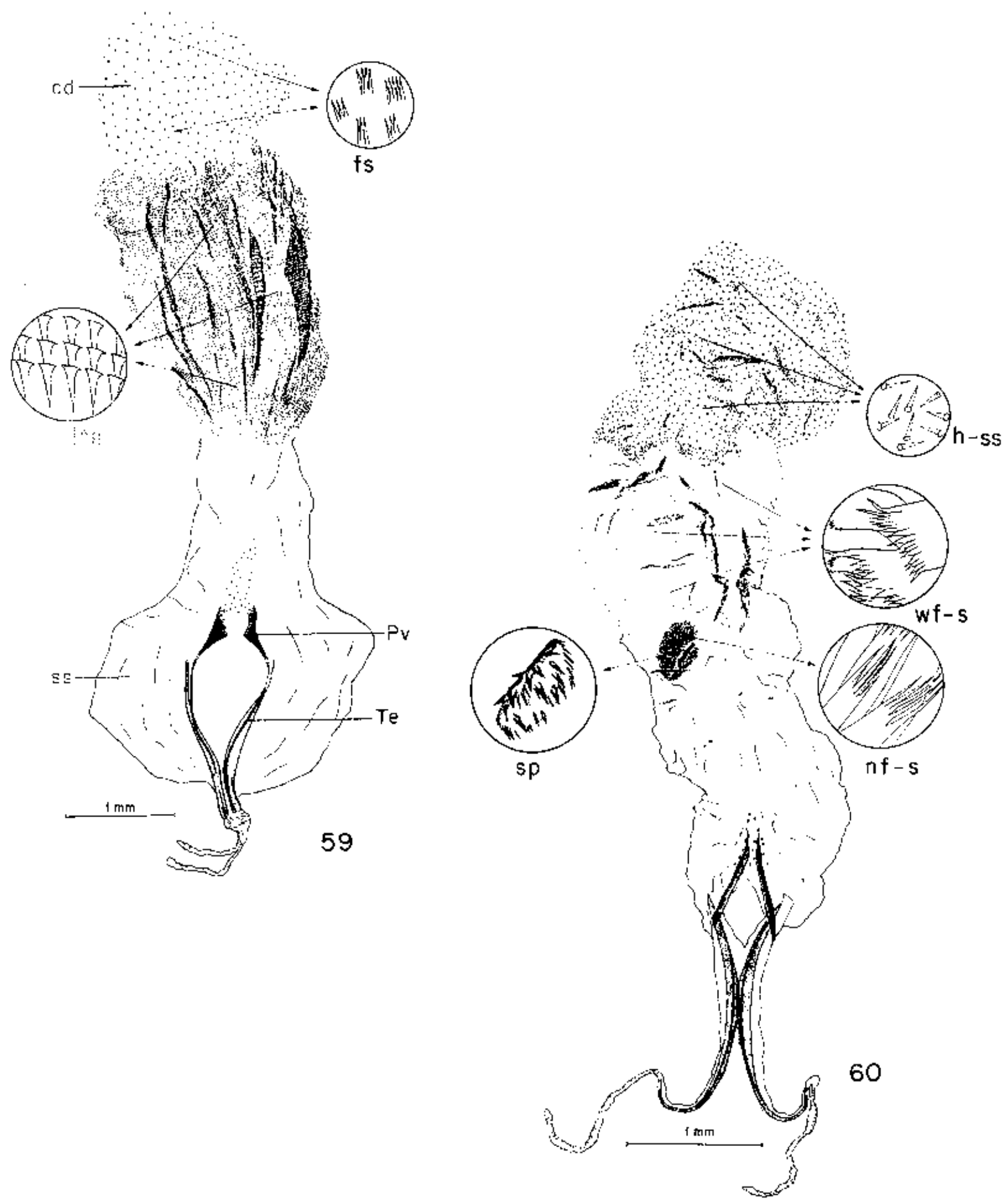

Figs 59, 60. Different types of endophallus in Pachydeminae: (59) Pachydemocera lucidicollis and (60) Pachydema menieri. Abbreviations: cd: caudal diverticle; fs: finger-like sensilla; h-ss: hook-shaped sensilla; its: imbricated trichoid sensilla; nf-s: narrow flat finger-shaped sensilla; Pv: V-shaped piece; ss, secondary sac; sp. sclerotized plate; Te: temones; wf-s: wide flat finger-shaped sensilla

of outgroups. The genital chamber is the caudal extension of the oviduct, and is located at the posterior end of the VIII segment (Coca-Abia and Martín-Piera 1991). This chamber opens to the outside through the vaginal ostium or vulva
(Fig. $71 V$ :), and probably has a copulatory function. Unlike Melolonthinae (Coca-Abia 1995), the anus does not open directly to the dorsal wall of the genital chamber but to a socket-like fold, the 'anal fold', on the dorsal wall of the 


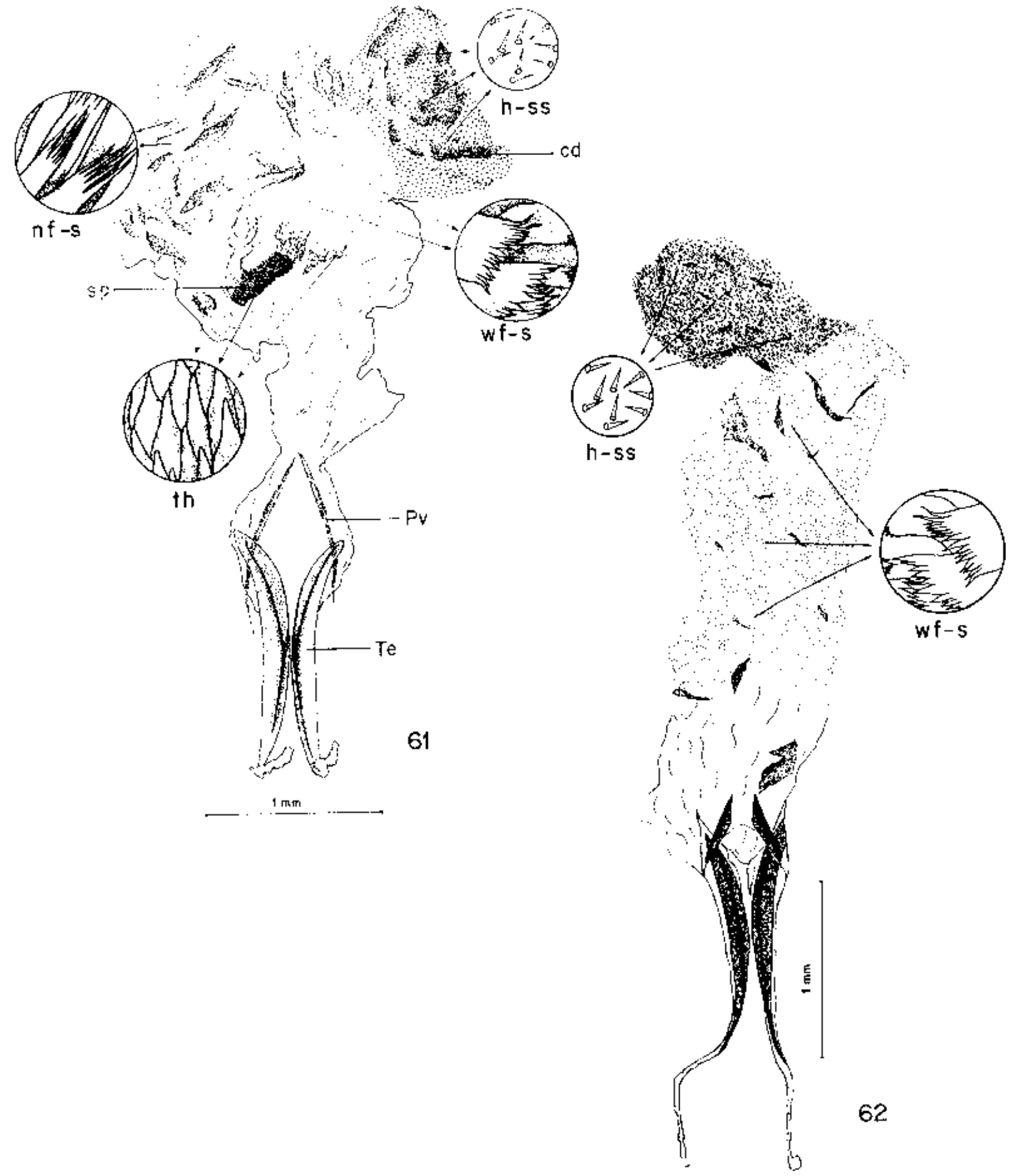

Figs 61, 62. Different types of endophallus in Pachydeminae: (61) Tanyproctus reichei and (62) Tanyproctoides arabicus. Abbreviations: cd: caudal diverticle: h-ss: hook-shaped sensilla; nf-s: narrow flat finger-shaped sensilla; Pv: V-shaped piece; sp. sclerotized plate; Te: temones; th: detail of the teeth on the sclerotized structure; wf-s: wide flat finger-shaped sensilla

chamber (Fig. $71 a f$ ). On both sides of this fold, there is a pair of small vestigial tergites (1vt) and a second pair of larger tergites $(2 \mathrm{vt})$ extending to the ventral side. The ventral wall of the genital chamber presents a pair of large vestigial sternites of variable morphology (VS), and a second smaller pair, the 'genital palps' or 'styli' (gp), extending forwards into the anterior end of the genital chamber. The vulva is placed between both pairs of sternites. The vestigial tergites are derived from the IX segment, whereas the vestigial sternites are derived from either the VIII segment (Zunino and Monteresino 


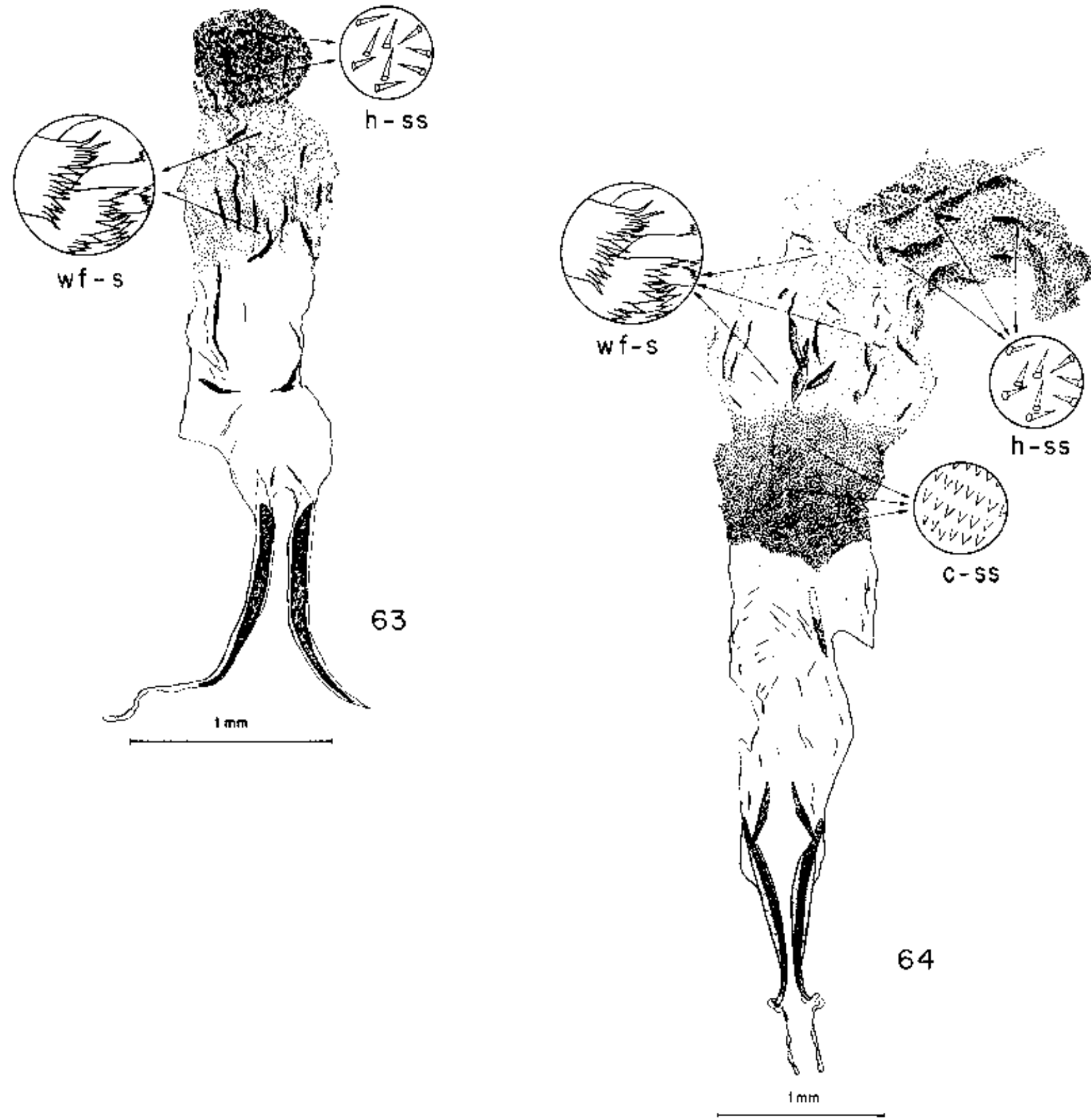

Figs 63, 64. Different types of endophallus in Pachydeminae: (63) Otoclinius gracilipes and (64) Atanyproctus miksici. Abbreviations: c-ss: coneshaped sensilla; h-ss: hook-shaped sensilla; wf-s: wide flat finger-shaped sensilla

1990) or the IX segment (Krell 1996). These sclerites are externally covered with fine setae. In Ceramida and Elaphocera, the vestigial sternites are partially fused (Fig. 72), whereas in Tanyproctus (Fig. 73), Pachydema, and Hemictenius, the genital palps and the sternites are independent structures. According to Eberhard (1992, 1993), the genital chamber is an active mechanism in sexual selection by female choice (SSFCh) in Melolonthidae. Females can prevent the male endophallus from reaching the oviduct by contracting the muscles in the vulva, whereas the setae of the female genital sclerites and those of the male apices of parameres probably interact during the male 'internal courtship'.

\section{Bursa copulatrix}

(0) Internally covered with setae (Figs 74 and 75); (1) Without setae (Figs 76 and 77). The bursa copulatrix is a wide pedunculated diverticle ending in a globous pouch, which opens to the dorsal wall of the median oviduct (Fig. $71 \mathrm{Bc}$ ). It is presumably derived from the Xth segment or the intersegmental area IX/X, like the aedeagus (Krell 1996). Its function is the storage and enzymatic digestion of the spermatophore after removal of the sperm (Krell 1996). The bursa copulatrix may also act as a SSFCh mechanism when the spermatophore is digested before the removal of the male sperm (Eberhard 1992). The bursa copulatrix is internally lined with smal 

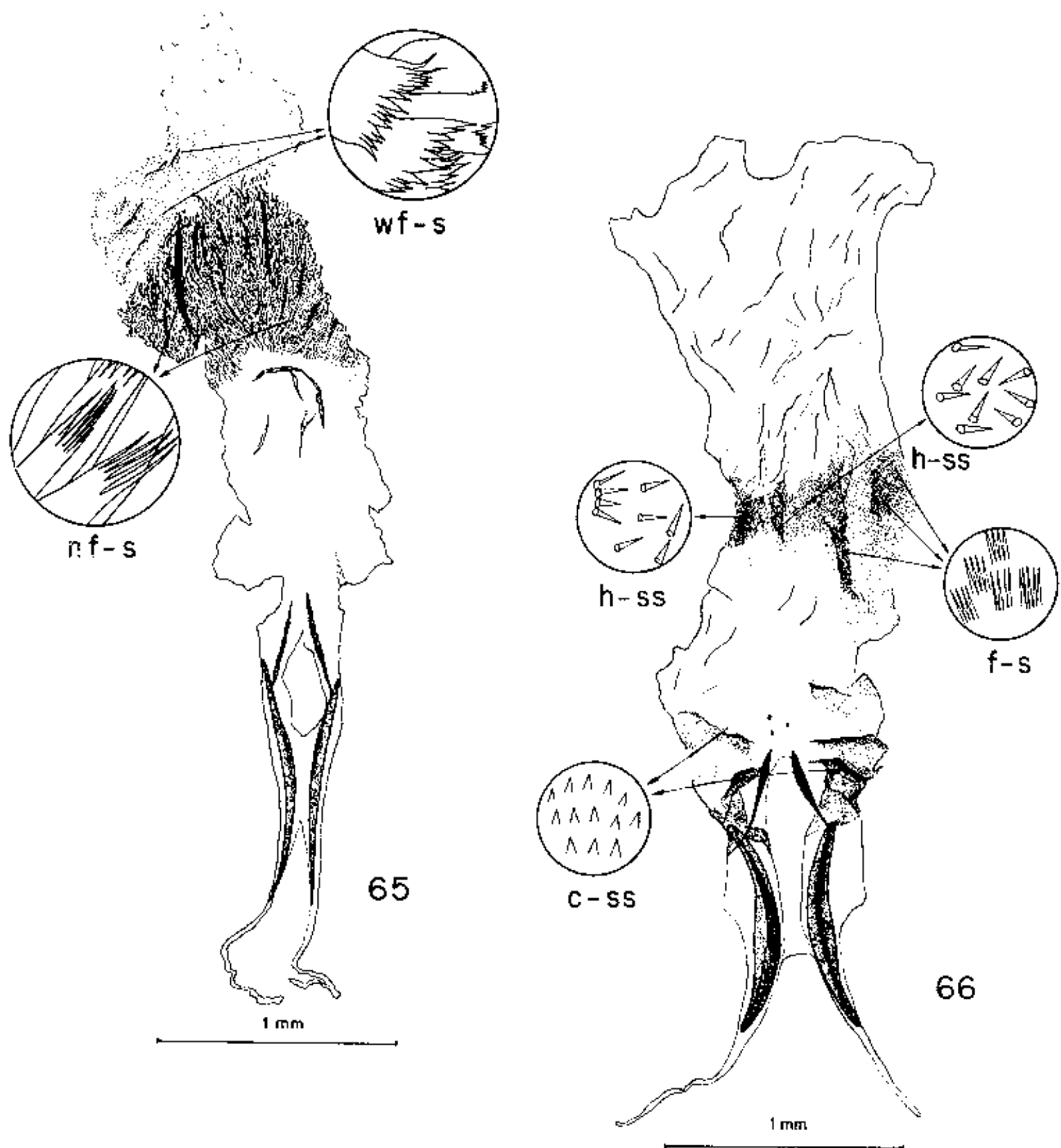

Figs 65, 66. Different types of endophallus in Pachydeminae: (65) Leptochristina pubimargo and (66) Alaia sexdentata. Abbreviations: c-ss: coneshaped sensilla; fs: finger-like sensilla; h-ss: hook-shaped sensilla; nf-s: narrow flat finger-shaped sensilla; wf-s: wide flat finger-shaped sensilla

punctiform setae, presumably of presso-sensorial function, in Pachydema (Fig. 74), Hemictenius (Fig. 75), except H. tekkensis, and the outgroups Melolontha, Polyphylla and Aplidia. We could not ascertain the presence of setae in Pseudotrematodes but Euserica lacks setae. The alternate state (simple bursa) is present in Ceramida (Fig. 71), Tanyproctus (Fig. 76), and Elaphocera (Fig. 77).

\section{Peduncle of bursa copulatrix}

(0) Without setae (Fig. 75); (1) Internally covered with setae (Fig. 76); (2) Covered with sclerotized structures. The most widespread condition in Pachydeminae is a peduncle without setae (e.g. Hemictenius, Ceramida, Elaphocera), whereas a hairy peduncle is found in Tanyproctus and Pachydema anthracina.
Both conditions are present alike in the Melolonthinae, whereas the peduncle of Euserica is covered with sclerotized structures.

55 Oviduct

(0) Without a distinctive area of setae; (1) With sclerotized setae covering most of the length of oviduct (Fig. 77), (2) With sclerotized setae covering only half of the length of oviduct (Fig. 74). The oviduct (also called 'common oviduct') opens to the ventral wall of the median oviduct, opposite to the bursa copulatrix (Fig. $71 O$ ). It is usually internally lined with strongly sclerotized and triangular-shaped sensilla. Some genera of Pachydeminae (Ceramida, Elaphocera) and most outgroups present an oviduct entirely covered with sensilla (state 1), whereas the oviduct of Tanyproctus, Pachydema and 

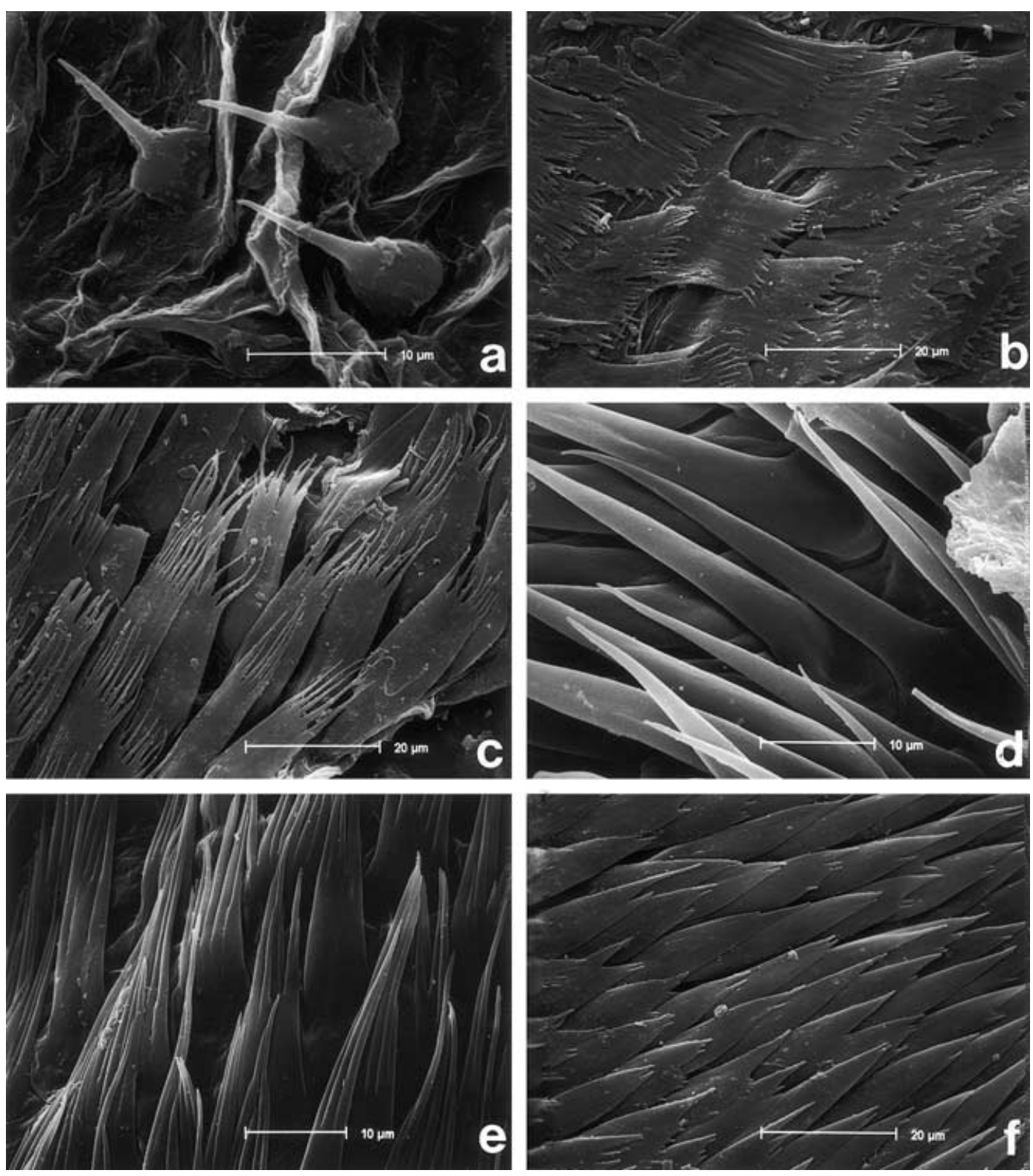

Fig. 67. Scanning electron micrographs showing different morphologies of the sensilla in the endophallus: (a) hook-shaped (b-c) wide (b)-narrow (c) flat finger-shaped (d) simple trichoid (e) convex finger-shaped and (f) other morphology

Hemictenius is only partially lined with setae (state 2 ). State 0 is autapomorphic for Pseudotrematodes.

\section{Length of the spermathecal conduct relative to length} of the pouch

(0) Conduct distinctly longer than pouch (Figs 76 and 77); (1) Equal to or shorter than pouch (Figs 74 and 75). The spermatheca or receptaculum seminis opens to the dorsal wall of the median oviduct (Fig. $71 \mathrm{~S}$ ). Its function is the storage of the sperm after it has been removed from the bursa copulatrix. The spermatheca is divided into two different tracts: a distal ringed pouch or sac and a proximal conduct, which joins to the median oviduct. The length of the conduct relative to the distal pouch varies among genera and species within genera in Pachydeminae (it is also variable in the outgroups). It is distinctly longer in Ceramida, Elaphocera and Tanyproctus subciliatus Reitter, 1902 (state 0 ) but shorter (usually thick and ringed) in Hemictenius, Pachydema, and Tanyproctus reichei.
57 Relative position of the spermathecal gland pore on the spermatheca

(0) Distal: the gland is inserted at the end of the conduct of the spermatheca (Fig. 74); (1) Proximal: the gland is inserted at the beginning of the conduct of the spermatheca (Fig. 75); (2) Medial: the gland is inserted at the middle of the conduct of the spermatheca (Figs 76 and 77). The spermathecal gland is responsible for guiding the spermatozoids from the bursa copulatrix to the spermatheca. This is done by means of a glandular secretion gradient (Krell 1996). The spermathecal gland is divided into two tracts: a distal pouch and a thin proximal conduct, which joins the spermatheca at different positions: distal in Pachydema and most outgroups (e.g. Euserica), proximal in Hemictenius and Polyphylla, or medial in Elaphocera. In Ceramida and Tanyproctus the character varies at the species level. Unordered. 

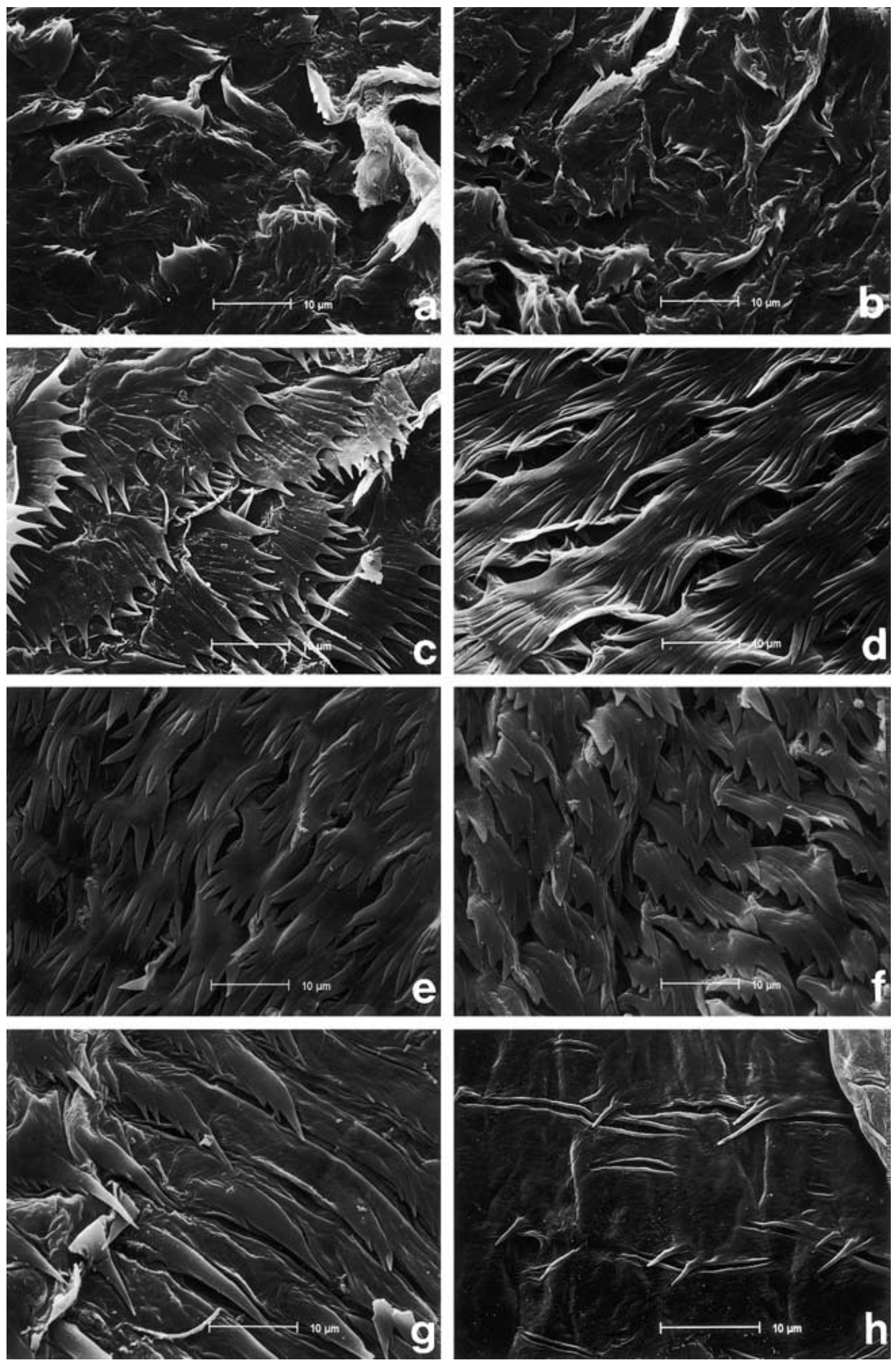

Fig. 68. Scanning electron micrographs showing different morphologies of sensilla that can be found in the endophallus of Elaphocera carteiensis

58 Shape of spermatheca

(0) Narrow throughout (Fig. 74); (1) Terminally widened in a global caecum (Fig. 76); (2) Wide throughout, 'barrel'-shaped (Fig. 77). A narrow throughout spermatheca (0) is found in all the outgroup representatives, Pachydema and Tanyproctus reichei, whereas Ceramida and Tanyproctus subciliatus present a terminally widened spermatheca (1), and Elaphocera and Hemictenius (except for H.tekkensis), a barrel-shaped spermatheca. 

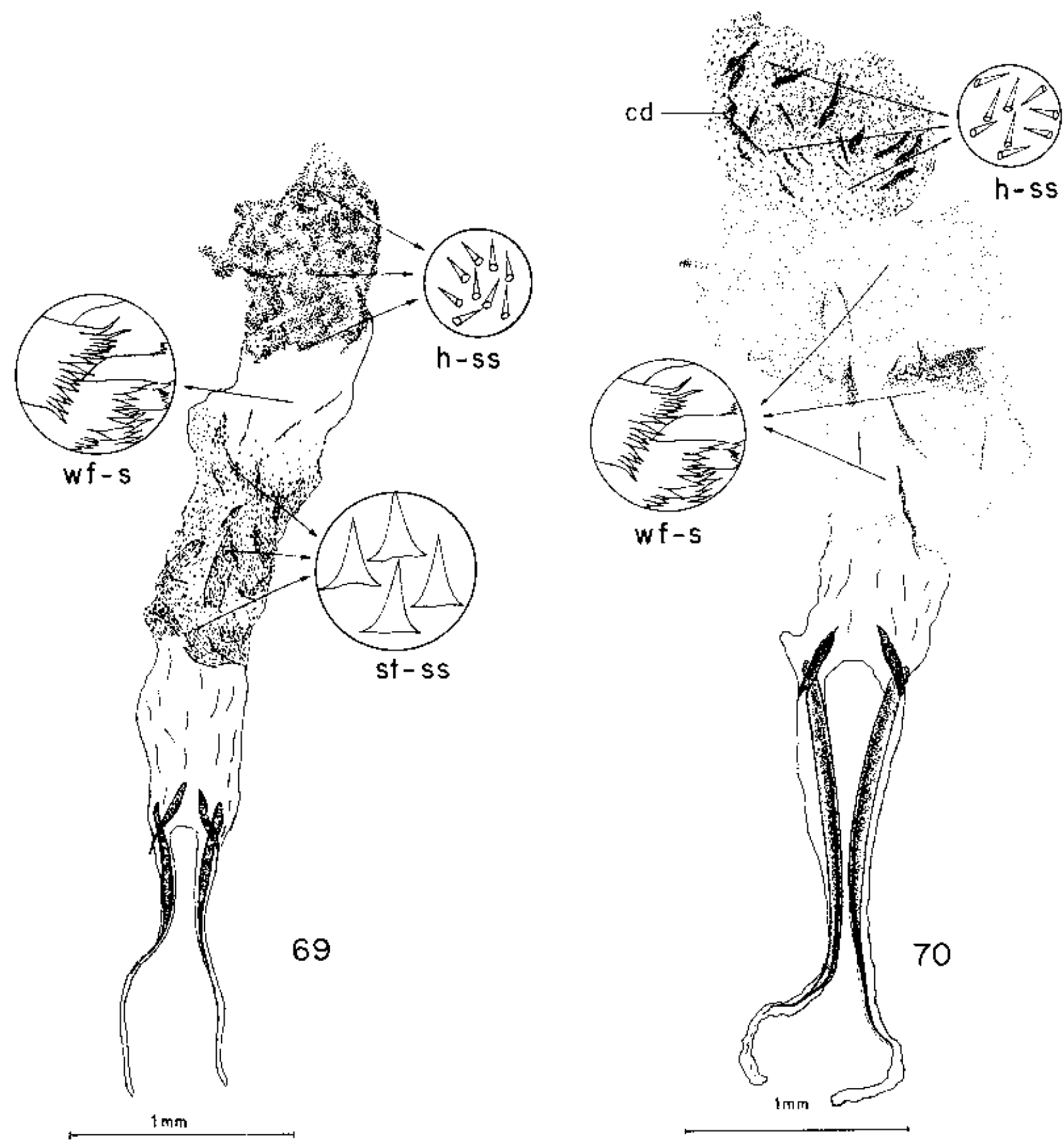

Figs 69, 70. Different types of endophallus in Pachydeminae: (69) Europtron gracile and (70) Brenskiella flavomicans. Abbreviations: cd: caudal diverticle; h-ss: hook-shaped sensilla; st-ss: shark tooth-shaped sensilla; wf-s: wide flat finger-shaped sensilla

59 Shape of spermathecal gland

(0) Pear-shaped (Fig. 74); (1) Spheric (Fig. 77). All outgroup representatives and most genera of Pachydeminae present a pear-shaped spermathecal gland (e.g. Pachydema, Fig. 74). The spheric spermatheca is an autapomorphy of Elaphocera.

60 Size of accessory gland I ( $\mathrm{Ag}$ I) relative

to accessory gland II ( $\mathrm{Ag}$ II)

(0) $\mathrm{Ag} \mathrm{I}$ is less than three times the size of Ag II (Figs 78 and 79); (1) More than three times the size of Ag II (Fig. 80). This character could only be scored for the outgroups Melolontha,
Euserica (0) and Aplidia (1) because Pseudotrematodes and Polyphylla present only one pair of accessory glands. The female genitalia of Pachydeminae present two pairs of accessory glands, which open through a common duct into the base of the median oviduct (Fig. 71, $A g I, I I$ ). Their function is probably the production of pheromones for sexual attraction (Zamotailov 1988). Analogous glands found in the male genitalia of Blatta (Feliú-Badaló et al. 1996) and Drosophila (Harshman 1996) have been related to mechanisms of sperm competition. The two pairs of glands are of different size, Ag I being always larger than Ag II. In most Pachydeminae, this 


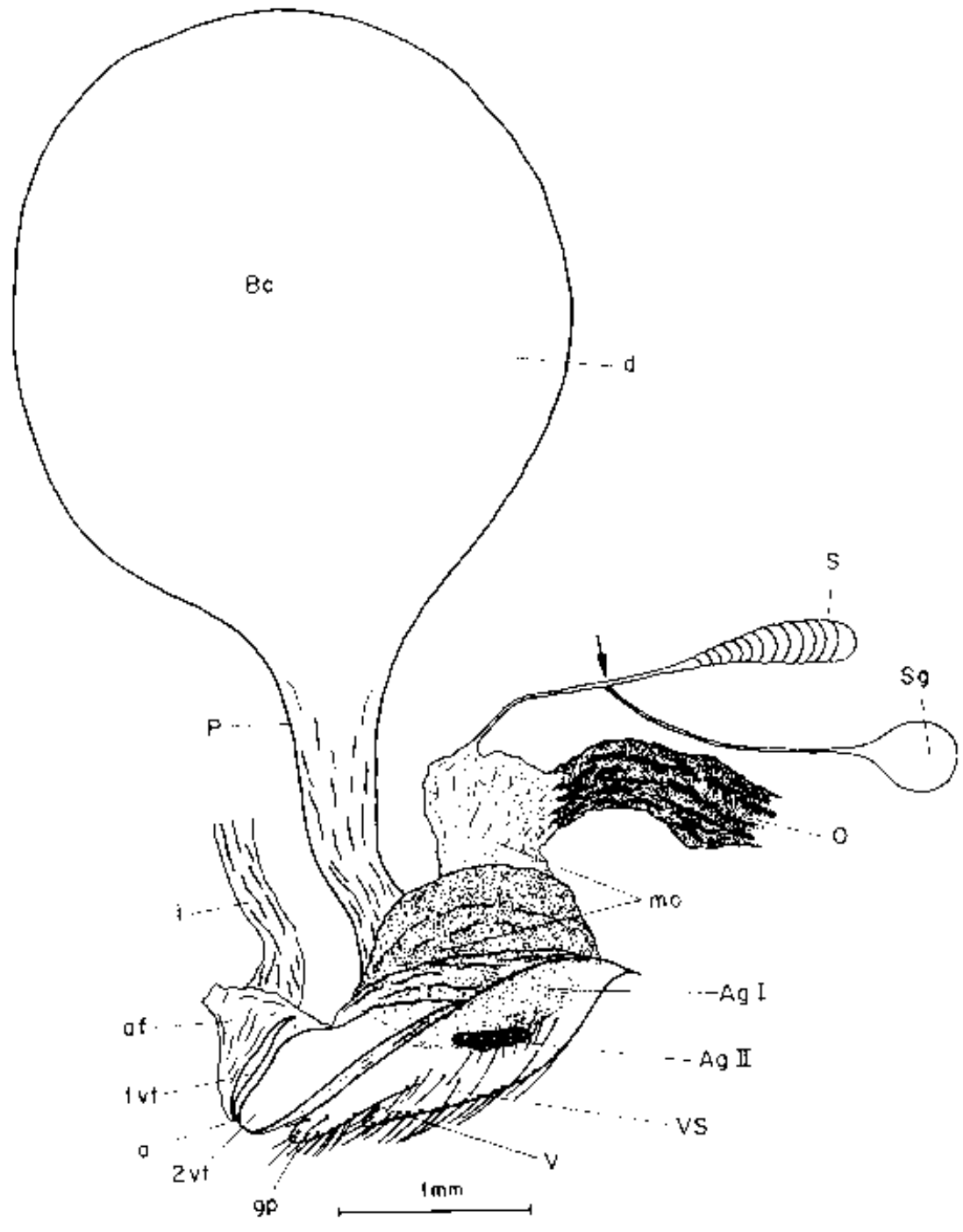

Fig. 71. Lateral view of the female genitalia of Pachydeminae (Ceramida tangeriana, synonymy of $C$. malacensis (Sanmartín and Martín-Piera (1999b)), showing the different organs. Abbreviations: a: anus; af: anal fold; AgI, AgII: accessory glands; Bc: bursa copulatrix; d: diverticle of the bursa copulatrix; gp: genital palps; i: intestine; mo: median oviduct; O: oviduct; P: peduncle of the bursa copulatrix; S: spermatheca; Sg: spermathecal gland; $\mathrm{V}$ : vulva; 1vt, 2vt: vestigial terguites; VS: vestigial sternites

difference is small but in Ceramida (Fig. 80), Ag I is more than three times larger than Ag II.

61 Setae of accessory gland I ( Ag I)

(0) Trichoid setae arranged in a curved, transverse row ('eyelash') (Fig. 78); (1) Basiconic setae arranged in scales (Fig. 79); (2) Simple, thick trichoid setae (Fig. 80); (3) Very long and fine trichoid setae. This and the following characters referring to gland pubescence were only scored for Melolontha among the outgroups because the others present setae whose morphology is very different to the ingroup (inapplicable). The accessory glands of Pachydeminae are internally lined with sensilla of variable morphology. The trichoid setae (0) are the most frequent (Pachydema, Hemictenius, Tanyproctus subciliatus), whereas the simple trichoid setae (2) are present in Ceramida and Melolontha. The basiconic setae (1) and the long fine trichoid setae (3) are autapomorphic for Elaphocera and Tanyproctus reichei, respectively. Unordered.

62 Setae of accessory gland II ( Ag II)

(0) Very long and fine trichoid setae (Figs 78 and 79); (1) rhombus-shaped plaques (Fig. 80). This character was only scored for Melolontha among the outgroups (see ch61), which presents the same character state as Ceramida, rhombus-shaped plaques. The rest of Pachydeminae present long trichoid setae (Elaphocera, Hemictenius, Pachydema, Tanyproctus).

63 Shape of accessory gland II ( Ag II)

(0) Flat and rigid (Fig. 80); (1) Flat and turgid (Fig. 79); (2) Convex, kidney-shaped (Fig. 78). A flat and rigid Ag II is found in Ceramida and the outgroup Melolontha. The most frequent state in Pachydeminae is a kidney-shaped gland (2), present in Pachydema, Hemictenius, Tanyproctus (and Euserica), whereas a flat and turgid gland is autapomorphic for Elaphocera (1). Unordered.

\section{Phylogenetic relationships}

The Ratchet Parsimony search of NONA and WINCLADA (200 iterations, $10 \%$ of characters) yielded 32 most parsimonious trees (MPTs) of 284 steps [consistency index (CI), 0.35, retention index (RI), 0.77]. We repeated the search five times obtaining the same statistics as above. According to Sanderson and Donoghue (1989), the observed homoplasy (CI, 0.35) is slightly lower than expected for a data set of this size (56 taxa, CI, 0.33). Figure 81 is the strict consensus of the MPTs ( $\mathrm{L}=294, \mathrm{CI}, 0.34, \mathrm{RI}, 0.76$ ). We now discuss the grouping and the characters supporting each group. Reconstructing charac- 

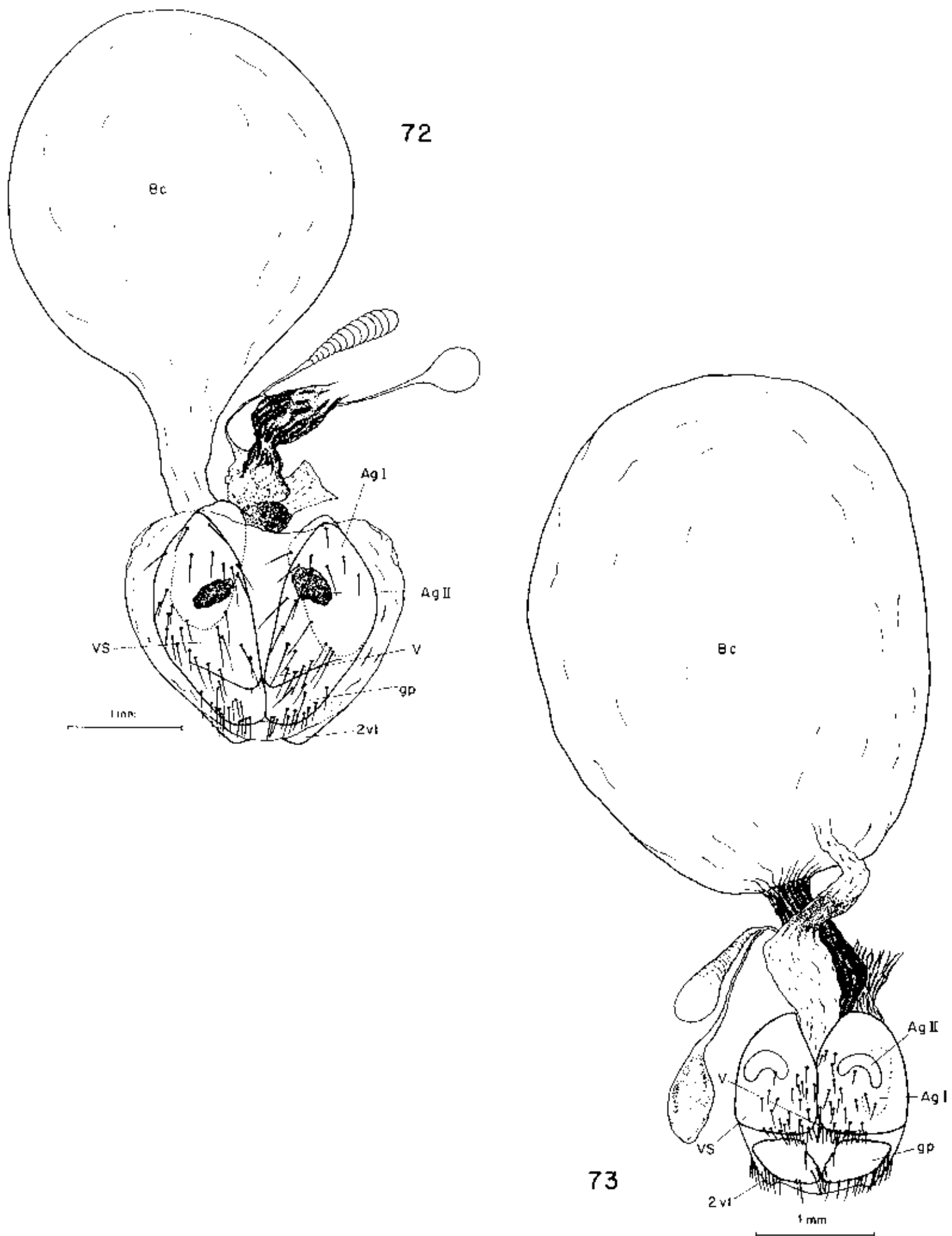

Figs 72, 73. Ventral view of the female genitalia of (72) Ceramida tangeriana (synonymy of C. malacensis [Sanmartín and Martín-Piera (1999b)] and (73) Tanyproctus subciliatus. Abbreviations as in Fig. 71 

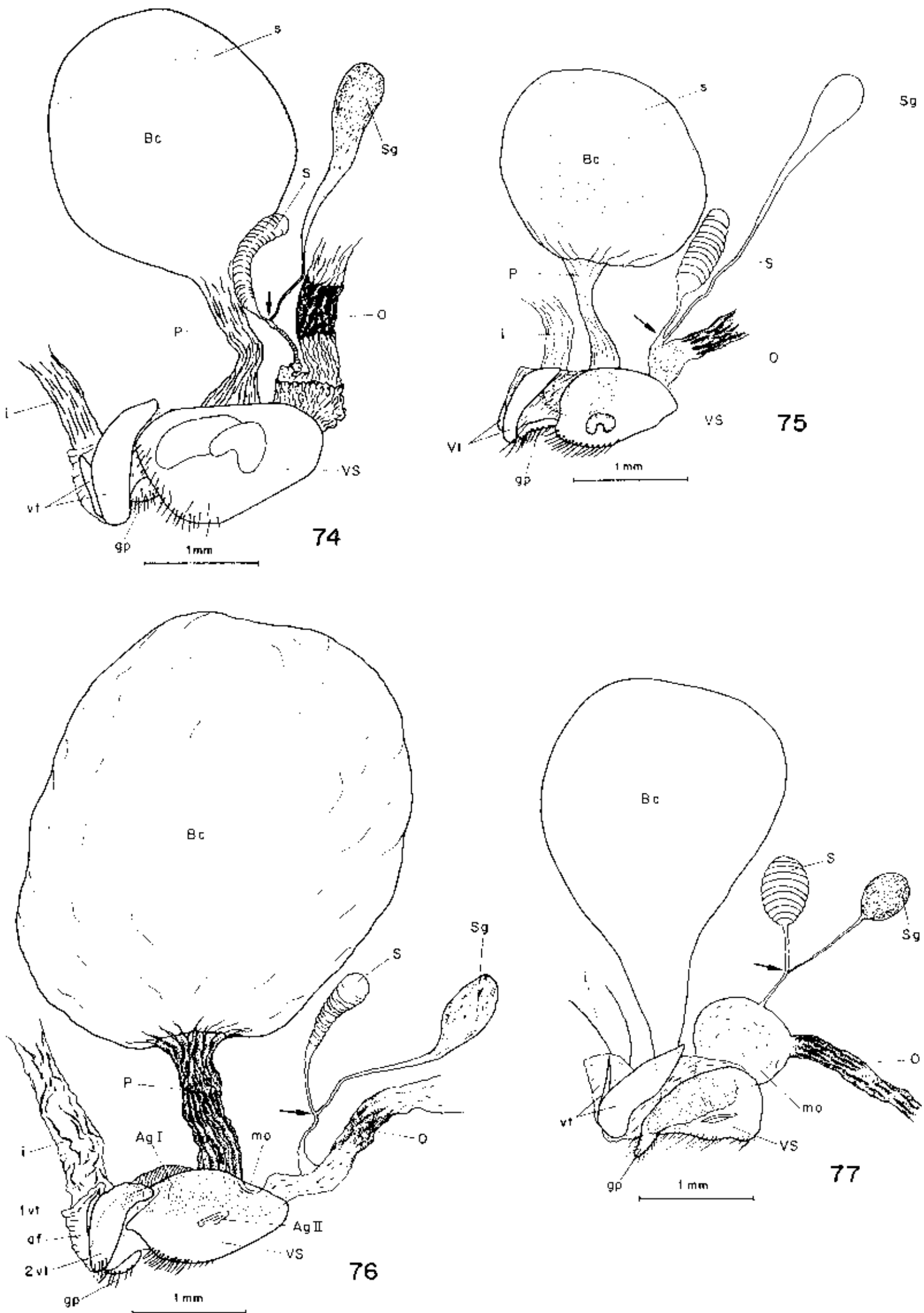

Figs 74-77. Different types of female genitalia of Pachydeminae in lateral view: (74) Pachydema xanthochroa (75) Hemictenius opacipes (76) Tanyproctus subciliatus (77) Elaphocera capdeboui. Abbreviations: s: setae of the bursa copulatrix; the rest of abbreviations as in Fig. 71 


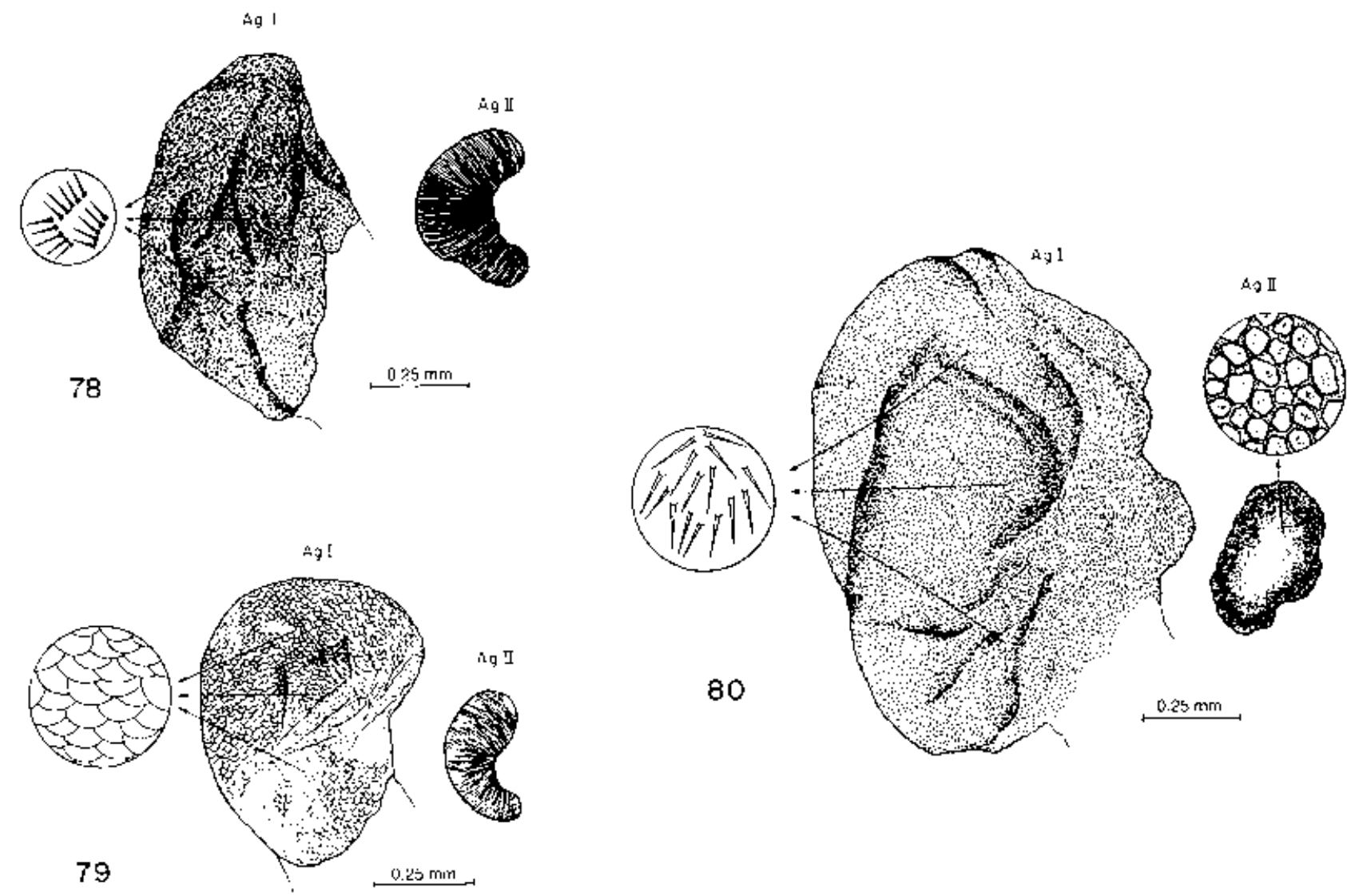

Figs 78-80. Female accessory glands (Ag I, Ag II) of (78) Tanyproctus subciliatus (79) Elaphocera alonsoi, and (80) Ceramida bedeaui

ter evolution on a consensus tree is not recommendable because it requires tracing character changes in polytomies and the reconstruction might not be the most parsimonious one (Maddison and Maddison 1992). Figure 82 shows one of the 32 MPTs with the characters mapped on it. For each supporting character we list the corresponding state shared by the clade being discussed (e.g. character $4^{0}$ means character 4, state 0). However, conclusions about monophyly of the genera and their relationships would be based on the strict consensus of Fig. 81 because it presents those groupings strictly supported by the data (Nixon and Carpenter 1996).

(1) As expected, the phylogeny indicates a closer relationship between the Pachydeminae and the Melolonthinae than to the Sericinae (Fig. 81). It also supports Coca-Abia (1995)'s division of Melolonthinae into two tribes: Melolonthini (MelolonthaPolyphylla) and Rhizotrogini (Pseudotrematodes - Aplidia). More important for this study is the fact that the Palearctic genera of Pachydeminae form a monophyletic group within the subfamily. The monophyly is supported by four synapomorphies (Fig. 82): five-segmented antennal clubs $\left(2^{1}\right)$, fifth and sixth abdominal sternites separated by a thick membrane $\left(16^{1}\right)$, pro- and mesotarsal joints enlarged $\left(20^{1}\right)$ and covered on the inner surface with a brush of small setae $\left(19^{2}\right)$, and three additional character state changes: ridge on posterior margin of pronotum $\left(13^{0}\right)$, long parameres relative to phallobase $\left(36^{0}\right)$, and V-shaped piece reaching temones $\left(46^{\circ}\right)$. The Melolonthinae are also separated from the Pachydeminae by one synapomorphy: abdominal sternites fused at middle $\left(15^{0}\right)$, as well as seven character states that otherwise appear in other parts of the phylogeny of Pachydeminae: last funicular segment 'cup-shaped' $\left(4^{0}\right)$, frons not pubescent $\left(7^{0}\right)$, basally toothed male claws $\left(21^{\circ}\right)$, last segment of maxillary palps with ventral excavation $\left(27^{0}\right)$, square labium $\left(30^{\circ}\right)$, weak dorsal strangulation in the phallobase $\left(37^{\circ}\right)$, and apex of parameres with no lateral processes $\left(43^{0}\right)$.

Unexpectedly, however, the Afrotropical Pachydeminae Sparrmannia is included within the Melolonthinae, whereas the Nearctic Phobetus is placed as the sister group to the Palearctic Pachydeminae. Of the four synapomorphies mentioned above that separate the Palearctic from the nonPalearctic genera, enlarged and hairy tarsal segments (chs. $19^{2}-20^{1}$ ) can be found in some Afrotropical genera (Lacroix 1997), whereas the presence of an abdominal membrane between the fifth and sixth segments $\left(16^{1}\right)$ is problematic. Although this membrane is generally considered as a synapomorphy of Pachydeminae (Baraud 1992; Lacroix 2000), it is not clear that all non-Palearctic genera present it (see character description). Furthermore, coding both genera as presenting this membrane $\left(\mathrm{ch} 16^{1}\right)$ did not change the topology of the cladogram, except for a loss of resolution in Tanyproctus. However, because both Sparrmannia and Phobetus are missing for all female characters, their placement in the cladogram and the monophyly of the Palearctic Pachydeminae should be taken with caution. On the other hand, Sanmartín and Martín-Piera (in prep.) have found differences in larval morphology between the Nearctic Phobetus and those Palearctic genera for which larvae have been described (Ceramida, Hemictenius, Pachydema and Tanyproctus). These characters are related to the 


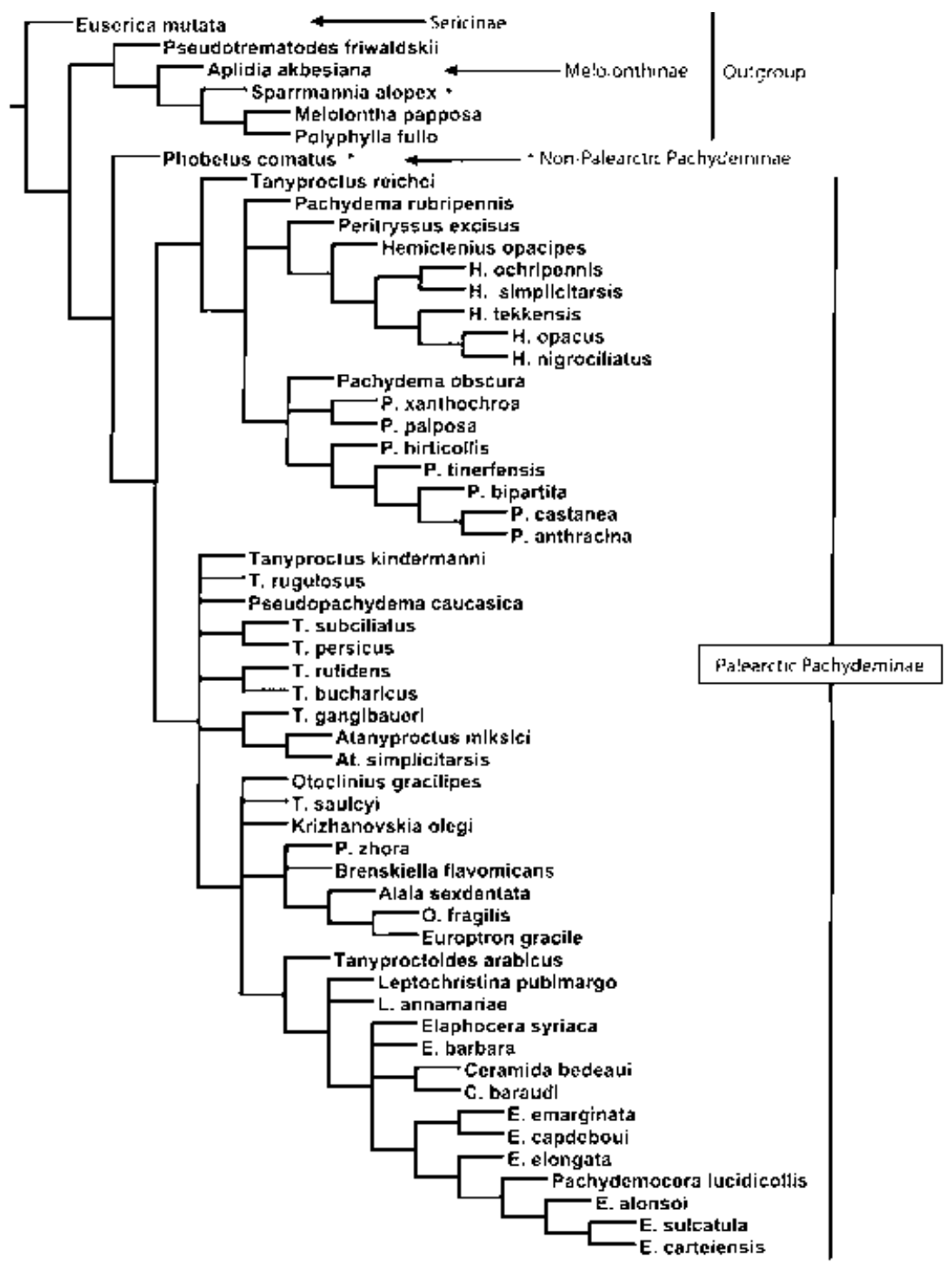

Fig. 81. Phylogeny of the Palaeartic Pachydeminae. Strict consensus of 32 most parsimonious trees of 284 steps, $\mathrm{CI}=0.35$, $\mathrm{RI}=0.77$ ), obtained with the parsimony ratchet search (200 iterations, 6 characters per iteration) (Nixon 1999) setation of head and last abdominal segment and the degree of reduction of metatarsal legs.

(2) The most basal split within the Palearctic Pachydeminae is between a clade including the monospecific Peritryssus, Tanyproctus reichei, and the large genera Pachydema and Hemictenius, and a second clade including the rest of genera (Fig. 81). The first clade is supported by two character states (Fig. 82): square labium $\left(30^{\circ}\right)$ and conduct of the spermatheca as long or shorter than the pouch $\left(56^{1}\right)$. Tanyproctus reichei is placed basally in this clade. As mentioned above, the classification of this species in Tanyproctus is problematic because it shares character state with Pachydema and Hemictenius for most mouthpart $\left(28^{0}-30^{\circ}\right)$ and genitalic characters $\left(45^{0}, 56^{1}, 58^{0}\right)$, instead of with the rest of Tanyproctus species $\left(28^{1}-30^{1}, 45^{1}, 56^{0}, 58^{1}\right)$. Pachydema and Hemictenius ( + Peritryssus) form a monophyletic group, in polytomy with $P$. rubripennis, which is the sister-group to T. reichei (Fig. 81). Four character states support this sister group relationship (Fig. 82): last segment of maxillary palps with a distinct, excavated area $\left(27^{\circ}\right)$, endophallus with three areas of sensilla $\left(48^{2}\right)$, basal area of endophallus with a raspula of trichoid sensilla $\left(51^{1}\right)$ and bursa copulatrix internally lined with setae $\left(53^{0}\right)$. Peritryssus is placed as the sister group to Hemictenius but the relationship is only supported by pubescent margin of pronotum $\left(9^{1}\right)$ and the sharp apex of parameres $\left(42^{0}\right)$. Moreover, some important male genitalic characters of Peritryssus could not be coded because of the poor state of conservation of the holotype (the only known specimen). The inclusion of the monospecific Peritryssus within the Palearctic Pachydeminae has been controversial (Baraud 1992) because Peritryssus presents an antennal club of three segments $\left(2^{0}\right)$ in contrast to the five to seven-jointed club of the rest of genera $\left(2^{1-3}\right)$. Our analysis reveals that the remarkable Peritryssus is indeed a Pachydeminae that is defined by one synapomorphy: anal wing vein AA1 +2 reduced to a sinus $\left(31^{1}\right)$, and two derived features in the genitalia: an 'Y-shaped' spiculum gastrale with a robust vertical branch $\left(34^{2}\right)$, shared with Ceramida, and a strongly asymmetrical phallobase $\left(38^{1}\right)$, also present in Phobetus, Atanyproctus, Ceramida and Elaphocera.

(3) Pachydema: This genus appears to be monophyletic, except for the position of Pachydema zhora, which is placed in the second clade, and $P$. rubripennis, located in a polytomy with Hemictenius and the rest of Pachydema species (Fig. 81). As mentioned above, the classification of $P$. zhora was problematic because this species differs considerably from the 


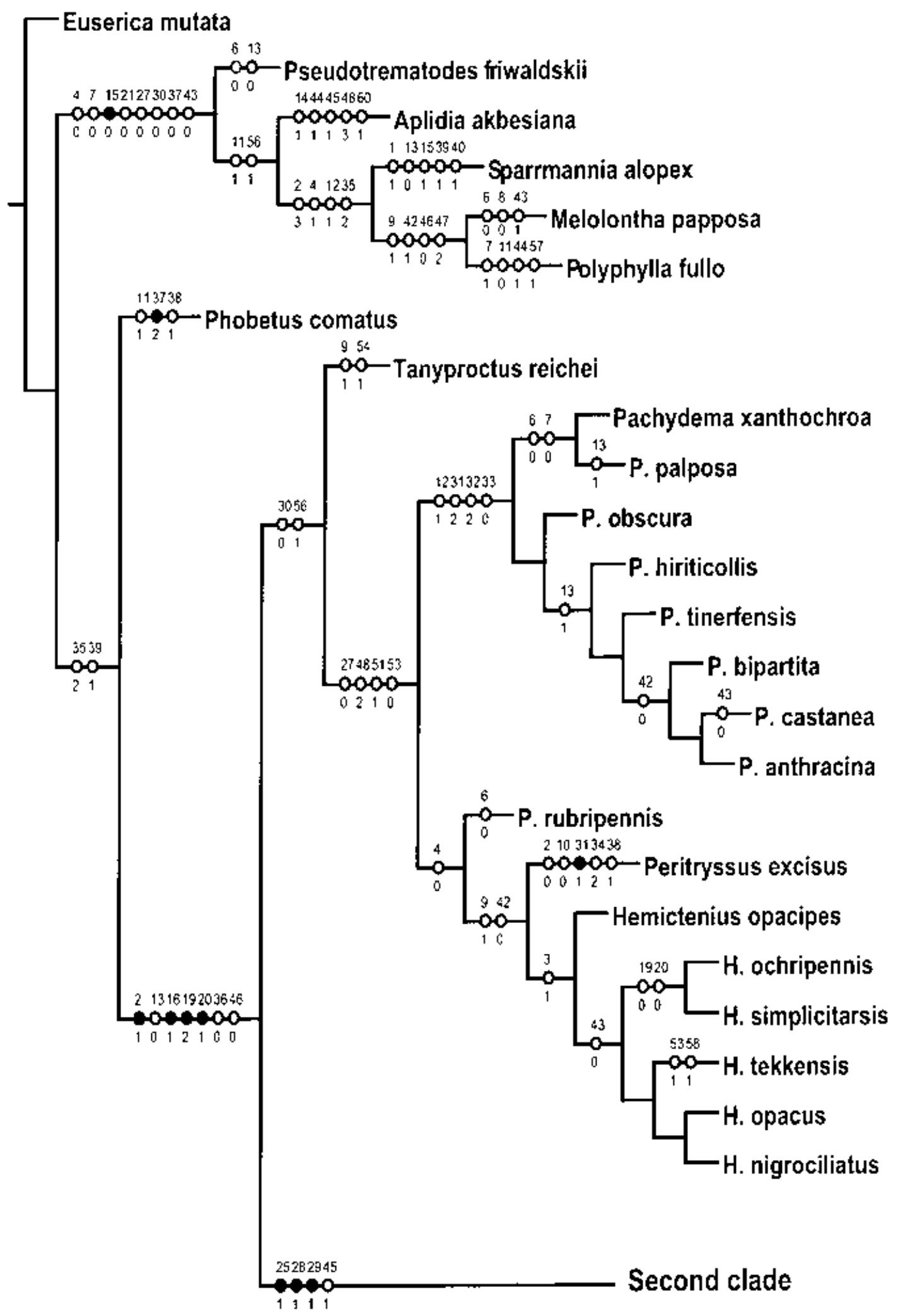

Fig. 82. One of the 32 MPTs. Characters mapped under the 'unambiguous characters only' option, using WINCLADA vs. 0.9.9 (Nixon 2000). Black circles indicate uniquely derived features, empty circles indicate characters that either reverse or evolved at least twice on the tree. The top figure on each character circle gives the character number of Table 2, whereas the bottom figure gives the character state

groundplan morphology of Pachydema on both external characters $\left(1^{1}, 4^{0}, 7^{1}, 12^{0}\right)$, mouthparts $\left(27^{1}-30^{1}\right)$, wing anatomy $\left(31^{0}, 32^{\circ}\right)$, and genitalia $\left(42^{2}, 43^{\circ}\right)$. Pachydema rubripennis, on the other hand, differs from the other species of Pachydema in that it presents for some characters of the external morphology $\left(4^{0}, 6^{0}, 12^{0}\right)$ and the wing anatomy 


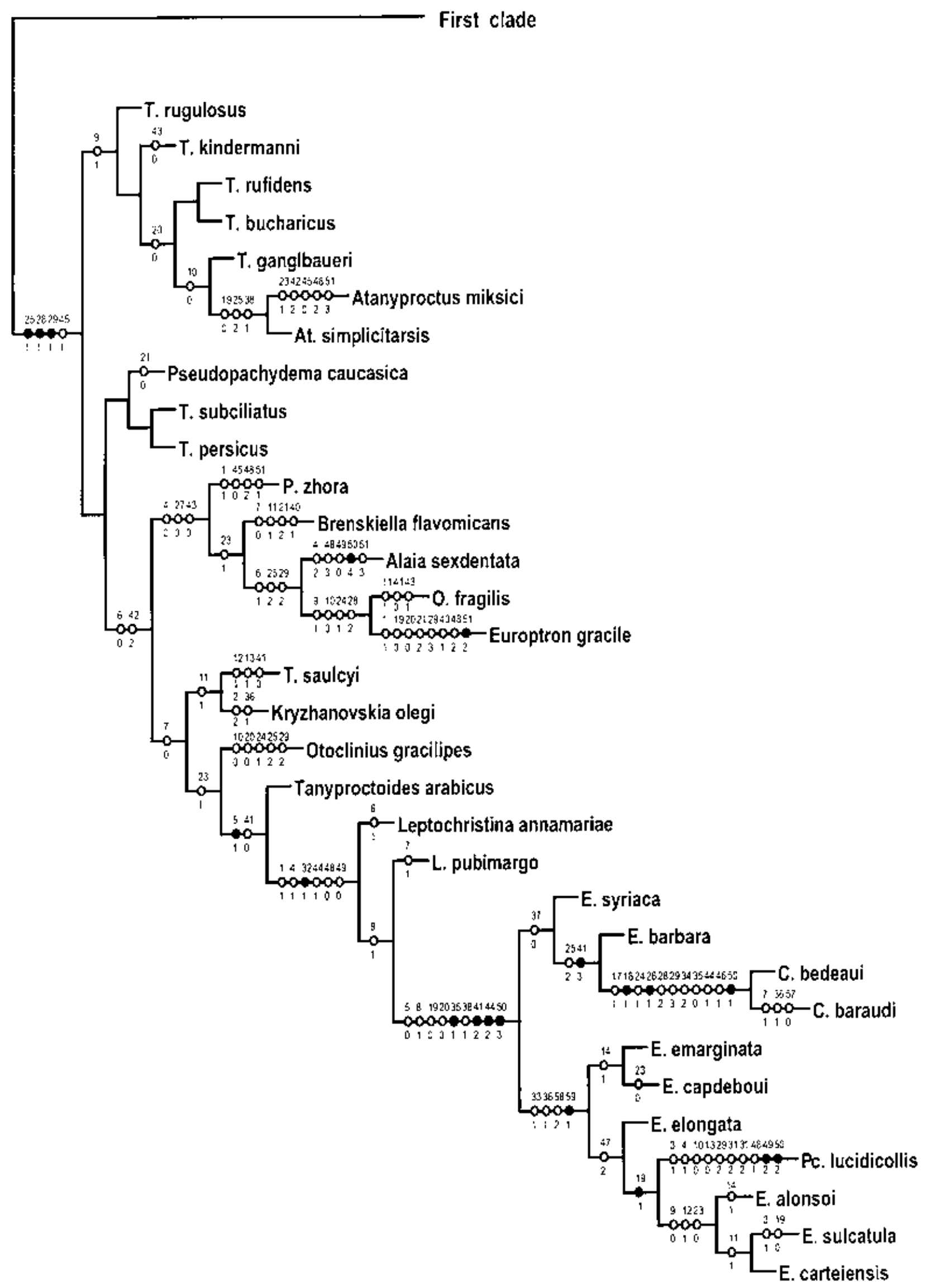



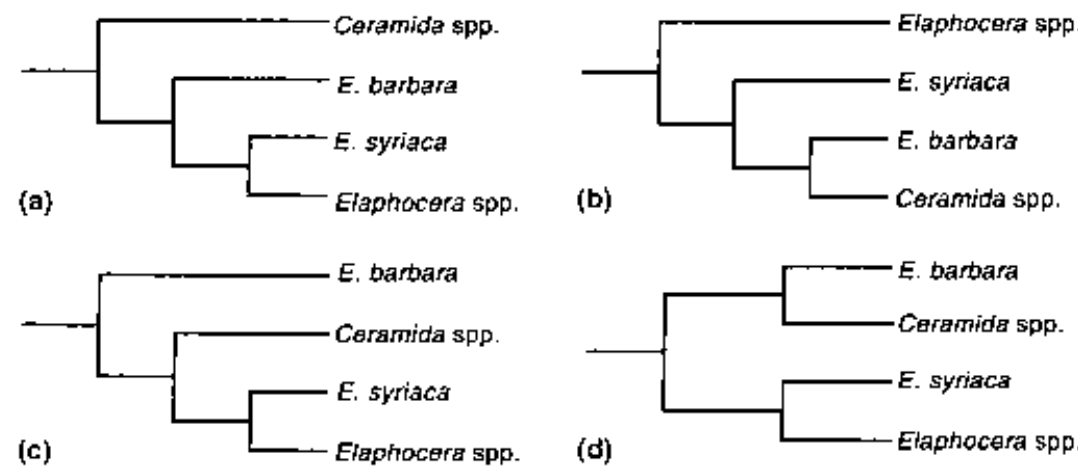

Fig. 83. Alternative arrangements of Elaphocera barbara and E. syriaca on the MPTs in relation to Elaphocera and Ceramida

$\left(31^{0}-32^{0}\right)$ the same state as Melolonthinae, instead of the more derived state present in the rest of species.

Pachydema shares the same state with Hemictenius and the Melolonthinae for most mouthpart $\left(23^{0}-30^{\circ}\right)$ and genitalic characters $\left(36^{0}, 38^{0}, 40^{0}, 44^{0}-47^{0}, 50^{\circ}\right)$. The monophyly of Pachydema is supported by four character states: $12^{1}, 31^{2}-32^{2}-33^{0}$ (Fig. 82). The shape of the last segment of the antennal funicle, short and applied to the club $\left(4^{2}\right)$, has traditionally been used to separate Pachydema from the rest of genera (Baraud 1992) but it is not a good character because the segment is also applied to the club in Tanyproctus. The genus should instead be re-diagnosed based on the following character states: polygonal clypeus $\left(1^{0}\right)$, antennal club with five segments $\left(2^{1}\right)$, enlarged tarsal joints $\left(20^{1}\right)$ entirely covered with a brush of small setae $\left(19^{2}\right)$, well-developed mouthparts $\left(23^{0}-30^{0}\right)$, male wings with anterior anal vein AA1 +2 absent $\left(31^{2}\right)$ and anal region deeply sinuated $\left(32^{2}\right)$, fully winged females $\left(33^{0}\right)$, endophallus with a terminal diverticle $\left(44^{0}\right)$ and divided into three sensilliferous areas $\left(48^{2}\right)$, medial area of endophallus armed with sclerotized structures $\left(45^{\circ}\right)$ and raspulae $\left(51^{1}\right)$, spermatheca narrow throughout $\left(58^{\circ}\right)$ and with a short conduct $\left(56^{1}\right)$, and spermathecal gland inserted at the end of the spemathecal conduct $\left(57^{0}\right)$.

Within the genus, Pachydema xanthochroa Fairmaire, 1879 and $P$. palposa are sister-species, supported by the presence of pubescence on clypeus and frons $\left(6^{0}, 7^{0}\right)$, whereas the clade $P$. castanea $-P$. bipartita $-P$. anthracina is supported by the sharp apex of parameres $\left(42^{0}\right)$. The phylogeny rejects the traditional classification of Pachydema into subgenera, according to which $P$. rubripennis, $P$. zhora and $P$. anthracina belong to the subgenus Artia, whereas $P$. hirticollis and $P$. xanthochroa belong to Pachydema s. str., and P. palposa to Sparophysa (Baraud 1985). The monophyly of the Canarian species is also rejected, as $P$. castanea and P. bipartita are more closely related to the African $P$. anthracina than to the Canarian P. obscura (Brullé, 1838) and P. tinerfensis Galante \& Stebnicka, 1992. This suggests a multiple origin of the Canarian species from different African lineages, instead of a radiation from a common ancestor (Thorpe et al. 1993). Because the Canary islands are volcanic and were probably never connected with each other or the African continent (Anguita and Hernán 1975; Juan et al. 1995), dispersal is the most likely explanation for the colonization of the archipelago. This is further supported by the fact that Pachydema is the only known genus of Palearctic Pachydeminae where females are fully winged.
(4) Hemictenius: This genus appears as monophyletic (Fig. 81) but the monophyly is only supported by one character change (Fig. 82): the first segment of the antennal club half the length of the others $\left(3^{1}\right)$, which has been used in the genus diagnosis (Baraud 1992). However, Hemictenius should also be diagnosed based on the following character states (some of them shared with Pachydema): antennal club of five segments $\left(2^{1}\right)$, last segment of funicle short and cup-shaped $\left(4^{0}\right)$, well-developed mouthparts $\left(23^{0}-30^{0}\right)$, male wings complete $\left(31^{0}-32^{0}\right)$, females with vestigial wings $\left(33^{3}\right)$, sharp apex of parameres $\left(42^{0}\right)$, endophallus terminally diverticled $\left(44^{0}\right)$, divided into three sensilliferous areas $\left(48^{2}\right)$, and armed with sclerotized structures $\left(45^{0}\right)$ and raspulae $\left(51^{1}\right)$, short spermathecal conduct $\left(56^{1}\right)$, spermathecal gland inserted at the base of the spermathecal conduct $\left(57^{1}\right)$, and pouch of spermatheca 'barrel-shaped' $\left(58^{2}\right)$. Within the genus, H. ochripennis Reitter, 1902 and H. simplicitarsis Reitter, 1897 form a monophyletic group defined by the absence of a setal brush on the tarsal joints $\left(19^{0}\right)$ and the cylindrical shape of the joints $\left(20^{\circ}\right)$. This is in agreement with current identification keys for Hemictenius (Nikolajev 1987) in which both tarsal characters are used to separate a basal group of species $(H$. ochripennis, H. simplicitarsis and $H$. comatus Nikolajev, 1975) from the rest. Nikolajev (2000) included Hemictenius tekkensis within the new genus Asiactenius. The phylogeny nests $H$. tekkensis within Hemictenius as sister-group to $H$. nigrociliatus Reitter, 1897 and H. opacus (Ball., 1870). Given that Asiactenius differs from Hemictenius by only one character (basal enlargement of the male meso- and metatarsal claws), Asiactenius could simply be a subgenus of Hemictenius or another internal basal group, such as $H$. ochripennis $-H$. comatus $-H$. simplicitarsis

(5) Tanyproctus: This genus can be rejected as polyphyletic. Apart from T. reichei, T. saulcyi is included into a different clade than the rest, whereas T. ganglbaueri (Brenske, 1897) is grouped with two species of Atanyproctus, A. miksici and A. simplicitarsis, and the rest of the genus is not resolved. This result is not unexpected because Tanyproctus as a genus is not supported by a single synapomorphy. The genus has traditionally been defined by a five jointed-antennal club with the last segment of funicle long and nonapplied to the club (Baraud 1992). However, as mentioned above, this is not a good diagnostic character, first, because the last funicular segment is actually applied to the club in Tanyproctus $\left(4^{2}\right)$, the length varying among species, and, second, because this condition is shared with the species of Pachydema. The rest of character states shared by the species of Tanyproctus are all present in other genera (symplesiomorphic). 
The phylogeny apparently supports the monophyly of Atanyproctus (Fig. 81). This genus differs from Tanyproctus by the absence of a brush of setae on the tarsal joints $\left(19^{0}\right)$ (Baraud 1992) but this analysis points out two more derived features: epipharynx with very reduced areas of setae $\left(25^{2}\right)$ and phallobase with an asymmetrical basal ostium $\left(38^{1}\right)$. However, as shown in Fig. 82, A. miksici differs from A. simplicitarsis in numerous characters of the male genitalia $\left(42^{2}, 45^{0}, 48^{2}, 51^{3}\right)$, and the same differences have been observed between A. ernae Petrovitz, 1980 and A. afghanus Petrovitz, 1968 (see Appendix).

(6) The phylogeny recognizes the existence of a new clade comprising Pachydema zhora, Europtron gracile Marseul 1867, Otoclinius fragilis and the monospecific genera, Brenskiella and Alaia (Fig. 81). Three character states diagnose this new group (Fig. 82): antennal funicle short and cup-shaped ( $\left.4^{0}\right)$, distinct sensorial area in the last segment of maxillary palp $\left(27^{\circ}\right)$, and apex of parameres without lateral process $\left(43^{0}\right)$. Yet, as indicated by the long branches, species of this group differ considerably from each other. Up to eight character states separates Europtron gracile from Otoclinius fragilis, whereas their sister-group relationship is supported by four states, two of them related to the mouthparts: a tongue-shaped labrum $\left(24^{1}\right)$ and a very reduced galea $\left(28^{2}\right)$.

According to this new grouping, the genus Otoclinius is not monophyletic, with $O$. gracilipes Brenske 1896 and $O$. fragilis Petrovitz, 1980 in different clades (Fig. 81). It also rejects Baraud (1992)'s suggestion that Otoclinius should be included within Pachydema. Otoclinius comprises five Iranian species: O. gracilipes, O. fragilis, O. schauffelei Petrovitz, 1958, O. richteri Petrovitz, 1958, and O. loebli Baraud, 1991 (Baraud 1991). The species are characterized by an orangish coloration, very short clypeus and long tarsus. These similarities, however, may be convergences because $O$. gracilipes and $O$. fragilis differ in numerous diagnostic characters $\left(4^{0,2}, 6^{0,1}, 7^{0,1}, 9^{0,1}, 11^{0,1}\right.$, $\left.20^{0,1}, 27^{0,1}, 28^{1,2}, 41^{0,1}\right)$, and the same differences have been observed between the other two species studied, O. loebli and $O$. schauffelei (Appendix). Indeed, the study of the type material shows that $O$. shauffele $i$ and $O$. loebli are identical to $O$. fragilis and $O$. gracilipes, respectively, for all characters here analysed so we propose the synonymy of these species (see Discussion).

(7) Leptochristina: This genus is the sister-group to the Mediterranean genera Ceramida, Elaphocera, and Pachydemocera (Fig. 81). The grouping is supported by one synapomorphy (Fig. 82): wing anal region in males slightly sinuated $\left(32^{1}\right)$ and five character changes: a rounded clypeus $\left(1^{1}\right)$, antennal funicle long and stick-shaped $\left(4^{1}\right)$, and simple endophallous $\left(44^{1}\right)$ with only a medial area of sensilla $\left(48^{0}\right)$ and distal area absent $\left(49^{0}\right)$. They also share a seven-jointed antennae $\left(2^{3}\right)$. Tanyproctoides arabicus is the sister group to this clade, sharing with Leptochristina the last segment of funicle inserted far from the base of the club $\left(5^{1}\right)$ and the straight profile of parameres $\left(41^{0}\right)$.

Relationships within Leptochristina are not resolved in the consensus (Fig. 81) so the genus can be either para- or monophyletic. Leptochristina pubimargo Reitter, 1902 and L. annamariae Baraud and Branco, 1991 differ on the pubescence of the clypeus $\left(6^{0,1}\right)$, frons $\left(7^{0,1}\right)$ and anterior margin of pronotum $\left(9^{0,1}\right)$, and on the presence of a ridge on the posterior margin of pronotum $\left(13^{0,1}\right)$. Yet, the genitalia, mouthparts and wing anatomy are similar in both species.
(8) Elaphocera: The sister-group relationship between the three Mediterranean genera, Ceramida, Elaphocera and Pachydemocera, is the best supported in the phylogeny. Up to nine character state changes, four of them true synapomorphies, supports this relationship: last funicular segment near the base of the club $\left(5^{0}\right)$, inner margin of clypeus pubescent $\left(8^{1}\right)$, tarsal joints with a brush of setae $\left(19^{\circ}\right)$ and cylindrical $\left(20^{\circ}\right)$, vestigial sternite of genital segment reduced $\left(35^{1}\right)$, and an asymmetrical basal ostium $\left(38^{1}\right)$, profile of parameres sickle-shaped or elbowed near the middle $\left(41^{2-3}\right)$, endophallus with a secondary sac attached to temones $\left(44^{2}\right)$, and medial area of endophallus covered with numerous types of sensilla $\left(50^{3}\right)$.

The monophyly of Elaphocera is not clear from the analysis. The strict consensus shows E. barbara and E. syriaca in a tetratomy with Ceramida and the remaining species of Elaphocera (Fig. 81). Figure 83 shows the four possible positions of these two species on the MPTs in relation to Elaphocera and Ceramida. In general, Elaphocera barbara is placed closer to Ceramida than E. syriaca. Furthermore, an unpublished analysis including all species of Elaphocera and Ceramida showed the same grouping as Fig. 83d, with E. barbara as sister-group to Ceramida, and E. syriaca as the most basal species of Elaphocera. Indeed, E. syriaca is placed in this position in 27 out of 32 MPTs. Elaphocera barbara has traditionally been included within Elaphocera on the basis of two diagnostic characters (Baraud 1992): inner spine of fore tibiae behind the second outer tooth $\left(17^{0}\right)$ and first joint of hind tarsus equal to the second $\left(18^{0}\right)$. These character states, however, are present in most genera of Pachydeminae (symplesiomorphies). In contrast, E. barbara shares the same state as Ceramida for several characters: non-pointed metacoxae $\left(14^{0}\right)$, areas of setae in epipharynx very reduced $\left(25^{2}\right)$, long parameres relative to phallobase $\left(36^{0}\right)$, weak dorsal strangulation in phallobase $\left(37^{0}\right)$, parameres elbowed near the middle $\left(41^{3}\right)$, and ' $\mathrm{V}$ '-shaped piece only one third of the length of temones $\left(47^{0}\right)$. Elaphocera syriaca presents the same state as Ceramida for three of these characters $\left(14^{0}, 36^{0}, 37^{0}\right)$.

Excluding E. barbara and E. syriaca, Elaphocera is a monophyletic genus defined by three character states (Fig. 82): brachypterous females $\left(33^{1}\right)$, parameres shorter than phallobase $\left(36^{1}\right)$, pouch of spermatheca 'barrel'-shaped $\left(58^{2}\right)$, and one synapomorphy, spheric spermathecal gland $\left(59^{1}\right)$. The species of Elaphocera are also characterized by a phallobase with a strong dorsal strangulation $\left(37^{1}\right)$, elongated ' $V$ ' shapedpiece $\left(47^{1,2}\right)$, and female accessory gland I covered with basiconic setae $\left(61^{1}\right)$.

(9) Pachydemocera: The phylogeny clusters the only species of this genus, Pachydemocera lucidicollis (Kraatz, 1882), within Elaphocera (Fig. 81) so the generic status of Pachydemocera should be revised (see Discussion). In addition to the derived features above mentioned, Pachydemocera shares with Elaphocera a large number of morphological features: slightly developed mouthparts $\left(25^{1}-28^{1}, 30^{0}\right)$, vestigial sternite of the genital segment not entirely developed $\left(35^{1}\right)$, phallobase with an asymmetrical basal ostium $\left(38^{1}\right)$, and endophallus with a secondary sac $\left(44^{2}\right)$. Baraud (1992) distinguished Pachydemocera from Elaphocera by the first segment of the antennal club half the length of the rest $\left(3^{1}\right)$, but this condition is also present in the North African species Elaphocera sulcatula. Furthermore, the external morphology of Pachydemocera lucidicollis is strikingly similar to that of the eastern Mediterranean species of Elaphocera. Indeed, Kraatz (1882) originally described Pachydemocera lucidicollis as Elaphocera lucidicollis. Reitter 
(1902) subsequently erected the new genus Pachydemocera for this species and included two new species, $P$. pubimargo and $P$. pubicavula. Petrovitz (1962) described a fourth species, Pachydemocera variabilis. Finally, Baraud and Branco (1991) divided Pachydemocera into two different genera: Pachydemocera s. str. Reitter, 1902 comprising P. lucidicollis, and the new genus Leptochristina Baraud and Branco, 1991; comprising L. pubimargo, L. pubicavula, L. variabilis, and a new species, L. annamariae. Although our analysis indicates that Baraud and Branco's division was right, they failed to notice the resemblance between Pachydemocera and Elaphocera. The same characters employed to separate Pachydemocera from Leptochristina indicate the identity between Pachydemocera and Elaphocera.

(10) Ceramida: The monophyly of this genus is the best supported in the phylogeny (Fig. 82). Ceramida is diagnosed by up to 11 character-state changes, three of them true synapomorphies. The genus should be re-diagnosed by the following characters: inner spine of fore tibiae ahead or in front of second outer tooth $\left(17^{1}\right)$, first segment of hind tarsus distinctly longer than the second $\left(18^{1}\right)$, tongue-shaped labrum $\left(24^{1}\right)$, areas of setae in epipharynx very reduced $\left(25^{2}\right)$, last segment of maxillary palp elongated and stick-shaped $\left(26^{1}\right)$, galea unarmed and very reduced $\left(28^{2}\right)$, reduced mandibles with a sharp scissorial area $\left(29^{3}\right)$, females with vestigial wings $\left(33^{3}\right)$, Y-shaped spiculum gastrale with a long robust vertical branch $\left(34^{2}\right)$, reduced vestigial sternite $\left(35^{0}\right)$, simple endophallus $\left(44^{1}\right)$, $\mathrm{V}$-shaped piece not reaching temones $\left(46^{1}\right)$, medial area of endophallus covered with trichoid and finger-shaped sensilla $\left(50^{1}\right)$, female accessory gland I more than three times the size of accessory gland II $\left(60^{1}\right)$, and accessory gland II covered with rhombus-shaped plaques $\left(62^{1}\right)$.

\section{Discussion}

It would be premature to translate the phylogeny presented here into a new classification of the Palearctic Pachydeminae because some groups are weakly supported and a more complete set of female characters would be desirable. However, several conclusions can be drawn from the analysis that concern the relationships among genera and their monophyly. The Palearctic Pachydeminae are monophyletic with respect to the Melolonthinae and form a monophyletic group within the entire subfamily, although the latter should be re-evaluated using other non-Palearctic genera. The phylogeny shows that most characters from the male external morphology that have been used in the diagnosis of the genera are either plesiomorphic or highly homoplastic, e.g. the shape of the last funicular segment or the enlargement of the male tarsal joints. Instead, characters from the mouthparts, wing anatomy and genitalia are far more conservative and therefore provide better synapomorphies for the definition of genera and their relationships.

Peritryssus is confirmed as a Pachydeminae and it is placed as the sister-group to Hemictenius. This remarkable genus presents some unique characters (e.g. three-jointed antennal clubs, anal wing AA1 +2 reduced to a sinus, asymmetrical phallobase), some of them shared with other non-Palearctic genera. The monophyly of some of the largest genera, such as Hemictenius and Ceramida, is demonstrated although their current diagnosis is based on plesiomorphic characters. They should instead be re-diagnosed on the basis of the new characters studied here, mainly from the mouthparts and genitalia. Apart from $P$. zhora and P. rubripennis, the phylogeny supports the monophyly of Pachydema but rejects the traditional division into species-groups and the monophyly of the endemic Canarian species. Elaphocera is also monophyletic if E. barbara is excluded, this species presenting the same state as Ceramida for many mouthpart and genitalic characters. Tanyproctus can be rejected as polyphyletic because, even though new species could be added to the analysis, it is unlikely that they would render the genus monophyletic. This is not surprising since the diagnosis of Tanyproctus was based on symplesiomorphies. Leptochristina is either mono- or paraphyletic, being the sister-group to the three Mediterranean genera Ceramida, Elaphocera and Pachydemocera. A sister-group relationship between these three genera is the best supported by the data set.

This study also highlights the question of whether the smallest genera of Pachydeminae are necessary from a phylogenetic viewpoint. The position of Kryzhanovskia and Pseudopachydema could not be resolved, whereas Atanyproctus is grouped with some species of Tanyproctus in the cladrogram. The monotypic Alaia and Brenskiella could be merged into one genus with Europtron (together with Pachydema zhora and Otoclinius fragilis) but the grouping should be confirmed by the inclusion of the other two species of Europtron (E. confusum Marseul, 1878 and E. atlanticum Bezdek et al., 1999). Otoclinius is probably polyphyletic but we would need to study O. ritchteri to confirm it. However, Baraud (1992)'s suggestion that Otoclinus should be included within Pachydema is rejected by the phylogeny.

Based on the set of characters here analysed, we propose the synonymy of the following species of Otoclinius:

Otoclinius shauffelei Petrovitz, 1958 (Stutt. Beitr. Naturk. 8, 5-7)

= Otoclinius fragilis Petrovitz, 1980 (Ann. Naturhist. Mus. Wien 83, 629-631 syn. nov.)

Otoclinius gracilipes Brenske, 1896 (Berliner Entom. Zeitsch. 41, 320-322)

$=$ Otoclinius loebli Braud, 1991 (Archs. Sci. Genéve 44, 289-291 syn. nov.)

Finally, the phylogeny nests the monotypic Pachydemocera within Elaphocera so we propose here the following junior synonym:

Elaphocera Gené, 1836. (Ann. Soc. Entomol. Fr., 5, Bull. (1): (III)

= Pachydemocera Reitter, 1902. (Best. Tab., 50: 105 syn. nov.)

Elaphocera lucidicollis Kraatz, 1882. (Deuts. Ent. Zeitschr., 26, 31)

= Pachydemocera lucidicollis Kraatz, 1882. (Reitter 1902. Best. Tab., 50: 106)

\section{Acknowledgements}

We thank Juan. J. Morrone, Henrik Enghoff, Marc Lacroix and an anonymous reviewer for their helpful comments to the paper. For the loan of material we are greatly indebted to the following persons and institutions: J. Krikken (National Museum of Natural History, Leiden), Cl. Girard (Muséum Nationale d'Histoire Naturelle, Paris), P. Perkins (Museum of Comparative Zoology, Harvard University, Cambridge, MA), O. Merkl (Hungarian Natural History Museum, Budapest), M. Uhlig (Museum fur Naturkunde der Humboldt Universität, Berlin), D. Kovac (Forschungsinstitut und Naturmuseum Senckenberg, Frankfurt), L. Zerche (Deutsches Entomologisches Institut, Eberswalde), B. Brugge (University of Amsterdam), I. Löbl 
(Museum of Natural History, Genéve), D. Furth (Smithsonian Institution, Washington), L. Hermann (American Museum of Natural History, New York), A. Ferreira (Museu e Laboratorio Zoologico da Faculdade de Ciencias, Universidade de Coimbra). We are especially grateful to Artur Serrano (Universidade de Lisboa), José Luis Ruiz, Pablo Bercedo and, particularly, to José Ignacio López Colón, for the loan of specimens from their private collections. We would also like to thank Emilio Soteras for his beautiful drawings and to José Bedoya for his help with the SEM facilities. This work was supported by the Project Fauna Ibérica: PB92-0121- DGICYT, PB95-0235-DGICYT, and a Marie Curie Fellowship (Project MCFI-2000-00794).

\section{Zusammenfassung}

Erste phylogenetische Analyse der Subfamilie Pachydeminae (Coleoptera, Scarabaeoidea, Melolonthidae): Die paläarktischen Pachydeminae

Diese Arbeit enthält die erste phylogenetische analyse der Pachydeminae Reitter 1902, einer der am wenigsten bekannten Subfamilie der Melolonthidae (Blattkäfer - Scarabaeoidea, Coleoptera). Einige Arten der Pachydeminae haben sich in Südspanien in der letzten Zeit zu landwirtschaftlichen Schädlingen entwickelt. Wir haben die phylogenetischen Beziehungen von 49 Arten aus der paläarktischen Region anhand von 63 morphologischen Merkmalen der externen Morphologie, der Flügelanatomie, der Mundwerkzeuge und der männlichen und weiblichen Genitalia der adulten Tiere analysiert. Die letzten drei genannten Merkmale werden hier das erste Mal beschrieben. Die phylogenetische analyse zeigt, daß die palaärktischen Pachydeminae innerhalb der Unterfamilie monophyletisch sind. Die Munkwerkzeuge und die männlichen und weiblichen Genitalia ergeben die besten Synapomorphien zur Beurteilung der Beziehungen zwischen den Gattungen. Im Gegensatz dazu sind die meisten der in der Taxonomie der Pachydeminae benutzten externen morphologischen Merkmale stark homoplastisch. Die Phylogenie zeigt eine basale Aufspaltung zwischen den Gattungen Hemictenius Reitter 1897, Pachydema Castelnau 1832 und der monospecifischen Gattung Peritryssus Reitter 1918 und einer zweiten Clade, die den Rest der Gattungen enthält. Es ist erwähnenswert, daß die Zugehörigkeit von Peritryssus zu den Pachydeminae als Schwestergruppe zur monophyletischen Gattung Hemictenius bestätigt wird. Mit Ausnahme der Stellung von $P$. rupripennis (Lucas, 1848), und $P$. zhora Normand, 1951, unterstützt die phylogenetische Analyse die Monophylie von Pachydema, verwirft aber die traditionelle Einteilung die Artengruppen und die Monophylie der auf den Kanaren endemischen Arten. Die Gattung Tanyproctus Faldermann, 1835, muß hingegen als polyphyletisch abgelehnt werden. Wahrscheinlich ist auch Octoclinius Brenske, 1896, polyphyletische (zwei synonyme Arten), während Leptochristina Baraud \& Branco, 1891, entweder mono- oder paraphyletisch sind. Die beiden mediterranen Gattungen Ceramida Baraud, 1897, und Elaphocera Gené, 1836, bilden eine monophyletische Gruppe, was von den Daten her die beste Unterstützung erfährt Ceramida ist eindeutig monophyletisch, während Elaphocera mit Ausnahme von E. barbara Rambur, 1843, welche mit den Arten der Gattung Ceramida in der Charakterausprägung zahlreicher merkmale der Mundwerkzeuge und der Genitalia Gemeinsamkeiten aufweist, wahrscheinlich monophyletisch ist. Die phylogenetische Analyse stellt die kleinen, monophyletischen Gattungen der Pachydeminae in Frage. Die monotypischen Gattungen Alaia Petrovitz, 1980, und Brenskiella Berg, 1898, sind mit Europtron Marseul, 1867, in einer Clade vereint, während Atanyproctus Petrovitz, 1954, zusammen mit einigen Arten von Tanyproctus, und der monotypischen Gattung Pachydemocera Reitter, 1902, zusammen gruppiert werden, wobei Elaphocera als neues Synonym vorgeschlagen wird.

\section{References}

Alvarado, M.; Serrano, A.; Durán, J. M.; De la Rosa, A., 1996: Problemática de los gusanos blancos (Coleoptera, Scarabaeidae) en el olivar de la provincia de Sevilla. Bol. San. Veg. Plagas 22, 319-328. Anguita, F.; Hernán, F., 1975: A propagating fracture model versus a hot spot origin for the Canary Islands. Earth Planet Sci., Lett. 27, 11-19.
Arnqvist, G., 1998: Comparative evidence for the evolution of genitalia by sexual selection. Nature 393, 784-786.

Arrow, G. J., 1932: A few new species of Melolonthinae Coleoptera (XXVII). Ann. Mag. Natural History 9, 189-197.

Balachowsky, A. S., 1962: Entomologie Appliquée À l'Agriculture, 1. Coléoptères. Paris, France: Masson et Cie. pp. 1-564.

Baraud, J., 1985: Coléoptères Scarabaeoidea. Faune du Nord de l'Afrique: du Maroc au Sinaï. Editions Lechevalier, Encyclopédie Entomologique XLVI. Paris, France: Ed. Lechevalier. pp. 1-651.

Baraud, J., 1991: Otoclinius loebli, nouvelle espèce d'Iran. (Coleoptera, Melolonthidae, Pacchydeminae). Archs. Sci. Genève 44, 289-291.

Baraud, J., 1992: Coléoptères Scarabaeoidea d'Europe. Faune de France et régions limitrophes no. 78. Lyon, France: Ed. Société Linnéenne de Lyon et Fédération Francaise des Sociétés de Sciences Naturelles, pp. 1-850.

Baraud, J., 1994: Coléoptères Scarabaeoidea des archipels atlantiques: Azores, Canaries et Medère (2ème partie). Bulletin mensuel de la Société Linnéenne Lyon 63, 73-96.

Baraud, J.; Branco, T., 1991: Scission du genre Pachydemocera Reitter, 1902 (Coleoptera Melolonthidae Pachydeminae). Bull. Société Entomologique France 96, 175-181.

Bezdek, A.; Král, D.; Keith, D.; Lacroix, M., 1999: Revision of the genus Europtron with description of Europtron atlanticum sp. n. from Morocco (Coleoptera: Scarabaeidae: Melolonthinae). Acta Societatis Zool. Bohemoslovenicae 63, 395-406.

Branco, T., 1981: Contribution à la connaisance des Elaphocera Gené ibériques: quatre nouvelles espèces du Portugal (Col., Scarabaeoidea, Melolonthidae). Bull. Société Entomologique France 86, 124-144.

Browne, D. J.; Scholtz, C. H., 1994: The morphology and terminology of the hindwing articulation and wing base of the Coleoptera, with specific reference to the Scarabaeoidea. Syst. Entomol. 19, 133-143.

Browne, D. J.; Scholtz, C. H., 1995: Phylogeny of the families of Scarabaeoidea (Coleoptera) based on characters of the hindwing articulation, hindwing base and wing venation. Syst. Entomol. 20, 145-173.

Browne, D. J.; Scholtz, C. H., 1998: Evolution of the scarab hindwing articulation and wing base: a contribution toward the phylogeny of the Scarabaeidae (Scarabaeoidea, Coleoptera). Syst. Entomol. 23, 307-326.

Clark, C.; Curran, D. J., 1986: Outgroup analysis, homoplasy, and global parsimony: a response to Maddison, Donoghue and Maddison. Syst. Zool. 35, 422-426.

Coca-Abia, M., 1995: Taxonomía, Filogenia y Biogeografía del género. Rhizotrogus (Col. Melolonthidae) en el Mediterráneo occidental. Unpublished Ph D Thesis. Madrid, Spain: Universidad Complutense de Madrid.

Coca-Abia, M.; Martín-Piera, F., 1991: Anatomy and morphology of the genitalia in the subtribe Rhizotrogina (Col. Melolonthidae, Melolonthini): taxonomic implications. In: Zunino, M.; Bellés, X.; Blas, M. (eds), Advances in Coleopterology. Barcelona, Spain: Ed. Association European Coleopterology, pp. 61-78.

Decelle, J. E., 1982: Missioni 1962 e 1965 del Prof. Giuseppe Scortecci nell'Arabia meridionale-Melolonthinae. Atti della Societá Italiana Scienze Naturali 123, 375-387.

Dufour, L., 1844: Anatomie Generale des Diptères. Ann. Sci. Nat. 1, 244-264.

Eberhard, W. G., 1985: Sexual Selection and Animal Genitalia. Cambridge, MA: Harvard University Press.

Eberhard, W. G., 1991: Copulatory courtship and cryptic female choice in insects. Biol. Rev. 66, 1-31.

Eberhard, W. G., 1992: Species isolation, genital mechanics, and the evolution of species-specific genitalia in three species of Macrodactylus beetlees (Coleoptera, Scarabaeidae, Melolonthinae). Evolution 46, 1774-1783.

Eberhard, W. G., 1993: Copulatory courtship and morphology of genitalic coupling in seven Phyllophaga species (Coleoptera: Melolonthidae). J. Nat. Hist. 27, 683-717.

Farris, J. S., 1970: Methods for computing Wagner trees. Syst. Zool. 19, 83-92.

Feliú-Badaló, E.; Vilaplana, L.; Bellés, X., 1996: Morphology and protein pattern of the accessory reproductive glands of male Blatella germanica (Dyctyoptera: Blatellidae). Eur. J. Ent. 93, 211-221. 
Fitch, W. H., 1971: Toward defining the course of evolution: minimum change for a specified tree topology. Syst. Zool. 20, 406-416.

Goloboff, P., 1998: NONA. Computer program and software. Tucuman, Argentina: Published by the Author.

Gwynne, D. T., 1998: Genitally does it. Nature 393, 734-735.

Harshman, L. G., 1996: A molecular basis for sperm competition in Drosophila melanogaster. In: Bologna, M.; Zilli, A. (eds), Proceedings of the XX International Congress of Entomology. Societá Entomologica Italiana, Firenze, Italy, p. 368.

Hieke, F., 1966: Vergleichende funktionelle Anatomie der Abdominalmuskulatur einiger mannlicher Coleopteren unter besondere berucksichtigung des genitoanal Complex. Deutsche Entomologische Z 13, 1-165.

Holloway, B. A., 1960: Taxonomy and phylogeny in the Lucanidae (Insecta: Coleoptera). Records Dominion Museum 3, 321-365.

d'Hotman, D.; Scholtz, C. H., 1990a: Phylogenetic significance of the structure of the external male genitalia in the Scarabaeoidea (Coleoptera). Entomol. Mem. Dept Agric. Dev. Report S. Afr. 77, $1-51$.

d'Hotman, D.; Scholtz, C. H., 1990b: Comparative morphology of the male genitalia of derived groups of Scarabaeoidea (Coleoptera). Elytron 4, 3-39.

Howden, H. F., 1982: Larval and adults characters of Frickius Germain, its relationship to Geotrupini, and a phylogeny of some major taxa in the Scarabaeoidea (Insecta: Coleoptera). Can. J. Zool. 60, 2713-2724

Juan, C.; Oromí, P.; Godfrey, M. H., 1995: Mitochondrial DNA phylogeny and sequential colonization of Canary Islands by darkling beetles of the genus Pimelia (Tenebrionidae). Proc. R. Soc. Lond. B. 261, 173-180.

Kraatz, G., 1882: Kurze Revision der Elaphocera-Arten. Deutsche Entomologische Z 26, 17-31.

Krell, F. Th, 1996: Die Kopulationsorga ne des Maikäfers Melolontha melolontha (Insecta: Coleoptera: Scarabaeidae).- Ein Beitrag zur vergleichenden und funtionellen Anatomie der ektodermalen Genitalien ulder Coleoptera. Sttug. Beitr. Naturk. Ser. A (Biologie) 537, $1-101$.

Kukalova-Peck, J., 1983: Origin of the insect wing and wing articulation from the arthropodan leg. Can. J. Zool. 61, 1618-1669.

Kukalova-Peck, J., 1991: Fossil history and the evolution of hexapod structures. In: C.S.I.R.O. (eds), Insects of Australia, Vol. 1. Melbourne, Australia: Melbourne University Press, pp. 141-179.

Kukalova-Peck, J.; Lawrence, J. F., 1993: Evolution of the hindwing in Coleoptera. Can. Entomol. 125, 181-258.

Lacroix, M., 1993: Insectes Coléoptères: Melolonthidae (2ème partie). In: Comité de Lecture: Paulian M. R. (Président); Blanc, M. M. Ch-P.; Crosnier, A.; Dechambre, R. P.; Gutierrez, J.; Matile, L.; Petter, J. J.; Ramanantsoavisma, G.; Roederer, P.; Viette, P. (Secrétaire) (eds), Faune de Madagascar, Vol. 73. Paris, France: Muséum national d'Histoire naturelle. pp. 303-875.

Lacroix, M., 1997: Contribution à la connaissance des Pachydeminae africains I. Nouveaux genres et nouvelles espèces (Coleoptera, Scarabaeoidea, Melolonthidae). Revue fr. Ent. 19, 51-62.

Lacroix, M., 2000: Hannetons, un monde de diversité. Website: http:// hannetons.free.fr.

Lindroth, C. H.; Palmén, E., 1970: Coleoptera. In: Tuxen, S. L. (ed.), Taxonomist's Glossary of Genitalia in Insects. Copenhagen, Denmark: Munksgaard, pp. 69-76.

López-Colón, J. I., 1999: Pachydema gomerae, nueva especie de coleópteros canario (Scarabaeidae, Melolonthinae). Vieraea 27, 1-6.

Maddison, W. P., 1993: Missing data versus missing characters in phylogenetic analysis. Syst. Biol. 42, 576-581.

Maddison, W. P.; Maddison, D. R., 1992: MacClade: Analysis of phylogeny and character evolution, v. 3.0. Sunderland, MA, USA: Sinauer.

Martínez, A., 1958: Notas Coleopterologicas VIII. An. Soc. Cient. Argent. 166, 100-109.

Martínez, A., 1975: Contribución al conocimiento de los Pachydemini neotropicales (Col. Scarabaeidae, Melolonthinae). Entomologische Arbeiten aus dem Museum G. Frey 26, 227-251.

Martín-Piera, F., 1992: El valor taxonómico y sistemático de la genitalia en los Scarabaeoidea (Coleoptera). Elytron 6, 233-239.
Medvedev, S. I., 1952: Fauna SSSR X/2 (Scarabaeoidea) Melolonthinae, 2. Moskwa: Biei-Bienko. Ed. Hayka Academy of Sciences of the SSSR.

Mikkola, K., 1992: Evidence for look-and-key mechanisms in the internal genitalia of the Apamea moths (Lepidoptera, Noctuidae) Syst. Entomol. 17, 145-153.

Morrone, J. J., 1997: Cladistics of the new world genera of Listroderina (Coleoptera: Curculionidae: Rhytirrhinini). Cladistics 13, 247-266.

Nel, A.; Scholtz, C. H., 1990: Comparative morphology of the mouthparts of adult Scarabaeoidea (Coleoptera). Entomol Mem. Department Agric. Dev. Report S. Afr. 80, 1-84.

Nikolajev, G. V., 1987: Plastincatousye zuki (Coleoptera, Scarabaeoidea) kazakhstana i Srednej Azii. Scarabaeoidea (Coleoptera) of Kazakhstan and Central Asia. Nauka, Alma-Ata: Ed. Akademia Nauk Kazakhskoj SSR. pp. 1-232.

Nikolajev, G. V., 2000: A review of species of the genus Hemictenius Rtt. (Coleoptera, Scarabaeidae, Pachydeminae) with the isolation of the new genus Asiactenius. Tethys, Entomol. Res. II, 137-150.

Nikolajev, G. V.; Kabakov, O. N., 1977: New genus and new species of the Pachydeminae subfamily (Coleoptera, Scarabaeidae) from Afghanistan. Vestnik Zool. 1, 85-86.

Nixon, K. C., 1999: The parsimony Ratchet, a new method for rapid parsimony analysis. Cladistics 15, 407-414.

Nixon, K. C., 2000: WINCLADA Version Beta 0.9.9. Computer Software and Documentation. Ithaca, New York: Published by the Author.

Nixon, K. C.; Carpenter, J., 1996: On consensus, collapsibility, and clade concordance. Cladistics 12, 305-321.

Nixon, K. C.; Davis, J. I., 1991: Polymorphic taxa, missing values and cladistic analysis. Cladistics 7, 233-241.

Nordlander, G.; Zhiwei, L.; Ronquist, F., 1996: Phylogeny and historical biogeography of the cynipoid wasp family Ibaliidae (Hymenoptera). Syst. Entomol. 21, 151-166.

Oosterbroek, P.; Arntzen, J. W., 1992: Area-cladograms of circumMediterranean taxa in relation to Mediterranean palaeogeography. J. Biogeogr. 19, 3-20.

Paterson, H. E. H., 1978: More evidence against speciation by reinforcement. S. Afr. J. Sci. 74, 369-371.

Paterson, H. E. H., 1985: The recognition concept of species. In: Vrba, E. S. (ed.), Species and Speciation. Transvaal Mus. Monograph 4, Pretoria, South Africa: Transvaal Museum, pp. 21-29.

Petrovitz, R., 1962: Neue und interessante Scarabaeidae aus dem vorderen Orient, II. Reichenbachia 2, 235-267.

Petrovitz, R., 1968: Neue Tanyproctus und Atanyproctus-Arten (Pachydemini, Melolonthinae, Scarabaeidae). Entomologische Arbeiten Aus Dem Museum G Frey 19, 237-247.

Petrovitz, R., 1971: Scarabaeidae from the near East (Lamellicornia: Coleoptera). Israel. J. Entomol. 6, 215-237.

Petrovitz, R., 1980: Österreichische Entomologische Expeditionen nach Persien und Afghanistan - Beiträge zur Coleopterenfauna Teil 12 - Weiteres über Lamellicornia aus Iran. Annalen des Naturhistorischen Mus Wien 83, 597-638.

Piattella, E.; Sabatinelli, G., 1996: Una nuova specie di Tanyproctus delle Sporadi meridionale. Fragmenta Entomologica 27, 361-368

Reitter, E., 1889: Uebersicht der mir bekannten Coleopteren-Gattungen der Melolonthini mi Erichson'schen Sinne, aus der paläarctischen Fauna. Wiener Entomologische Zeitung 8, 275-279.

Reitter, E., 1902: Bestimmungs-Tabelle der Melolonthidae aus der europä Fauna und den angrenzenden Ländern, enthaltend die Grupen der Pachydemini, Sericini und Melolonthini III Teil. Verhandlungen des Naturforschenden Vereines in Brünn $\mathbf{X L}$, 93-303.

Ritcher, P. O., 1966: White grubs and their allies. A study of North American Scarabeoid larvae. Corvallis, Oregon, USA: Oregon State University Press.

Ronquist, F., 1995: Phylogeny and early evolution of the Cynipoidea (Hymenoptera). Syst. Entomol. 20, 309-335.

Sabatinelli, G.; Pontuale, G., 1998: Melolonthinae and Pachydeminae of Arabia (Coleoptera: Scarabaeoidea: Melolonthidae). Fauna Arabia 17, 107-146.

Sanderson, M. J.; Donoghue, M. J., 1989: Patterns of variation in levels of homoplasy. Evolution 43, 1781-1795. 
Sanmartín, I., 1998: Evolución de los Pachydeminae paleárticos (Col., Scarabaeoidea, Melolonthidae). Unpublished Ph. D. Thesis. Madrid, Spain: Universidad Complutense de Madrid.

Sanmartín, I.; Martín-Piera, F., 1997: Nuevos datos corológicos, fenológicos y morfológicos de Ceramida cobosi Báguena, 1955 (Coleoptera, Melolonthidae). Zool. Baetica 8, 231-233.

Sanmartín, I.; Martín-Piera, F., 1999a: Evolución de los Pachydeminae paleárticos (Coleoptera, Scarabaeoidea, Melolonthinae). Resumen de Tesis. Bol. SEA 25, 1-9.

Sanmartín, I.; Martín-Piera, F., 1999b: A morphometric approach to the taxonomy of the genus Ceramida (Coleoptera: Scarabaeoidea: Melolonthidae). Can. Entomol. 131, 573-592.

Scholtz, C. H., 1986: Phylogeny and systematics of the Trogidae (Coleoptera, Scarabaeoidea). Syst. Entomol. 11, 355-363.

Scholtz, C. H., 1990: Phylogenetic trends in the Scarabaeoidea (Coleoptera). J. Nat. Hist. 24, 1027-1066.

Scholtz, C. H.; Browne, D. J.; Kukalova-Peck, J., 1994: Glaresidae, archaeopteryx of the Scarabaeoidea (Coleoptera). Syst. Entomol. 19, 259-277.

Scholtz, C. H.; d'Hotman, D.; Evans, A. V.; Nel, A., 1988: Phylogeny and systematics of the Ochodaeidae (Coleoptera, Scarabaeoidea). J. Entomol. Soc. S. Africa 51, 207-240.

Scholtz, C. H.; d'Hotman, D.; Nel, A., 1987: Glaresidae, a new family of Scarabaeoidea (Coleoptera) to accommodate the genus Glaresis Erichson. Syst. Entomol. 12, 343-354.

Serrano, A.; Alvarado, M.; Durán, J. M.; De la Rosa, A., 1996: Contribución al conocimiento de Ceramida (Elaphocera) spp. (Coleoptera: Scarabaeidae) plaga de los olivares de la provincia de Sevilla. Bol. San. Veg. Plagas 22, 203-211.

Shapiro, A. M.; Porter, A. H., 1989: The lock-and-key hypothesis: evolutionary and biosystematic interpretation of insect genitalia. Annu. Rev. Entomol. 34, 231-235.

Thorpe, R. S.; McGregor, D. P.; Cumming, A. M., 1993: Molecular phylogeny of the Canary Island lacertids Gallotia: mitochondrial DNA restriction fragment divergence in relation to sequence divergence and geological time. J. Evol. Biol. 6, 725-735.

Zamotailov, A. S., 1988: O polovij attraktantaj y polovom poviedenii u plastinchatousij. Vest. Zool. 6, 61-64.

Zunino, M., 1984a: Sistematica generica dei Geotrupinae (Coleoptera, Scarabaeoidea: Geotrupidae). Boll. Mus. Reg. Sci. Nat. Torino 2, 445- 464.

Zunino, M., 1984b: Essai préliminaire sur l'evolution des armures génitales des Scarabaeinae, par rapport à la taxonomie du groupe et à l'évolution du comportement de nidification. Bull. Société Entomologique France 88, 531-542.

Zunino, M., 1987: La evolución de los aparatos copuladores: comentarios a W. G. Eberhard. 'Sexual Selection and Animal Genitalia'. Elytron 1, 105-107.

Zunino, M.; Monteresino, E., 1990: Ideas preliminares sobre la evolución de los aparatos copuladores en Rutelinae (Col. Scarabaeoidea) y filogenia del grupo. Rev. Soc. Ent. Argentina 48, 3-13.

Zunino, M.; Palestrini, C., 1988: L'evoluzione differenziale dei caratteri de il riconoscimento delle specie nei Coleotteri Scarabeidei. Il problema biologico della specie. In: (eds), Problemi Di Biología E Di Storia Della Natura, Vol. 1. Mucchi. Modena, Italy: Collana UZI. pp. 173-176.

Authors' addresses: I. Sanmartín, Department of Systematic Zoology, Evolutionary Biology Centre, Uppsala University, Norbyvägen 18D, SE-752 36 Uppsala, Sweden; F. Martín-Piera, Departamento de Biodiversidad y Biología Evolutiva (Entomología), Museo Nacional Ciencias Naturales, Jose Gutiérrez Abascal 2, 28006-Madrid, C.S.I.C. Spain. E-mail: isabel.sanmartin@ebc.uu.se

\section{Appendix}

List of material studied for the phylogeny of the Palaearctic Pachydeminae. For each genus, the number of species studied, the percentage with respect to the total number of species and the distribution of the genus are indicated. The total number of species was obtained from the references indicated between parentheses
Genus Tanyproctus

Faldermann, 1835

Species studied

T. bucharicus (Reitter, 1897)

T. confinis Motschulsky, 1859

T. eversmanni Reitter, 1902

T. ganglbaueri (Brenske, 1897)

T. iranicus Petrovitz, 1968

T. jordanicus Baraud, 1990

T. kindermanni (Reiche, 1861)

T. ovatus Motschulsky, 1859

T. pamphilus Petrovitz, 1967

T. persicus (Ménétries, 1832)

T. reichei (Rambur, 1843)

T. rufidens (Marseul, 1879)

T. rugulosus Fairmaire, 1892

T. riparius Petrovitz, 1963

T. satanas Reitter, 1902

T. saulcyi (Reiche, 1856)

T. speculator Petrovitz, 1963

T. subciliatus Reitter, 1902

T. verryi Fairmaire, 1884

No. species studied

Total species (Lacroix 2000)

Distribution:

Transcaucasus

$\%$ Total

19

90 (Approx.)

From Greece and Tunis to China (Middle East, Caucasus,

Iran, Afghanistan) $21 \%$

\begin{tabular}{ll}
\hline $\begin{array}{l}\text { Genus Hemictenius } \\
\text { Reitter, } 1897\end{array}$ & Species studied \\
\hline & H. gracilipes (Semenov, 1890) \\
& H. latitarsis (Reitter, 1891) \\
& H. lebedevi Reitter, 1908 \\
& H. magnitarsis Reitter, 1897 \\
& H. nigrociliatus Reitter, 1897 \\
& H. opacipes Reitter, 1902 \\
& H. opacus (Ball., 1870) \\
& H. ochripennis Reitter, 1902 \\
& H. simplicitarsis Reitter, 1897 \\
& H. tekkensis (Reitter, 1889)* \\
& 10 \\
No. species studied & 25 \\
Total species & \\
(Nikolajev 1987, 2000) & Central Asia \\
Distribution: & $40 \%$ \\
\hline Total &
\end{tabular}

* This species is currently included in Asiactenius Nikolajev, 2000. 


\begin{tabular}{|c|c|}
\hline $\begin{array}{l}\text { Genus Pachydema } \\
\text { Castelnau, } 1832\end{array}$ & Species studied \\
\hline & 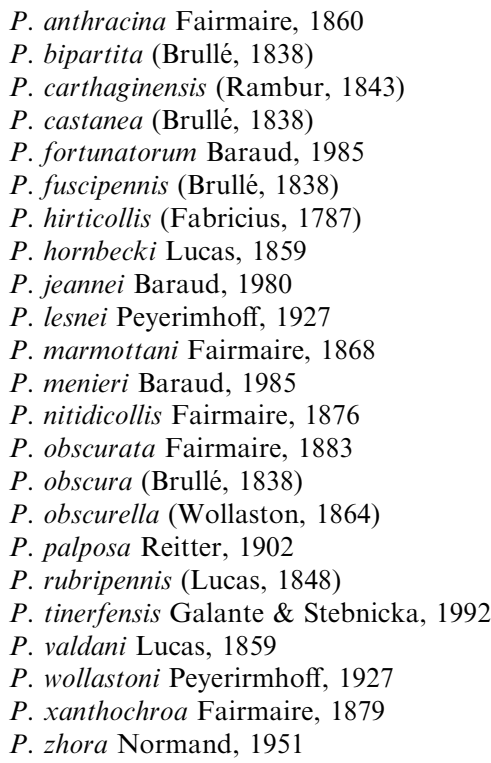 \\
\hline No.species studied & 23 \\
\hline $\begin{array}{l}\text { Total species } \\
\text { (Baraud 1985, 1994; } \\
\text { López-Colón 1999; } \\
\text { Lacroix 2000) }\end{array}$ & 98 \\
\hline Distribution & $\begin{array}{l}\text { Canary Islands, North Africa } \\
\text { (from Morocco to Middle East) }\end{array}$ \\
\hline$\%$ Total & $23.5 \%$ \\
\hline
\end{tabular}

\begin{tabular}{ll}
\hline $\begin{array}{l}\text { Genus Ceramida } \\
\text { Baraud, } 1987\end{array}$ & Species studied \\
\hline & Ceramida adusta (Kraatz, 1882) \\
& Ceramida baraudi (Branco, 1981) \\
& Ceramida bedeaui (Erichson, 1840) \\
& Ceramida brancoi (Baraud, 1975) \\
& Ceramida brandeiroi (Flach, 1906) \\
& Ceramida cobosi (Báguena, 1955) \\
& Ceramida dinizi (Branco, 1981) \\
& Ceramida longitarsis (Illiger, 1803) \\
& Ceramida malacensis (Rambur, 1843) \\
& Ceramida mauritanica (Rambur, 1843) \\
& Ceramida moelleri (Flach, 1906) \\
& 11 \\
No. species studied & 11 \\
Total species (Sanmartín \& & \\
Martín-Piera 1999b) & Iberian Peninsula, Morocco, Algeria \\
Distribution & $100 \%$ \\
\hline Total &
\end{tabular}

\begin{tabular}{|c|c|}
\hline $\begin{array}{l}\text { Genus Elaphocera } \\
\text { Gené, } 1836\end{array}$ & Species studied \\
\hline & 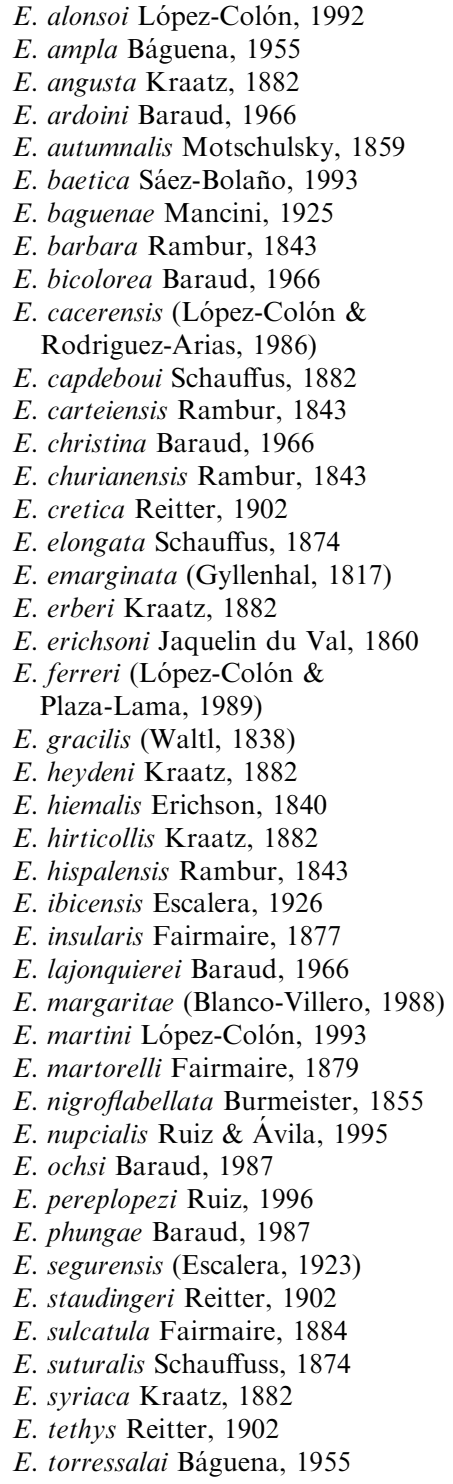 \\
\hline No. species studied & 43 \\
\hline $\begin{array}{l}\text { Total species (Baraud 1992, } \\
\text { Sanmartín \& } \\
\text { Martín-Piera 1999a) }\end{array}$ & 43 \\
\hline Distribution & $\begin{array}{l}\text { Mediterranean (From Greece-Middle } \\
\text { East to Spain), North Africa } \\
\text { (Morocco, Algeria) }\end{array}$ \\
\hline$\%$ Total & $100 \%$ \\
\hline
\end{tabular}




\begin{tabular}{|c|c|c|c|c|}
\hline Genus & Species studied & Distribution & Total species & $\%$ Total \\
\hline Europtron Marseul, 1867 & $\begin{array}{l}\text { E. confusum Marseul, } 1878 \\
\text { E. gracile Marseul, } 1867\end{array}$ & Algeria, Morocco & 3 (Bezdek et al. 1999) & $66.7 \%$ \\
\hline Peritryssus Reitter, 1918 & P. excisus Reitter, 1918 & Sicilia & 1 (Baraud 1992) & $100 \%$ \\
\hline Brenskiella Berg, 1898 & B. flavomicans (Brenske, 1896) & Israel & 1 (Baraud 1992) & $100 \%$ \\
\hline Alaia Petrovitz, 1980 & A. sexdentata Petrovitz, 1980 & Iran, Afghanistan & 1 (Petrovitz 1980) & $100 \%$ \\
\hline Tanyproctoides Petrovitz, 1971 & T. arabicus (Arrow, 1932) & Saudi Arabia, Kuwait & 1 (Petrovitz 1971) & $100 \%$ \\
\hline Atanyproctus Petrovitz, 1954 & $\begin{array}{l}\text { A. afghanus Petrovitz, } 1968 \\
\text { A. ernae Petrovitz, } 1980 \\
\text { A. miksici Petrovitz, } 1965 \\
\text { A. simplicitarsis Petrovitz, } 1954\end{array}$ & Afghanistan, Iran & 6 (Petrovitz 1980) & $67 \%$ \\
\hline Otoclinius Brenske, 1896 & $\begin{array}{l}\text { O. fragilis Petrovitz, } 1980 \\
\text { O. gracilipes Brenske, } 1896 \\
\text { O. loebli Baraud, } 1991 \\
\text { O. schauffelei Petrovitz, } 1958\end{array}$ & Iran & 5 (Baraud 1991) & $80 \%$ \\
\hline Pachydemocera Reitter, 1902 & P. lucidicollis (Kraatz, 1882) & Rhodes, Syria & 1 (Baraud 1992) & $100 \%$ \\
\hline Leptochristina Baraud \& Branco, 1991 & $\begin{array}{l}\text { L. annamariae Baraud \& } \\
\quad \text { Branco, } 1991 \\
\text { L. pubicavula (Reitter, 1902) } \\
\text { L. pubimargo (Reitter, 1902) } \\
\text { L. variabilis (Petrovitz, 1962) }\end{array}$ & $\begin{array}{l}\text { Syria, Turkey, } \\
\text { Iraq, Israel }\end{array}$ & $\begin{array}{l}4 \text { (Baraud and Branco } \\
\text { 1991) }\end{array}$ & $100 \%$ \\
\hline Pseudopachydema Balthasar, 1930 & P. caucasica Balthasar, 1930* & Azerbaïdjan, Caucase & 1 (Baraud 1992) & $100 \%$ \\
\hline $\begin{array}{l}\text { Kryzhanovskia Nikolajev \& Kabakov, } \\
1977\end{array}$ & $\begin{array}{l}\text { K. olegi Nikolajev \& } \\
\text { Kabakov, } 1977^{*}\end{array}$ & Afghanistan & $\begin{array}{l}1 \text { (Nikolajev and } \\
\text { Kabakov 1977) }\end{array}$ & $100 \%$ \\
\hline
\end{tabular}

* Coded from the original description.

Palearctic genera not included in this study (Lacroix 2000): Phalangonyx Reitter, 1889, Jalalabadia Balthasar, 1967, Buettikeria Sabatinelli \& Pontuale, 1998, Asiactenius Nikolajev, 2000 (see text). 